Historic, Archive Document

Do not assume content reflects current scientific knowledge, policies, or practices. 



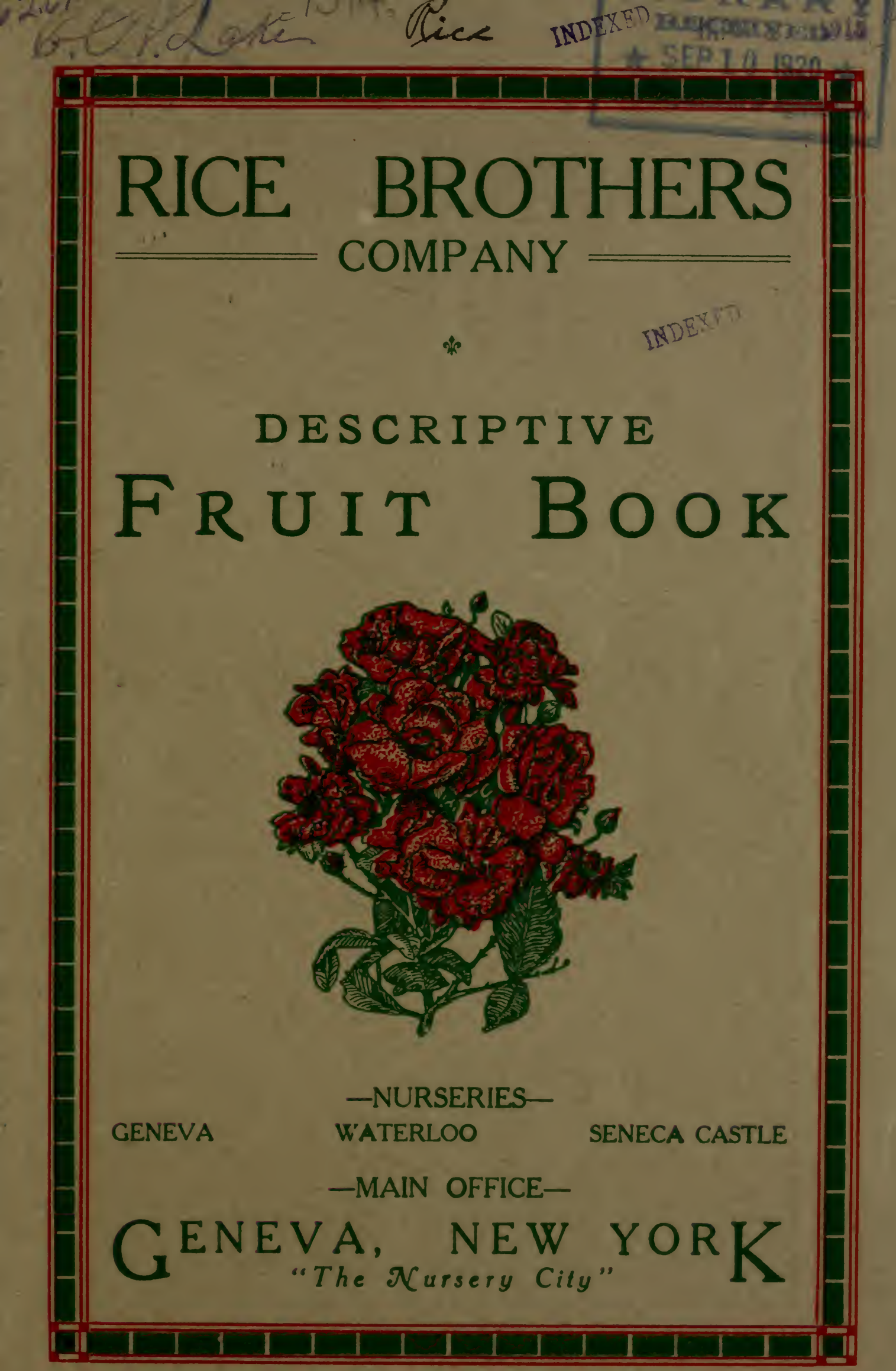




\section{TO OUR SALESMEN}

TT IS QUITE IMPORTANT that you sell ONLY varieties 1 named in this book; it covers everything we grow (and we grow everything that is worth growing). We do not want to buy from others, which we shall be obliged to do if varieties not named are sold. The customer, you and ourselves will be better satisfied in the end if you confine your efforts to the sale of STOCK WE PRODUCE OURSELVES.

We grow 68 varieties of Apple, 10 varieties of Crab Apple, 20 varieties of Standard Pears, 8 varieties of Dwarf Pears, 23 varieties of Sweet and Sour Cherries, 29 varieties of Plums, and 38 varieties of Peaches. Besides we have a large assortment of Apricots, Quinces, Grape Vines, Currants (bush and tree form), Gooseberries, Raspberries, Blackberries, Rhubarb, Asparagus, Ornamental Trees, Evergreens, Hedge Plants, Upright Shrubs, Evergreen Shrubs, Roses (all the leading varieties, old and new), Bulbs, Bulbous Plants and Perennials, all being fully described in the following pages, being arranged in the same order in both price list and catalogue.

We have stopped selling the $X$ grade stock, as we find IT DOES NOT GIVE SATISFACTION at time of delivery. The place for trees of this size is on the brush pile.

\section{J. P. RICE, President.}

\section{IMPORTANT}

We are not connected with any other individual or firm of similar name engaged in the Nursery business. Rice Brothers Company is the old, original firm established by John Rice Sr., over thirty years ago. 
ILLUSTRATED AND DESCRIPTIVE

цsт of FRUIT Ан....

ORNAMENTAL TREES

SHRUBS ROSES

HERBACEOUS PLANTS

BULBS

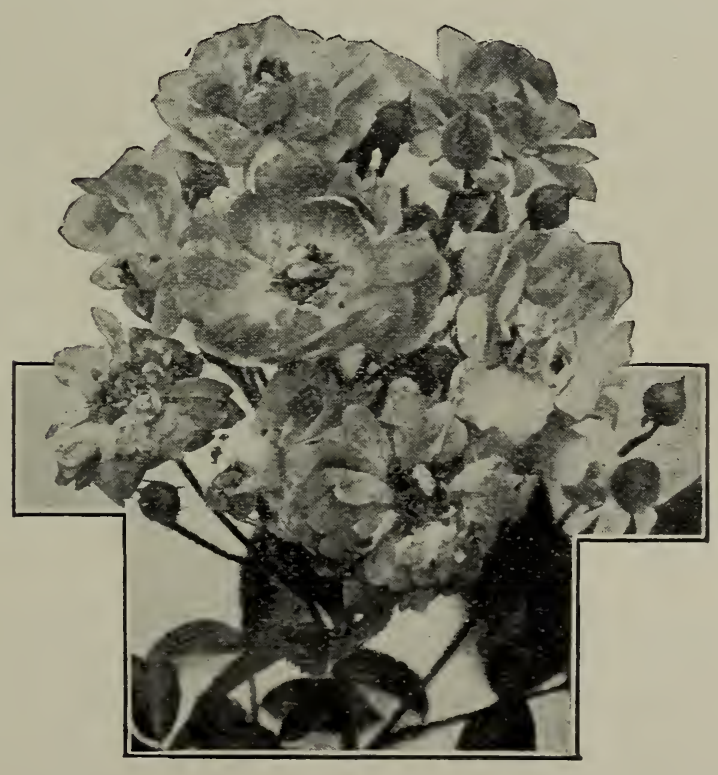

Rice Brothers Co. GROWERS AND IMPORTERS
GENEVA
- -
NEW YORK 
W E TAKE PLEASURE in presenting our descriptive catalogue. Herein we show the results of thirty years' experience, and we have endeavored to name only such varieties as have been thoroughly tested and proven. Western New York is pre-eminently suited for the growing of healthy, hardy, long-lived trees. This is especially so as regards the section about Geneva; the climatic conditions here being strongly influenced by its proximity to Seneca Lake.

Our Nurseries in the growing season present a beautiful and interesting sight. We shall be pleased at any time to welcome our patrons or friends and show them both our Nurseries and Packing Houses.

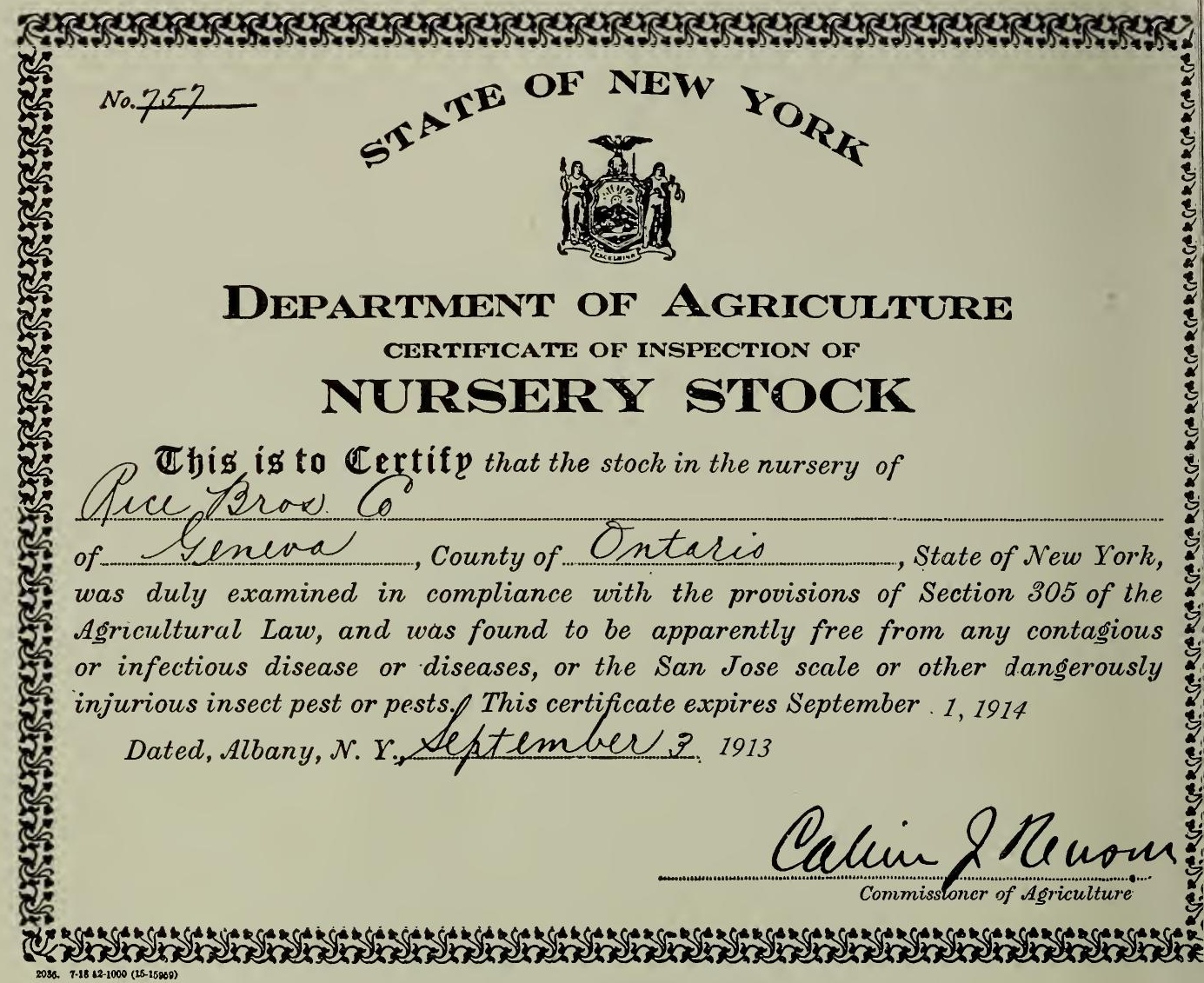
OUR GUARANTEE

Our stock is tree from disease, scale, or other insect pests. Every season we have a representative of the Department of Agriculture of the State of New York make a careful inspection of our Nursery, and we are furnished annually with a certificate stating that it is apparently free in all respects from contagious or infectious disease or diseases, San Jose scale, or other injurious insect pest or pests.

As an additional precaution, we have buit in our shipping department scientifically-constructed fumigating houses, so that we may fumigate with hydrocyanic acid gas if desired.

To repeat: We offer through our salesmen and accept orders for only the varieties that we can furnish, so we can guarantee our stock as furnished to be true to label. Should any item, through a mistake, prove not true to label, other stock will be furnished, without expense to the purchaser, and we are not liable for any other damages. 


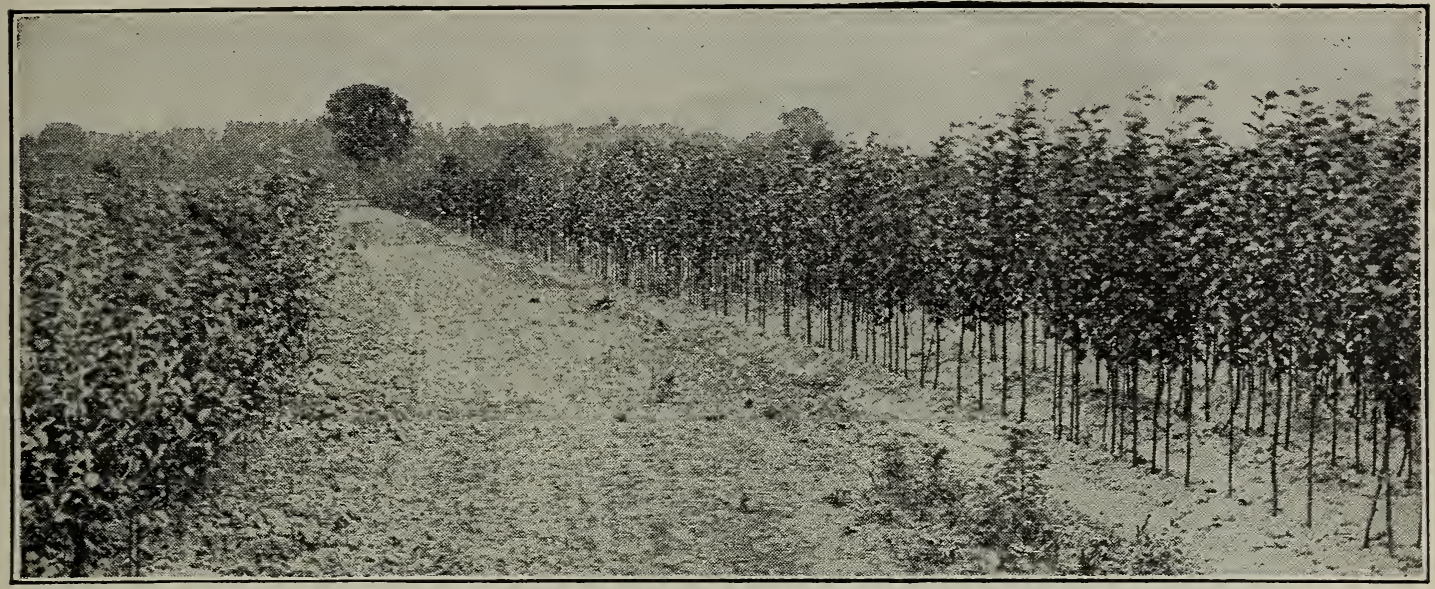

\section{FRUIT DEPARTMENT}

The period of ripening given on all fruit herein, unless otherwise noted, is the time they mature in Western New York, and will be found to vary North and South. Following the descriptions, we give lists of those most valuable for particular sections.

\section{APPLES}

Our principal stock of apples consists of the following varieties, which have been well tested, and can be recommended as the best now in cultivation.

Our apple trees are two or three years from bud when delivered to our customers. They are grown on imported French seedlings, which cost us about double the price of American seedlings. By using French seedlings we cau insure our customers well developed bodies and well developed roots.

\section{SUMMER VARIETIES}

Early Harvest. Medium size, roundish; skin, light yellow; flesh, white, tender, juicy; pleasant sub-acid. July and August.

Early Strawberry. Medium, striped with deep red; tender, sub-acid, and excellent; erect grower and productive; good for both garden and orchard. Last of August.

Golden Sweet. Large, round, light straw color; medium quality; tree in the nursery a crooked grower. August and September.

Red Astrachan. Large, roundish; nearly covered with deep crimson, with a pale white bloon1; very beautiful; flesh, white, crisp, 1noderately juicy, with an acid flavor; good for cooking. Tree vigorous, hardy, and a good bearer. August.

Sweat Bough. Large, oblong; skin pale yellow; flesh white, tender and crisp when fully ripe, with a rich, sweet and sprightly flavor. August and September.

Yellow Transparent. Tree is a good grower, hardy and an unusually early bearer. Fruit pale yellow, roundish ovate, good size and good quality; skin clear white at first, becoming a beautiful pale yellow when fully matured. Farly in August. 


\section{AUTUMN VARIETIES}

Alexander. A Russian apple. Large; deep red or crimson; flesh yellowish white, crisp, tender, with pleasant flavor. Tree a moderate grower. Very hardy.

Duchess of Oldenburg. Good size, yellow, streaked red; juicy, rich, sub-acid; productive.

Fall Pippin. Very large, roundish, or somewhat flattened; greenish yellow, with sometinies a blush; flesh very tender. October and November.

Fameuse. (Snow.) Medium to large size, roundish; deep crimson, flesh very white, tender, juicy and of the best quality. Tree hardy and productive. Oct. and Nov.

Gravenstein. Large, round; greenish yellow, striped with red; flesh tender, juicy, and crisp, with a slight aromatic flavor. September and October.

Longfield. Tree an early and abundant bearer. Firuit medium, conical; color a yellowish green, thickly covered with red stripes, and a decided blush on the sunny side; flavor a rich, sprightly sub-acid. October and November.

Maiden's Blush. Medium to large; flat, smootli; evenly shaded red cheek or blush on a pale yellow ground; flesh tender, sub-acid. September and October.

Rambo. Fruit medium size, flat; skin yellowish white, streaked and mottled with red; flesh whitish, very tender, fine flavored. October and November.

Smoke House. Large, yellow, richly shaded with bright red; firm, juicy, crisp, and rich. Tree a very crooked grower. October and November.

Twenty Ounce. Very large, nearly round; yellow, striped with red; of fair quality; tree a vigorous, spreading grower and a finebearer. Excellent for baking. Very popular in the markets. October to January.
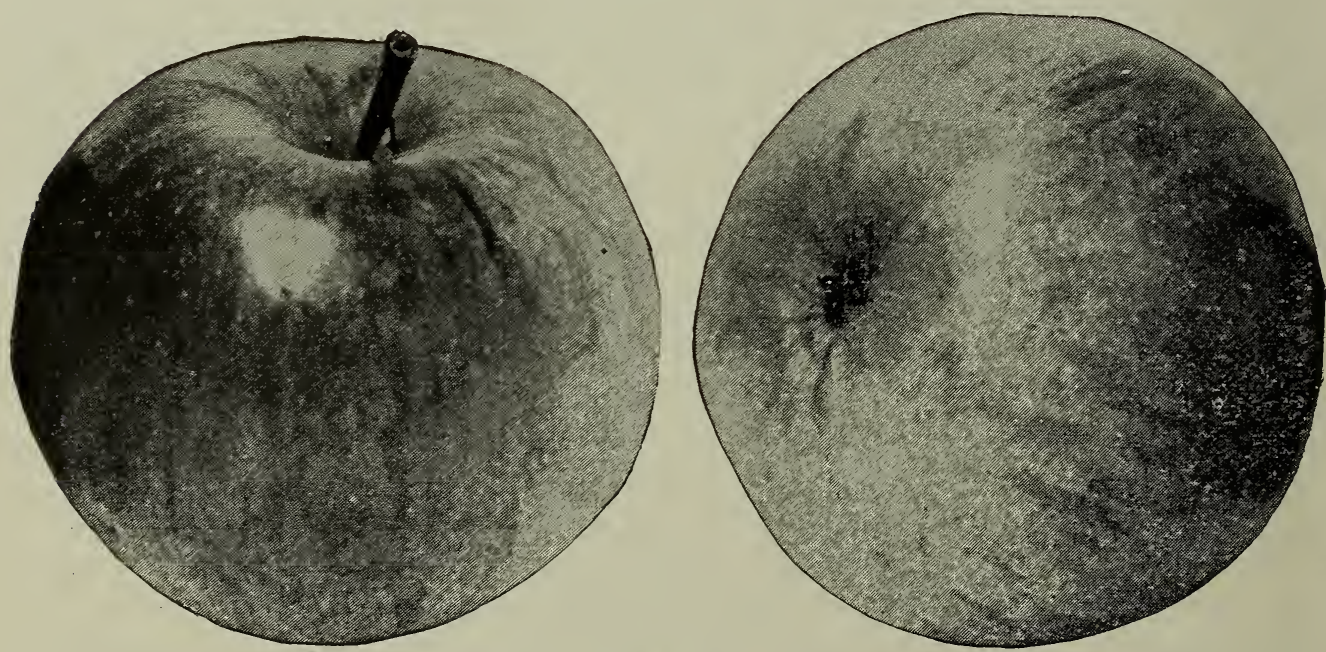

Wealthy

Wealthy. Fruit medium to large; light color, striped with red; pleasant sub-acid, flesh white. Tree a good grower and early bearer; hardy. Oct. and Nov. 


\section{WINTER VARIETIES}

Arkansas Red. Size large; color beatififul light crimson in the shade, darker in the sun, with indistinct splashes and stripes over the whole surface of dark crimson; flesh fine grained, whitish, tinged with red and yellow. January to Marcli.

Baldwin. Large, roundish; deep bright red; juicy, crisp, subacid. Tree vigorous, upright and very productive. Very popular in most of the Northern States and Canada. January to A pril.

Baxter. Originated in Canada, on the banks of the St. Lawrence. Above medium size; dark red, spotted; mild, sub-acid, quality good.

Ben Davis. Originated in Ken-

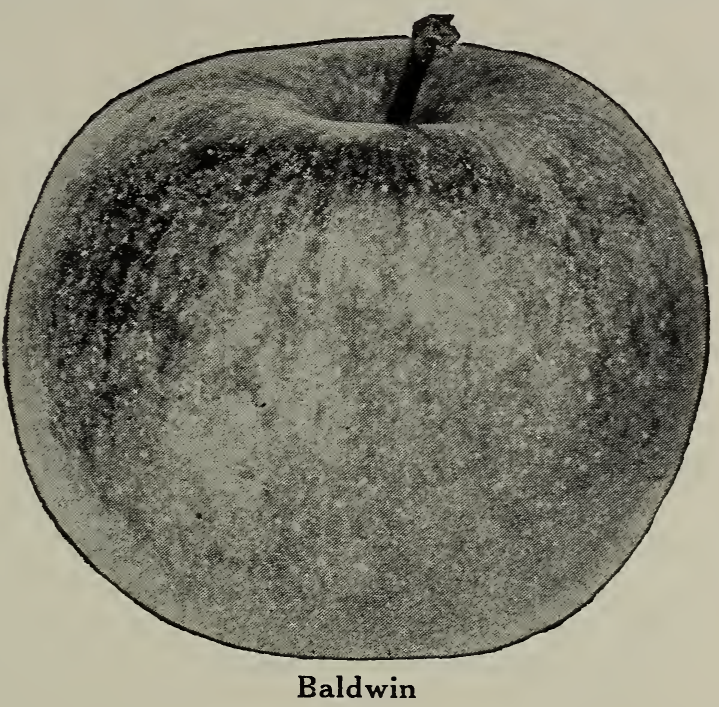
tucky. Tree remarkably healthy, vigorous, and an abundant bearer. Fruit large, handsome, striped; flesh whitish, tender, juicy, sub-acid; a very profitable market variety. Keeps till midwinter or later. December to March.

Bismarck. Very large, remarkably handsome and showy; color red on yellow ground; flesh yellow; quality good; extremely hardy and prolific and bears very early. November.

Delicious. Esteemed as a long keeper and valuable market fruit. Fruit large, roundish; skin greenish yellow, much slraded with light and dark red and sprinkled with brown dots; flesh yellowish, juicy, mild sub-acid. January to May.

Fallawater. Large, roundish, slightly conical, smooth; skin yellowish green, with a dull red cheek; flesh greenish white, with a mild, slightly sub-acid flavor. Tree a strong grower and good bearer. November to January.

Gano. Large; deep red, sliaded mahogany; flesh fin grained, tender, pleasant and mild, sub-acid. Tree vigorous and healthy. February to May.

Gideon. Tree as hardy as a Crab, vigorous, and an early and prolific bearer, Fruit medium to large; color a rich golden yellow, with a clear and handsome blush on the sunny side; flesh fine, juicy, sub-acid. November to January.

Go!den Russet. Medium size; yellowish nearly covered with russet, with sometimes a little red on the sunny side: flesh firm, sometines a little tough, but with a very pleasant, scarcely acid flavor. January to June.

Grimes' Golden. Good size, round or slightly conical; rich golden yellow, sprinkled with light gray dots, sometimes sliglitly russeted; flesh yellow, crisp, tender, rich and juicy, with a sprightly sub-acicl flavor. December to February.

Hubbardston Nonesuch. Large, a little oblong; yellowish ground, nearly coverèd with bright red stripes and dots. One of the best. November to January.

Hendrick Sweet. Fruit medium to large, roundish ovate; color red splashed with crimson; flesh tender, juicy, very sweet, rich. November to Marcli.

Jonathan. Medium size; red and yellow; flesh tender, juicy and rich; very productive. One of the best varieties either for table or n11arket. November to March. 
King. (Tompkins County.) Large and handsome, striped red and yellow. Tree vigorous. November to January.

McIntosh Red. Originated in Canada. Fruit above medium size; skin whitish-yellow nearly covered with dark, rich red or crimson; flesh white, very tender, juicy, mild sub-acid. November to January.

Mammoth Black Twig. The fruit resembles Winesap, but is larger and superior in flavor and a better keeper; color bright red, texture fine. Tree a strong grower, bears early and abundantly, holding its load well. February to May.

North Star. The North Star apple since its introduction has had a large sale, altogether on its merits as an American Ironclad. It is a seedling of Duchess of Oldenturg, but of better quality. Originating in Maine is a guarantee of its hardiness. We consider it an all-around first class apple, a coming standard variety.

Northern Spy. Large, roundisl, slightly conical, somewhat ribbed; striped, with the sunny side nearly covered with purplish red; flesh white and tender with a mild sub-acid, rich and delicious flavor. January to May.

Northwestern Greening. Large, often green, but yellow when fully ripe; flesh yellow, rather coarse, juicy and sub-acid, quality good. January to May.

Ontario. Originated in Canada. Said to be a seedling from the Wagener and Northern Spy. Tree moderately vigorous with spreading head and very hardy; foliage large, dark green; fruit large, roundish, somewliat ribbed, striped on the sunny side with beautiful red; quality fine, crisp and juicy, and a good keeper. An annual and abundant bearer. December to A pril.

Opalescent. A new apple from Southern Ohio; fruit of the largest size; slightly oblong; color deep, dark red with yellowish dots; flesh exceeding tender, white, moderately juicy and of the highest flavor. Tree a regular grower, hardy, healthy and productive. Season, late winter and early spring.

Perfect. We control this variety and consider it a remarkably fine one. The blow end suggests the Baldwin, but the flavor is more like the Spy. For density, weight and suitable skin there is no better variety for shipping. We certainly advise growers to plant the Perfect exclusively. December to June.

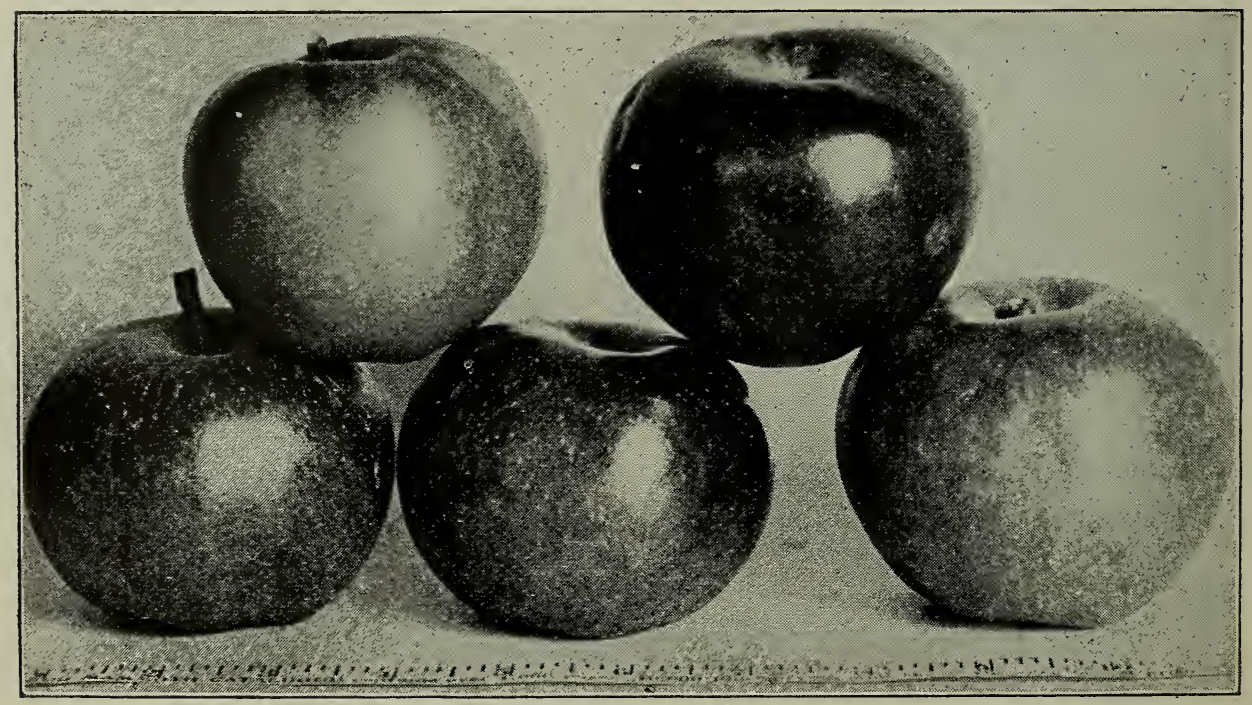

The Perfect, grown in Maine. Greatly reduced in size. 
Rhode Island Greening. Fruit large, roundish; skin green becoming a greenish yellow, with a dull blush when ripe; flesh yellow, fine grained, tender, with a rich, rather acid flavor. Tree vigorous, spreading and productive. Young trees in the nursery more or less crooked. November to March.

Rome Beauty. Large, roundish; yellow, shaded and striped with bright red; sprinkled with light dots; flesh yellowish, tender, juicy, sprightly, sub-acid; quality good. November and December.

Roxbury Russet. Fruit large size, roundish, a little flattened; skin dull green nearly covered with russet; flesh moderately juicy, with a pleasant sub-acid flavor. Tree vigorous, but rather crooked. January to June.

Seek-no-Further. Fruit medium size, conical; skin a dull red, striped and russeted; flesh white and fine grained, with a rich flavor. November to February.

Spitzenburg. (Esopus.) Medium size; deep red covered with gray dots; flesh ye1low, rather firm, crisp and juicy, with a delicious flavor. The tree is a poor grower in the nursery. December to March.

Stark. Originated in Ohio. Fruit iarge, roundish, inclined to conic; skin greenish yellow, striped with light and dark red and thinly sprinkled with light and brown dots; flesh yellowish, moderately juicy, mild sub-acid. An early and abundant bearer. January to May.

Stayman's Winesap. Large, bright red, striped; excellent quality; flesh firm, tender, rich, juicy, mild sub-acid. A strong grower and heavy bearer. Superior to old Winesap. Succeeds in a great variety of soils. February to April.

Sutton Beauty. Fruit large, roundish; skin waxen yellow, striped with a crimson; flesh tender, sub-acid, good. Tree a free grower and productive; a valuable apple. December and January.

Tolman Sweet. Medium size, pale whitish yellow, with a soft blush on one side and generally a line running from stem to calyx; flesh quite white, rather firm, fine grained, with a rich sweet flavor. December to April.

Wagener. Fruit medium to large size, flattened; skin light yellow, shaded with red; flesh firm, sub-acid, with an excellent flavor. Tree thrifty, very upright and early bearer. Fruit improved by thinning. December to March.

Winesap. Fruit medium size, rather oblong; skin smooth, of a dark red with a few streaks; flesh yellow, firm, crisp. Tree a poor grower in the nursery. December to April.

Winter Banana. Large; clear, pale yellow, witlı beautiful pinkish red blush; good for dessert. Bears young.

Wolf River. Skin yellow, almost covered witlı crimson; fleslı white, juicy, tender, with a peculiar, pleasant, mild sub-acid flavor. Tree a strong, stout grower, a great bearer and very liardy. January and February.

Yellow Bellflower. Fruit large oblong, irregular; skin pale lemon yellow, sometimes with a blush; flesh tender, juicy, with a sprightly acid flavor. November to February.

York Imperial. (Johnson's Fine Winter.) A native of York County, Pa. Medium to large; white, heavily shaded witlı dark crimson; fleslı firm, crisp, juicy and sub-acid. Tree an early and abundant bearer. December to February. 


\section{EXTRA HARDY APPLES}

In the Northern States it is necessary to plant extra hardy varieties of apples, in order to make their cultivation a success. Years ago there were but one or two sorts which could be grown in the extreme north with any degree of satisfaction to the planter. Now, however, we have quite a list of Russian varieties and Northern seedlings, which will thrive and bear abundantly in any section where we send salesmen.

Duchess of Oldenburg...... September Gideon.......... November ıo January Longfield ...........January to March McIntosh Red... November to January-

Wealthy .... November and December Wolf River.....J Jinuary and February Yellow Transparent. .July and August

\section{HARDY APPLES}

The following list of varieties we rate as hardy, in comparison with the Baldwin. They will grow in sections like that along the St. Lawrence River and Central Maine, New Hampshire and Vermont, where the Baldwin either winter kills outright or leads a very precarious existence. We include in the list the "Extra Hardy" varieties, which are equally valuable for all sections:

Yellow Transparent....... Last of July

Red Astrachan...............August

Golden Sweet.. August and September Duchess of Oldenburg...... September Fameuse ....... October to December Gideon........ November to January McIntosh Red... November to January Grimes' ('olden. December to February Tolman Sweet...... December to April Opalescent ........ January to iIarch

\section{CRAB APPLES}

As an ornamental fruit, and for jellies and preserving, the crab apple is unequalled. All are very hardy and prolific, come into bearing when very young, and command a ready and profitable market. We name the best sorts:

General Grant. I Aarge, round; yellow covered with stripes of $r \in d$, and when exposed to the sun, turning quite dark; flesh white, fine grained. A good grower, hardy and productive.

Hyslop's. Almost as large as the Early Strawberry apple; deep crimson. Very popular in the West on account of its large size, beauty and hardiness. Tree remarkably vigorous. October.

Transcendent. A beautiful variety of the Siberian Crab; red and yellow. Tree a remarkably strong grower. September.

Whitney. Large, averaging one and a half to two inches in diameter; skin smooth, glossy green, striped, splashed with carmine; flesh firm, juicy, and flavor very pleasant.
Wolf River..... January and February Longfield......... January to March Northern Spy ....... January to May Stark............ January to May Golden Russet........January to June Perfect............. January to June

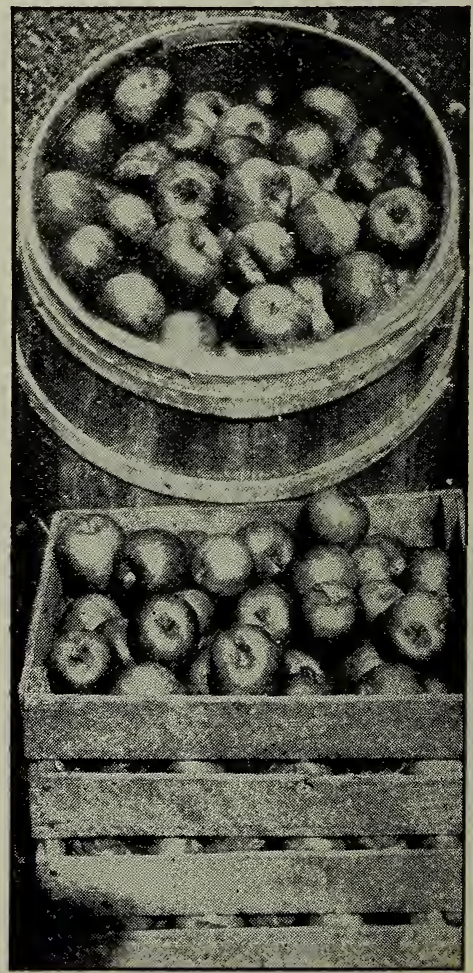

Winter Banana 


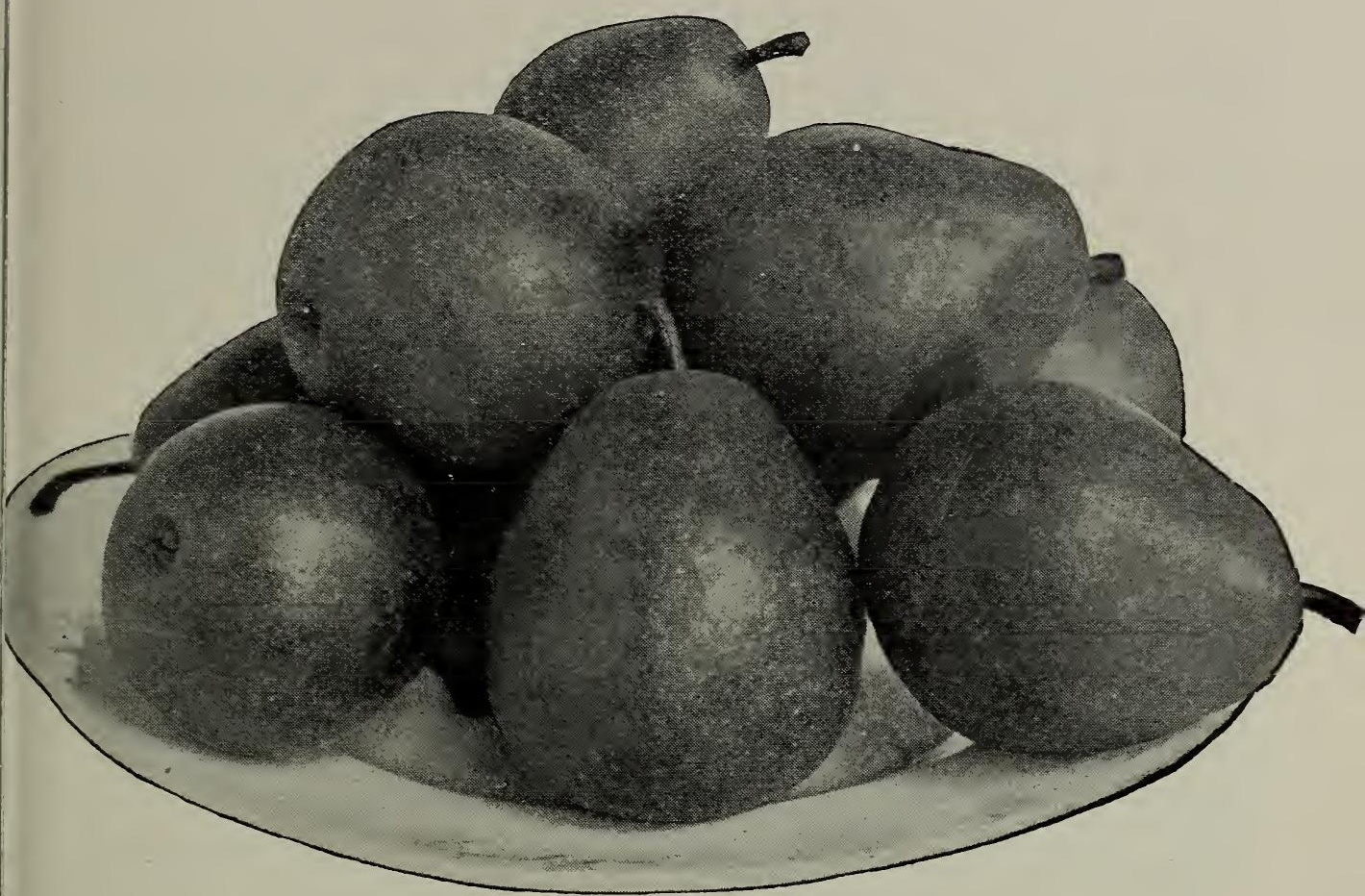

Plate of Buerre Anjou

\section{PEARS}

Our soil at Geneva is particularly adapted to the growth of the pear, and we can recommend our trees as being healthy and vigorous.

\section{RIPENING PEARS}

Pears require to be gathered from the trees and ripened in the house; if allowed to ripen on the trees, they are nearly worthless.

Summer and autumn pears should ba gathered as soon as the earliest and premature specimens are observed to ripen; gather the best matured specimens first, and a short time afterwards the remainder of the crop; keep them in clean boxes or drawers until ripe; if you wish to retard the ripening keep them in a corl place.

Winter pears should be allowed to hang late upon the trees, then gathered and treated the same as winter apples, that is, barrel them and keep in a cool cellar until they mature. After they commence to ripen, they may be kept for a few days in a warm room to good advantage.

Pears are cultivated as standards, worked upon seedling pear stock; and as dwarf, worked upon French quince stock.

Standard pears thrive, with good care, on most any soil moderately rich, but well drained heavy loam is best.

Dwarf pears require rich land and annual pruning to give the best results. 


\section{SUMMER VARIETIES}

Bartlett. Large size, irregular in for111; clear yellow with a bluslı on the sunny side; very juicy, buttery and high flavored. August and September.

Clapp's Favorite. Large; pale lemon yellow with brown dots; fine texture, melting, buttery, juicy, with a ricl, sweet, delicate vinous flavor. Middle of August.

Koonce. Medium to large, pyriform, very handsome; yellow, one side covered with bright carmine, sprinkled with brown dots; flesh juicy, sweet, spicy, good. Ripens with the earliest. Tree a renarkably strong grower, hardy and very productive. Middle of August.

\section{AUTUMN VARIETIES}

Beurre Bosc. Large, yellow, russeted, lialf melting, high flavored and excellent. Tree a poor, crooked grower in the nursery, and but little cultivated. October.

Duchesse d'Angouleme. A magnificent pear when well grown upon quince stock. Fruit of the largest size, with an irregular, uneven surface; skin greenish-yellow spotted with russet; flesh white, very juicy. October.

Flemish Beauty. Large size, greenish-yellow and brown, with large spots of russet; rich and juicy, with a melting and musky flavor. Fruit often cracks badly. September and October.

Garber. One of the Japan Hybrids; earlier and larger than Keiffer; hardy, productive, early bearer; excellent for canning. September and October.

Seckel. A most delicious little pear, unsurpassed in flavor. Fruit small, irregularly formed, roundish, obvate; skin yellowish brown with a red cheek; flesh very rich, spicy and sweet. Septeniber and October.

Sheldon. Fruit rather large, roundish; skin greenish russet with a red cheek; flesh melting, rich, juicy, and perfumed; first rate. October.

Vermont Beauty. Fruit of med i u m size, roundish; skin yellow, nearly covered with carmine; flesh melting, sprightly; very good. Tree healthy, hardy and very produetive. October.

Worden Seckel. A seedling of Seckel. Fruit medium size, borne in clusters, juicy, buttery, fine grained, with a flavor and aroma fully equal to that of its parent, which it surpasses in size, beauty and keeping qualities. Ripens in October, but will keep in good condition till December.

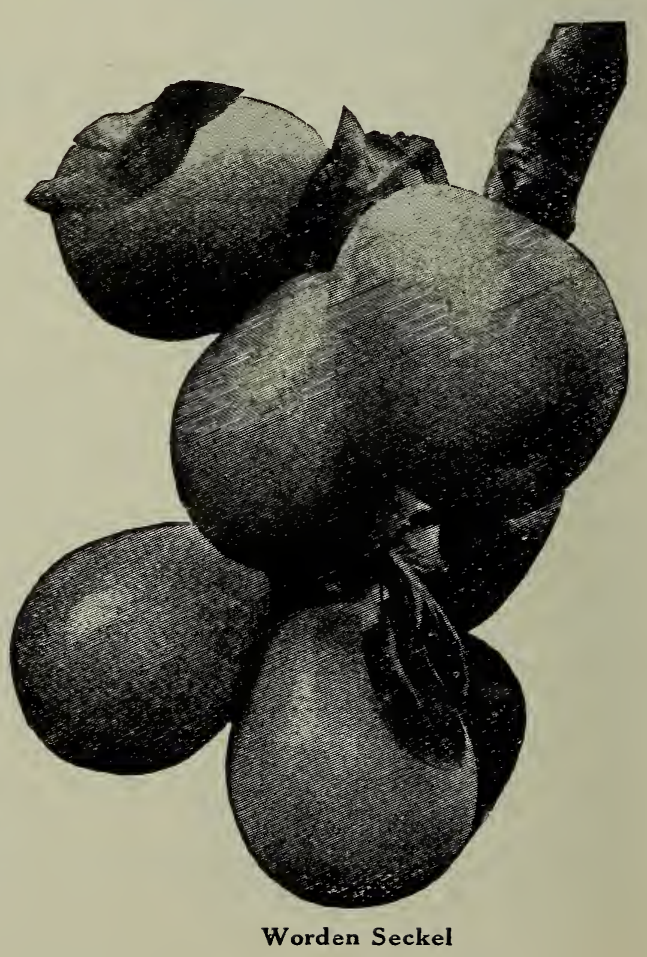




\section{LATE AUTUMN AND WINTER VARIETIES}

Beurre d'Anjou. Large size, pyriform; light green with russet and red cheek; rich, melting and of excellent flavor. October and November.

Beurre Clairgeau. Very large, pyriform; yellow and red; texture of Beurre Bosc; flesh yellowish, nearly melting. Tree a fair grower and an early abundant bearer. A magnificent market fruit. October and November.

Kieffer. Tree remarkably vigorous, having large, dark green, glossy leaves, and is an early and prolific bearer. Fruit large to very large, roundish, oval, narrowing at both ends; skin deep yellow with a fine blush on the sunny side; flesh whitish, a little coarse, juicy; very good. Ripens through October and November.

Lawrence. An American pear of great excellence. Fruit nedium size, obtuse, pyriform; skin fine yellow; flesh juicy, sweet and

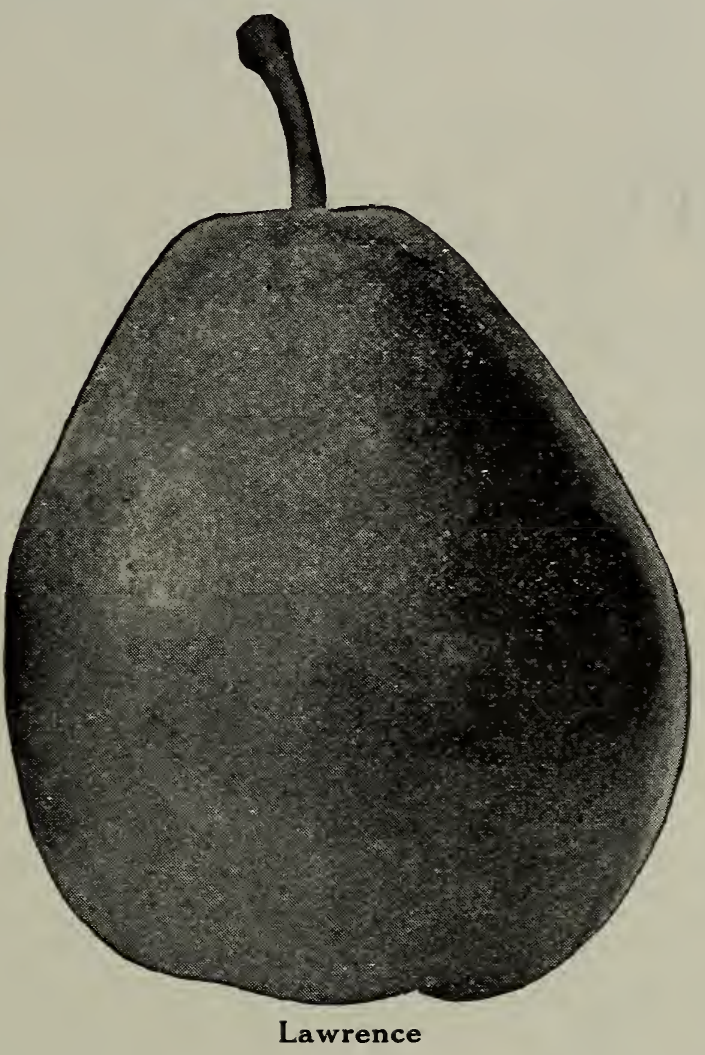
good. Tree hardy, vigorous and very productive. December.

\section{HARDY STANDARD PEARS}

The following varieties of standard pears we rate as hardy as the Tolman Sweet or Golden Russet apple, and we recommend their culture in those sections where our Hardy Apple list can be planted with safety. They can be grown where it is about impossible to succeed with Bartlett. We give their season of ripening at the North.

Beurre d'Anjou............ November

Clapp's Favorite.............. September

Flemish Beauty..September and October Koonce......................ugust

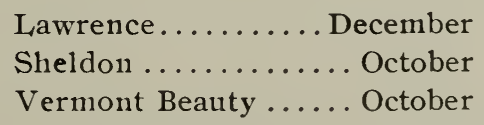

\section{DWARF PEARS}

As certain varieties of Pears are successful when grown as Dwarfs, we herewitlı give a special list of such as are nost suitable, and of which the Duchess d'Angouleme is decidedly the best of all.

Anjou

Bartlett

Clapp's Favorite

Duchess d'Angouleme
Kieffer

Lawrence

Seckel 


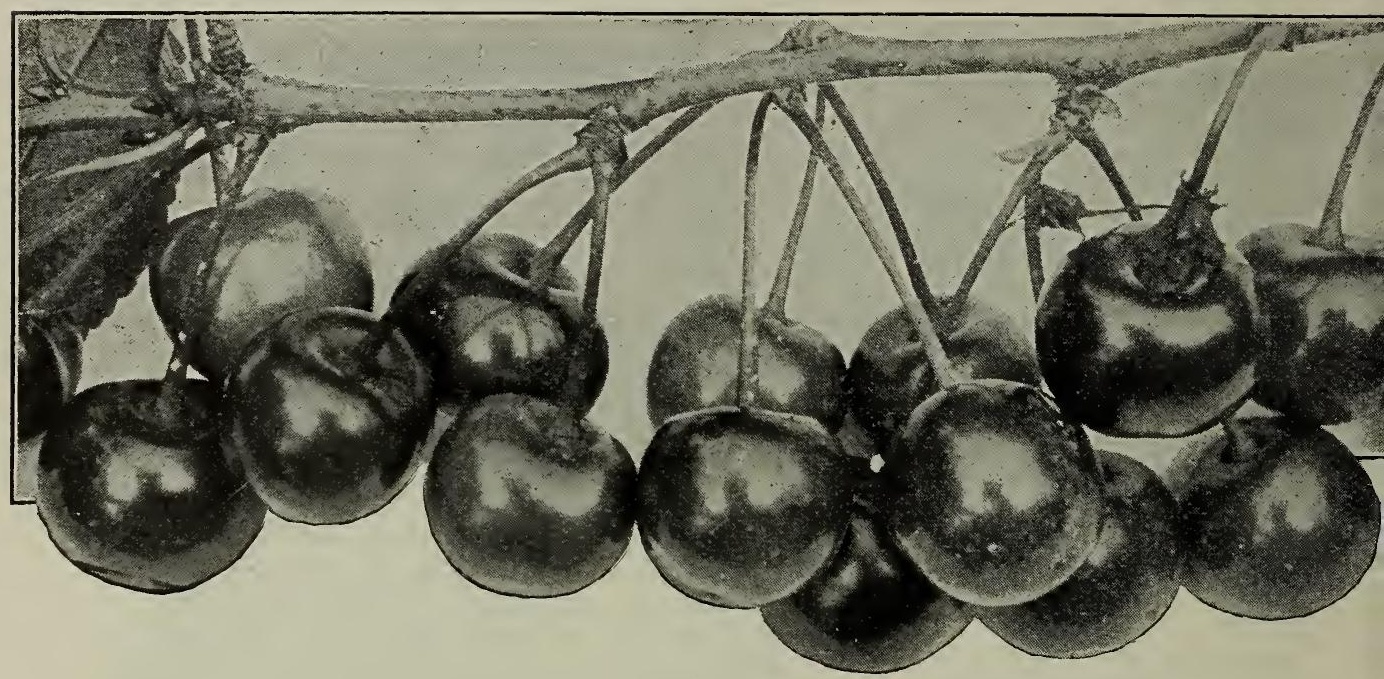

Montmorency

CHERRY

The Cherry thrives best on a dry, sandy, or gravelly soil, and there it attains its highest perfection, but it will do very well in almost any situation except a wet one.

We divide them into two classes - Hearts and Bigarreaus, and Dukes and More11os. The first are strong and vigorous growers, making large, open, spreading heads or tops, and are best suited for the purpose of shade, producing a large, heart-shaped, sweet fruit. The Dukes and Morellos do not attain so large a size, are more hardy, less liable to bursting of the bark, and generally produce acid fruit.

\section{HEARTS AND BIGARREAUS}

Bing. A native of Oregon. Fruit very large, bright and glossy; color very dark crimson. One of the largest cherries ever produced and of most excellent quality. Season July.

Black Tartarian. Fruit very large, heart shaped, with an uneven surface; skin briglit black; flesh purplish, tender, rich and good. Ripens early in June.

Compass. Originated at Springfield, Minn. It is a cross between the Sand Cherry and the Minor Plum. Fruit nearly an inch in diameter, a bright red; sweet, juicy, fine flavor. Tree absolutely hardy in that severe climate. A regular and heavy bearer.

Dikeman. Fruit of the largest size, heart shaped, nearly black; flesh solid, rich and sweet. Never rots. Tree a vigorous grower, liardy and productive. Ripens late, after most of the sweet cherries are gone.

Governor Wood. Fruit roundish, heart shaped, light yellow, nearly covered with red; flesh tender, rich and sprightly. Ripens last of June.

Hoy. Very large, equalling the finest California cherries in size; very light color; unequalled by any other cherry in its high quality and richness of flavor. Tree is a rapid grower, hardy; foliage large and healthy, and fruit hangs in immense clusters, almost hiding the branches.

Mercer. Very large; bright purplish black; half tender, juicy, very rich, excellent flavor; productive First to middle of July. 
Napoleon Bigarreau. Fruit of the largest size; pale yellow with a bright red cheek; when fully ripe of an excellent flavor. Ripens early in July.

Ostheime. Large, heart shaped; nearly black when ripe; juicy and rich. August.

Rockport Bigarreau. Fruit large, obtuse, heart shaped; skin pale amber, light red in the sun; flesh rather firm, sweet, rich and excellent. Last of June.

Schmidt's Bigarreau. Fruit grows in clusters and is of the largest size; skin deep black color; flesh dark, tender, juicy, with a fine rich flavor; stone small. Early July.

Windsor. Fruit large, liver colored, resembling the Elkhorn, nevertheless, quite distinct; flesh remarkably firm, sweet and of a fine quality. July.

Yellow Spanish. Large; pale yellow with bright red cheek in the sun; flesh firm, juicy and delicious; one of the best, most beautiful and popular of all lightcolored cherries. End of June.

\section{DUKES AND MORELLOS}

Baldwin. Tree an upright vigorous grower, forming a round head; leaves large and broad; bloom pure white changing to pink; fruit large, almost round, very dark, transparent wine color; flavor slightly acid, yet the sweetest and richest of the Morello type; stems rather large of medium length, and generally in pairs. Unexcelled in earliness, vigor, hardiness, quality and productiveness.

Dye House. A sure and regular bearer, ripens before Early Richmond.

Early Richmond. Fruit medium size round; dark red; flesh

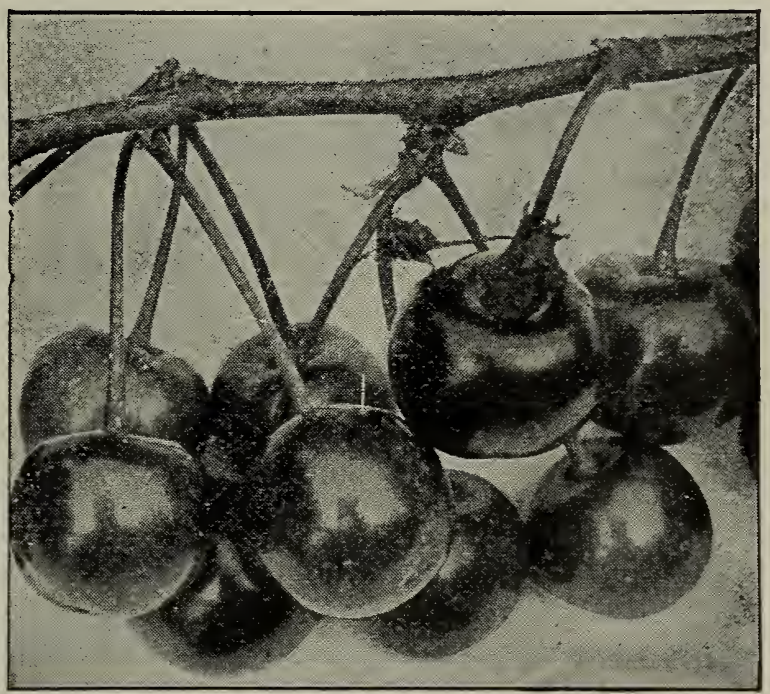

Bald win melting, juicy, rich, acid. Tree slender, not a rapid grower; great bearer. June.

English Morello. Large, dark red, nearly black; tender, juicy and of rich flavor. Season August.

May Duke. An old, well known, excellent variety. Large, dark red; juicy, subacid, rich. Middle of June.

Montmorency. A beautiful, large, red, acid cherry, larger than Early Richmond, and fully ten days later. Extraordinarily prolific and very hardy. It is a variety of great value. Habit of tree similar to Early Richmond.

Olivet. A new variety of French origin. Large, globular, very shining, deep red sort; flesh red, tender and rich; vigorous; very sweet, sub-acid flavor. Free. Middle to last of June.

Wragg. Supposed to hail from North Germany; very hardy. The tree is a good grower and immense bearer; fruit a dark, liver color, juicy and rich. Quite late and a valuable cherry. 


\section{THE PLUM}

The Plum does best on a strong clay soil, dry and well drained. Here it grows the most thriftily, and with cultivation, suffers least from "Curculis" or "Black K11ot." There is little trouble in keeping the trees free from insects and disease. After the blossoms have fallen spread a sheet on the ground under lie trees. Then jar the tree, so as to shake down the stung fruit and insects. These should be burned. This

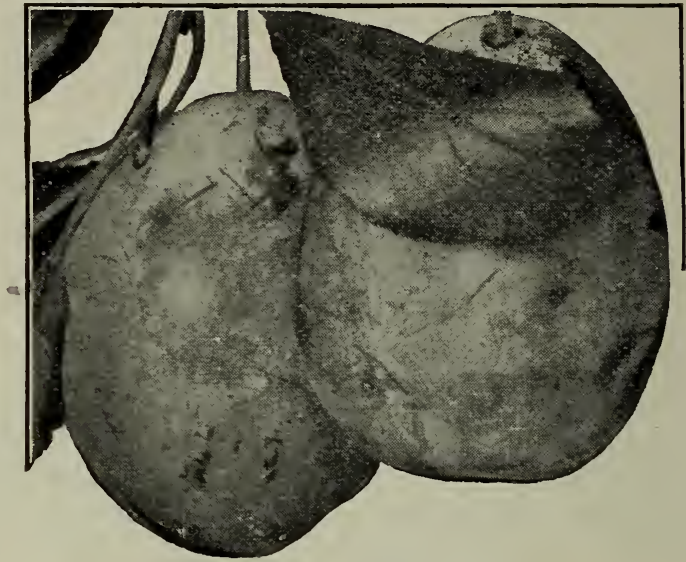

Lombard

should be done every day for a week or more, and it is important that it be done early in the morning.

Bradshaw. Large size; reddislı purple witl blue bloom; flesli juicy and ricl1. Tree vigorous and productive. August.

De Soto. Medium, briglit red, sweet and rich. Hardy and productive. Popular in West and Nortli.

Empire State. A nagnificent, very large, dark colored purple plum; shape rcund, quality the very best. The tree is a strong grower and very hardy. September.

Fellemberg. (Italian Prune.) Large, oval, purple; juicy and delicious; farts $\mathrm{f}_{1} \mathrm{~cm}$ the stone, fine for drying. September.

French Pruno. Fruit niedium, dark copper color, a riclı bloom and the best prune for market purposes we have fruited. Ripens late October.

Forest Garden. Fruit nearly oval, over one incli in diameter; flesh dark golden yellow, juicy and melting, with sweet spicy flavor. Season usually late and short.

German Prune. A large, long, oval variety, 11ucl esteenied for drying. Color daık purple, of a very agreeable flavor. September.

Geuii. Very large, dark purple. Hardy and productive. Very fopular in the plum growing region on the Hudson River. Ripens last of September.

Grand Duke. (New.) A valuable addition to late plums. As large as the Bradshaw, of same color, and ripening latter part of September. Entirely free from 1 ot. One of the best plums for market.

Imperial Gage. Fruit large oval, skin pale green, flesh juicy, sweet, rich and excellent. Tree very vigorous and productive. Middle of August.

Lombard. Fruit medium size, roundish, oval; skin violet red, flesh yellow, juicy and pleasant. Tree very vigorous, liardy and productive. Last of August.

Monarch. Very large oval, dark purple blue, freestone. Abundant bearer.

Moore's Arctic. Fruit grows in large clusters, large dark purple. Flavor very fine both for preserving and dessert. A long keeper. Vigorous. September.

Pride of Waterloo. (Description by Charles Downing.) "A $n \in W$ variety or iginated at Waterloo, N.Y., from the seed of the "Smith's Orleans." Tree a vigorous, upright grower, very productive; branches smooth reddislı brown; fruit large oval, narrowing a little toward the stalk, regular; skin light reddish purple with a thin blue bloom and many brown dots, stalk of medium length, flesh of deep yellow, juicy, sweet, sprightly.", 
Reine Claude. Fruit large roundish oval, skin greenish yellow, flesh, yellow, juicy, rich and excellent. Last of September.

Shipper's Pride. Fruit is of large size, dark purple color, fine, juicy and sweet, excellent for canning. Ripens from the first to the iniddle of September.

Shropshire Damson. A plum of fine quality, as free from the attacks of the Curculio as the Common Damson and of same color. The flesh is amber colored, juicy and sprightly. Very productive and a valuable market variety. Not liable to rot. Free. September.

Yellow Egg. (Yellow Magnum Bonum) Very large, egg shaped. Excellent for cooking, good and productive. Vigorous. Last of August.

\section{JAPANESE PLUMS}

To Japan we owe nany valuable fruits and flowers, but perhaps the most valuable in miny respects are the plums recently introduced from that country. First, the trees are hardy and perfectly healthy; second, they are remarkably strong and bəautiful growers and early bearers, orchard trees bearing the second season after transplanting; third, they yield immense crops of fruit, which is practically exempt from the attacks of the Curculio; fourth, by planting the differeat varieties, one can have plums for a period of nearly three months.

Abundance. The fruit is full medium size, color a rich bright cherry red with a distinct bloom and highly perfumed, flesh light yellow, very juicy and tender and of excellent quality. Last of July.

Burbank. In general character very similar to Abundance, but of deeper color and ripening later in the season. The fruit is large nearly globular, clear cherry red with a thin lilac bloom; flesh a deep yellow, very sweet, with a peculiar and very agreeable flavor. Tree is a vigorous spreading grower, with large and broad leaves, very prolific. Middle of August.

Hale. Large, orange color thickly overlaid with mottled red, very handsome; flesh yellow, with a very delicious, slightly acid flavor. An upright grower. Ripens with Satsuma.

October Purple. One of Luther Burbank's Hybrids and considered by him one of his best. Large, purple, yellow flesh. Very late.

Red June. Medium to nearly large, long pointed; deep vermilion red with a handsome bloom, very showy; flesh light lemon yellow or whitish, firm, moderately juicy, slightly sub-acid, of good quality, pit small. Tree upright, slightly spreading, vigorous, hardy and productive. Ripens before Abundance. Middle of July.

Wickson. Very large, glowing carmine with a heavy white bloom; flesh firm, sugary, delicious, pit small. It will keep two weeks or more after ripening, or can be picked when hard and white and will color and ripen almost as well as if left on the tree. Last of August. 


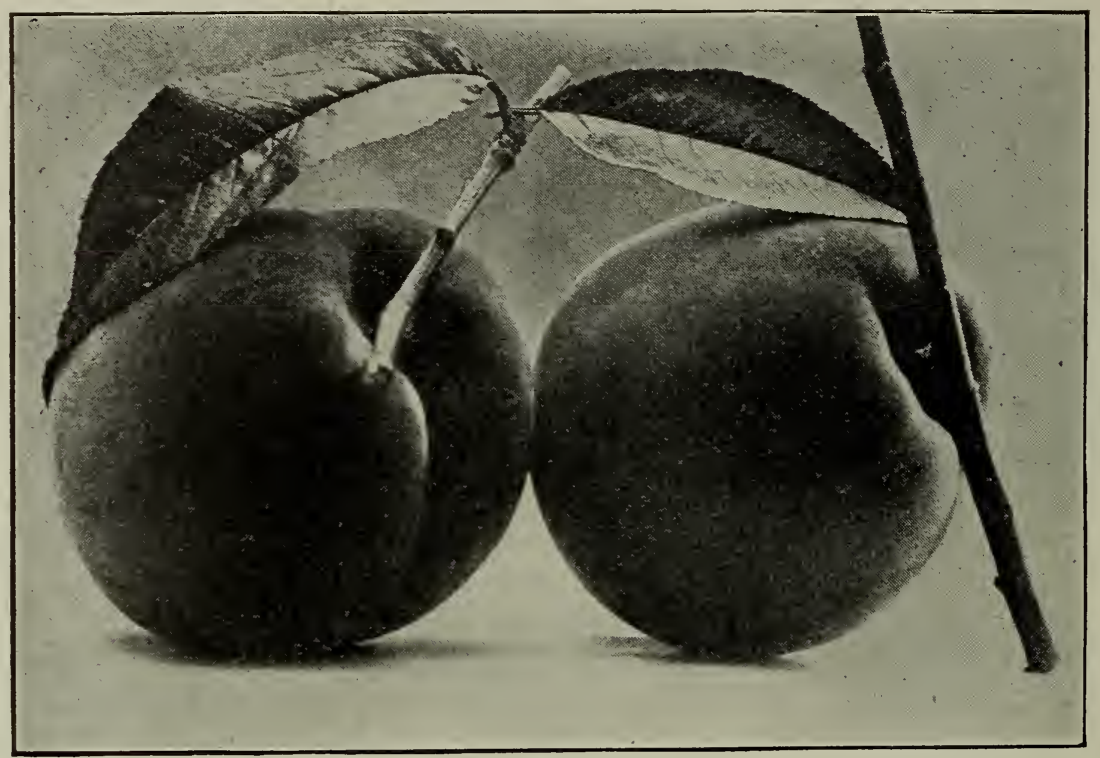

Yellow St. John

PEACH

For several years we have been giving special attention to the propagation of peach trees and are now, we believe, the largest growers in Western New York.

Our seedlings are grown from Western North Carolina natural pits, and guaranteed to be free from yellows and healthy in every respect. The selection of buds is given particular care, both as to purity and freedom from disease. We make it a rule to renew our buds at least every four years from orchard trees, thus insuring their genuineness. By thorough cultivation, our peach trees attain a good growth in the nursery without the aid of fertilizers, forming stocky, spreading trees, with well developed roots. By our system of low branching, the trees in the orchard are conveniently pruned, the fruit easily and cheaply picked, while there is no difficulty in cultivation.

The trees are dug, graded and packed with the greatest of care, and are marketed when one year old from bud.

Alexander. Medium, color deep maroon handsomely shaded, rich and good, flesh firm. Fine, hardy and productive. Early July.

Beer's Smock. Large to very large, yellow with red cheek, flesh yellow and of the very best quality for the season, freestone. A regular and enormous bearer, making it very desirable for market purposes. Last of September.

Belle. (Belle of Georgia.) Very large, skin white with red cheek, flesh white, firm and of excellent flavor. Tree a rapid grower, very prolific, fine shipper. Ripens with Crawford's Early.

Carmen. Large, broadly oval pointed; skin yellowish white dotted and flushed with red, flesh tender, creamy white, almost yellow, of a slightly vinous flavor. Free from rot. Ripens after Chase's Early. Middle of August. 
Champion. Delicious in flaror, sweet, rich and juicy; skin cream white with red cheek. Hardy, productive, size large, good shipper. Rifens early fart cf August.

Chair's Choice. Of largest size, deep yellow with red cheek, flesh yellow, very firm. October first.

Concord. Large, creany white and red, flesli pale and rich in flavor. Tree hardy and vigorous. September.

Crawford's Early. Large, yellow with red cheek, flesh yellow, rich, sreet and luscious. Ripens two weeks after Chase's Early. Middle of August.

Crawford's Late. Large size, fine quality, holds high rank as a profitable market fruit. September 25 th.

Crosby. The fruit is full medium size, round, oblate; color bright yellow, beautifully splashed and striped with crimson; flesh light yellow and red at the stone, firm, moderately juicy and of good quality. September 10 th.

Early Canada. Tree claimed to be unusually hardy. Fruit of good size, fine quality and beautiful appearance. Early July.

Elberta. Large, yellow with red cheek, juicy and of high quality, flesh yellow and melting. A very valuable sort, freestone. Ripens after Crawford's Early. Tree hardy and very productive. September first.

Fitzgerald. Originated in Canada. Fruit large, bright yellow suffused with red, flesh deep yellow, best quality, small pit, perfectly free. Tree comes into bearing young, is very productive and has proven to be one of the hardiest in wood and bud. Ripens just after Crawford's Early. Early September.

Foster. Yellow. Freestone. A large round peach of good quality, running uniform in size. Ripens with Crawford's Early.

Globe. Fruit exceedingly small, globular in form, quite uniform in size, of a rich golden yellow with a red blush; flesh very firm, coarse grained but juicy, yellow shaded with a red tinge toward the pit, freestone. Middle of September.

Greensboro. Ripens with Alexander, but is twice the size of that variety, and as beautifully colored - a bright red on a yellow ground. It ripens perfectly to the pit, from which it parts freely when matured. Flesh white, juicy and good. July.

Hale. Fruit fully one half larger than Elberta, color a deep golden yellow overlaid with bright carmine; smooth, solid thick skin; flesli deep yellow, fine grained, firm and as solid as a cling, yet parting freely from the pit. A peacl without the fuzz and distinctive in every respect.

Hill's Chilli. Medium size, dull yellow. Tree very hardy, a good bearer. Last of Sept.

Iron Mountain. Fruit very large, white, freestone, quality good. Very hardy in bud. White inside at pit. Sept.

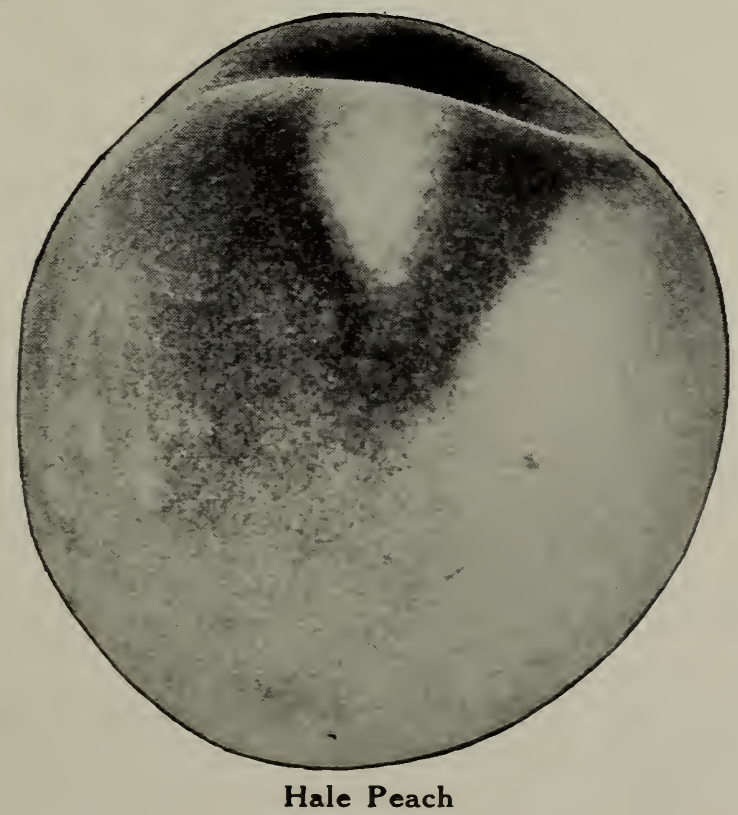


Kalamazoo. A leading market sort. Large, yellow, fine quality; extra productive and profitable. First of September.

Mayflower. A new variety of the greatest merit. In color is practically red all over even before it is ripe enougli to ship. It is the earliest peacl known and therefore extremely valuable as a market variety. A strong thrifty grower and an abundant bearer.

Mountain Rose. Large, red; flesh white, juicy, rich and excellent. One of the best early peaches. First of August.

Niagara. Large, beautiful and luscious. An excellent shipper. In Niagara County, N. Y., where it originated, it has borne lieavy crops of uniformly large fruit every season for the past six years, and it has slown complete freedom from blight and other forms of decay. Early September.

Old Mixon Fresstone. Fruit large, ova!; skin yellowish white with a red cheek; flesh white, but red at the stone; rich, sugary and excellent. Tree vigorous and very productive. Middle of September.

Ribroco. This is one of the most valuable of the new varieties. A large, handsome freestone witl golden skin, covered with a bright crimson blush. Flesh yellow, juicy. Valuable for market, a good slipper. Ripens after Crawford Early.

Salway. Irruit large, roundish; deep yellow with a rich marbled brownish red cheek; fleslı yellow, juicy, riclı and sugary. A new Finglish variety, a good keeper and promises lighly as a late showy market sort. Freestone. First of October.

Smock's Free. Ratler large, yellow witl a red clieek; flesli yellow, red at the stone. Productive. October first.

Steven's Rareripe. The fruit in appearance somewhat resembles an enlarged and remarkably high colored Old Mixon Free. White fleshed, juicy and high flavored. October first.

Stump the World. Large, creamy white with a bright red cheek; flesh white, juicy and high flavored. Middle of September.

Triumph. The tree is a strong grower, blossoms late with large flowers and is an early and abundant bearer. Fruit of large size with small pit; skin yellow nearly covered witl red, showing dark crimson on the sunny side; flesh bright yellow, ripening evenly to the pit. Ripens with Alexander. July.

Waterloo. A seedling originated in Waterloo, N. Y. Medium to large, skin whitish green marbled with purple, juicy and vinous. Ripens with Alexander, and is the best flavored of the earliest peaches.

Wheatland. Fruit large to very large, quality the very best, color a deep golden yellow. Tree a stout, sturdy grower and a great bearer. A most excellent shipper; freestone. Ripens between Crawford's Early and Crawford's Late. Middle of August.

Willet. This is undoubtedly one of the largest and finest peaches grown. Flesh yellow, juicy, rich and excellent; skin yellow, mostly covered with dark red; freestone. Last of September.

Wonderful. Large, smootl, almost globular; of rich golden yellow, largely overspread with vivid carmine, with marblings of crimson; flesh yellow, rich, high flavored and delicious, exceedingly firm, parts from the stone perfectly and dry, and is bright red around the pit. October first.

Yellow St. John. Nearly as large as Crawford, fully equal in color. Fruit round, brilliant, showy. One of the earliest peaches. August. 


\section{APRICOTS}

The apricot is one of the most beautiful and delicious of fruits. Like the plum, it is liable to be attacked by the Curculio, and requires the same treatment to prevent its ravages.

Alexander. Tree hardy, an immense bearer; fruit large, yellow flecked with red; very beautiful, sweet and delicious. July.

Alexis. Tree hardy, an immense bearer; fruit yellow with red cheek; large to rery large, slightly acid, rich and luscious. July.

Budd. Medium, rich, juicy, very fine.

Early Moorpark. Like the old Moorpark, but much earlier. A large, fine apricot; flesh orange, sweet, juicy and rich; parts from the stone. Very productive. July.

Harris. Tree hardy, comes into bearing young, and rery prcductive. Fruit large, rich golden yellow; ripens middle of July.

St. Ambroise. A good grower and very procuctive, of gcod quality, freestone. Excellent for drying or canning. Ripens about middle of July.

\section{QUINCES}

Bourgeat. A new golden variety of the highest qua!ity. Fruit of largest size, round, smooth, with a rich golden color; very tender when cooked; can easily be kept through January. Bush a remarkably strong grower, commences to bear very young and yields immense crops. Frequently commences bearing the seccnd season after transplanting.

Champion. Very large size; tree remarkably vigorous, bears when very young, quality the best. Keeps until January, and will not bruise when shipped.

Orange. (Apple) Fruit large, round, with a short neck; color bright yellow. Last of September.

Rea's Mammoth. A seedling of the Orange Quince, one-third larger, of the same form and color; fair, handsome, equally as good, and more productive. Last of September.

\section{MULBERRIES}

Downing. Higlily ornamental for street or lawn, yielding an abundant supply of very large, black, handsome berries, sweet, ricli ard excellent.

New American. Equal to Downing in all respects and a 1nucli hardier tree; vigorous grower; very productive; the best variety for fruit; ripe from the middle of June to the middle of September.

Weeping Russian. Forms a perfect umbrella shaped liearl, with long, slender branches drooping to the ground, parallel to the stem; very liardy. One of the prettiest small weeping trees. 


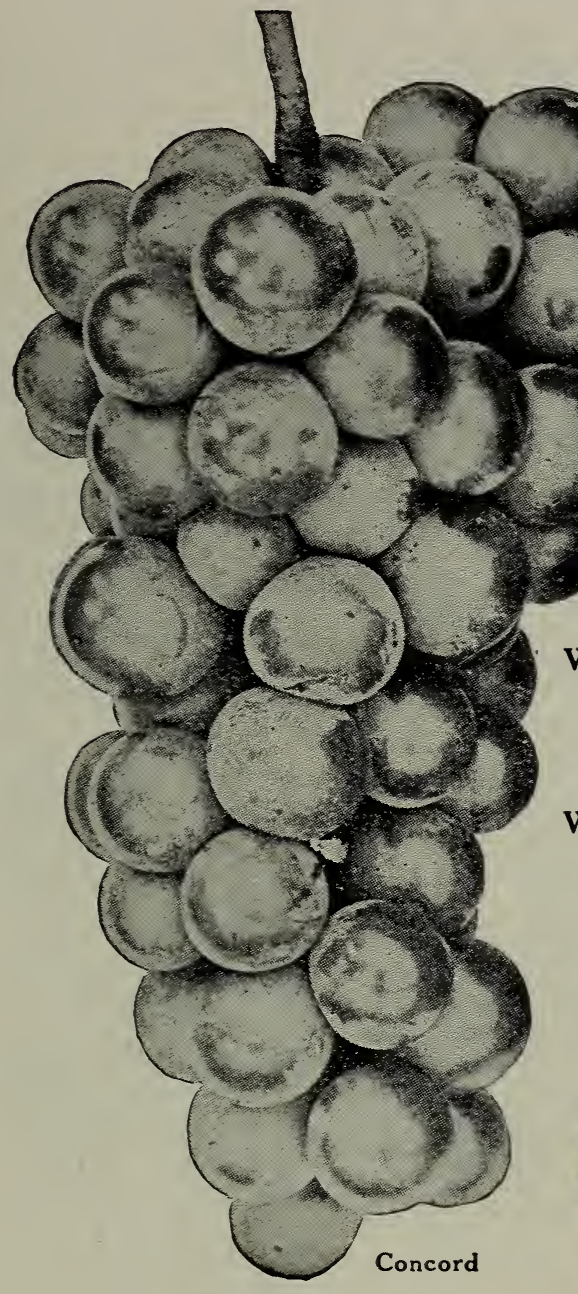

Empire State. Vine a vigorous grower, healthy and very productive; bunches large, shouldered; berry medium to large, roundish oval; color white with a very slight tinge of yellow covered with a white thick bloom; flesh tender, juicy sweet and sprightly. Ripens with Concord. September.

Green Mountain. White; bunches large and compact; berries large and of gcod quality. A fine early wlite grape. August.

Moore's Early. This rery valuable black grape is a seedling of the Concord. The rine is fully as hardy and healthy as its parent, while the fruit is large, more beautiful and of better quality. First of Sieptember.

Niagara. The vine is a strong grower and hardy; the leaves are a dark, glossy green, thick and leathery; bunches large and very compact; berries large; skin thin but tougli; quality fair. Early September.

Salem. Bunch 1 arge, shouldered, compact; berries large, round, Catawba color: skin thick and firm; flesh, sweet, tender, with a rich aromatic flavor. Vine moderately vigorous, hardy, healthy; ripens early. It is a splendid keeper. September.

Wilder. Bunch large, shouldered, compact; berries large; black skin, thin but firm; sweet, tender, good flavor; good keeper, moderate grower. September.

Worden. Bunches large, handsome, double shouldered; berries large, sweet, lively. Vine very thrifty, vigorous; perfectly hardy, healthy and a good bearer. September.

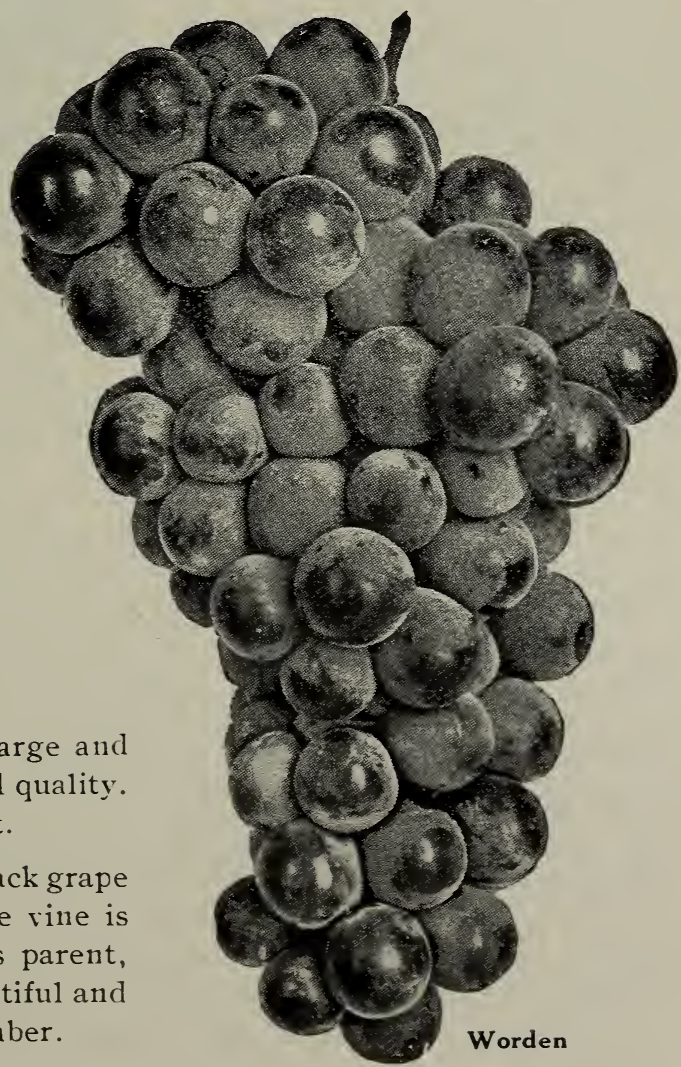




\section{CURRANTS}

Currants are the most profitable of small fruits. An acre yields from 200 to 250 busliels of fruit, bringing a price of from $\$ 4.00$ to $\$ 5.00$ per busliel. Plants should be set in rows four feet each way, allowing plenty of light and air. For protection against the currant worm dust a little white hellebore powder over the lushes when the leaves are damp. Do this as soon as worms appear.

Black Naples. Very large; black, rich, tender; excellent for jellies and wine; very productive.

Cherry. Very large; deep red; rather acid. Bunches short. Plants erect, stout, vigorous and productive.

Fay's Prolific. Originated in Chautauqua county, N. Y. A cross between Cherry and Victoria. Of large size, fine flavor, and claimed to be five tines as prolific as the Cherry. A great acquisition.

La Versaillaise. Very large; red; bunch long, of great beauty and excellent quality. One of finest and best, should be in every collection. Very prorluctive.

Lee's Prolific Black. New English variety; fruit large, of superior quality; bush a rigorous grower and enormously productive, rendering it very profitable.

North Star. Average length of the bunches is four inches, the berries from a single bunch, 30 in number, placed side by side, touching, covered a line 12

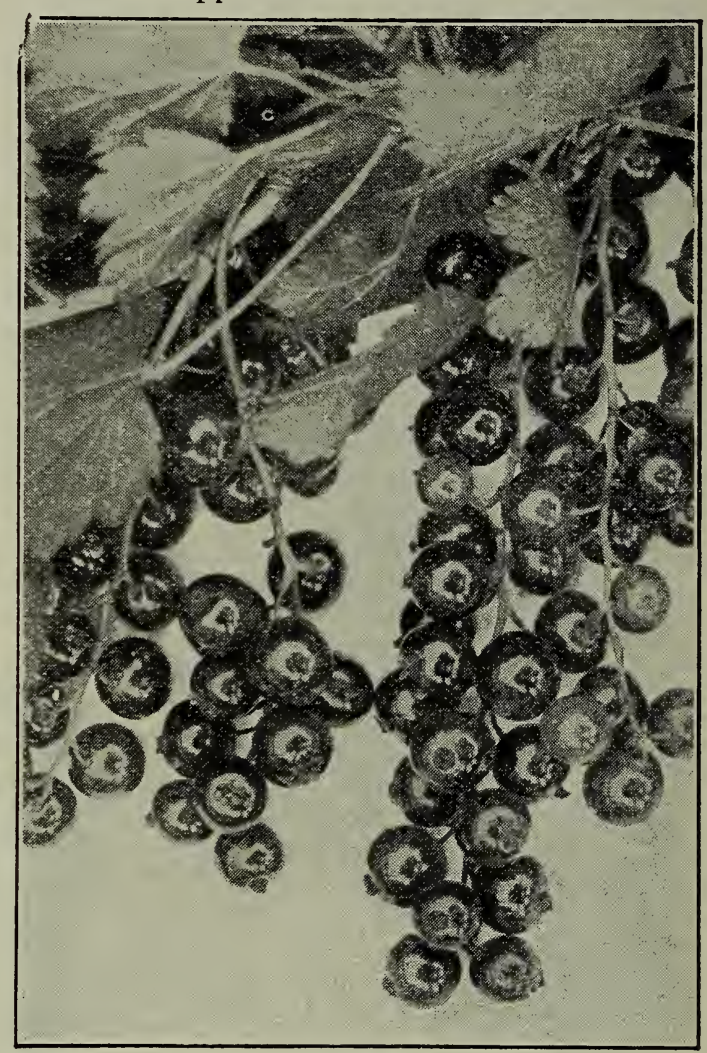

Cherry inches long. The fruit is very sweet and rich in quality, firm; a good market berry; desirable as a dessert fruit in its natural state, and unequalled for jelly.

Perfection. (New.) Larger than Fay's, clusters averaging longer; beautiful bright red; rich, mild, sub-acid; great bearer. Consider this an important introduction.

Pomona. Medium size; clear bright red; excellent quality; liangs long time after ripe; holds up well on market; is one of the best for shipping; easily and cheaply picked. Holds an unparalleled record for acreage yield.

Red Dutch. An old, well known sort, berry of medium size and good quality; bunch long, plant an upright grower and very prolific.

White Grape. Very large; yellowish white; rery mild acid; excellent quality and valuable for the table. The finest of the white sorts.

Wilder. A new red currant, originated in Geneva. Fruit the largest size, gcod color; rich and juicy; cluster large and well filled. Bush very upright and remurkably productive. Ripens later than Fay's, making it especially valuable. 


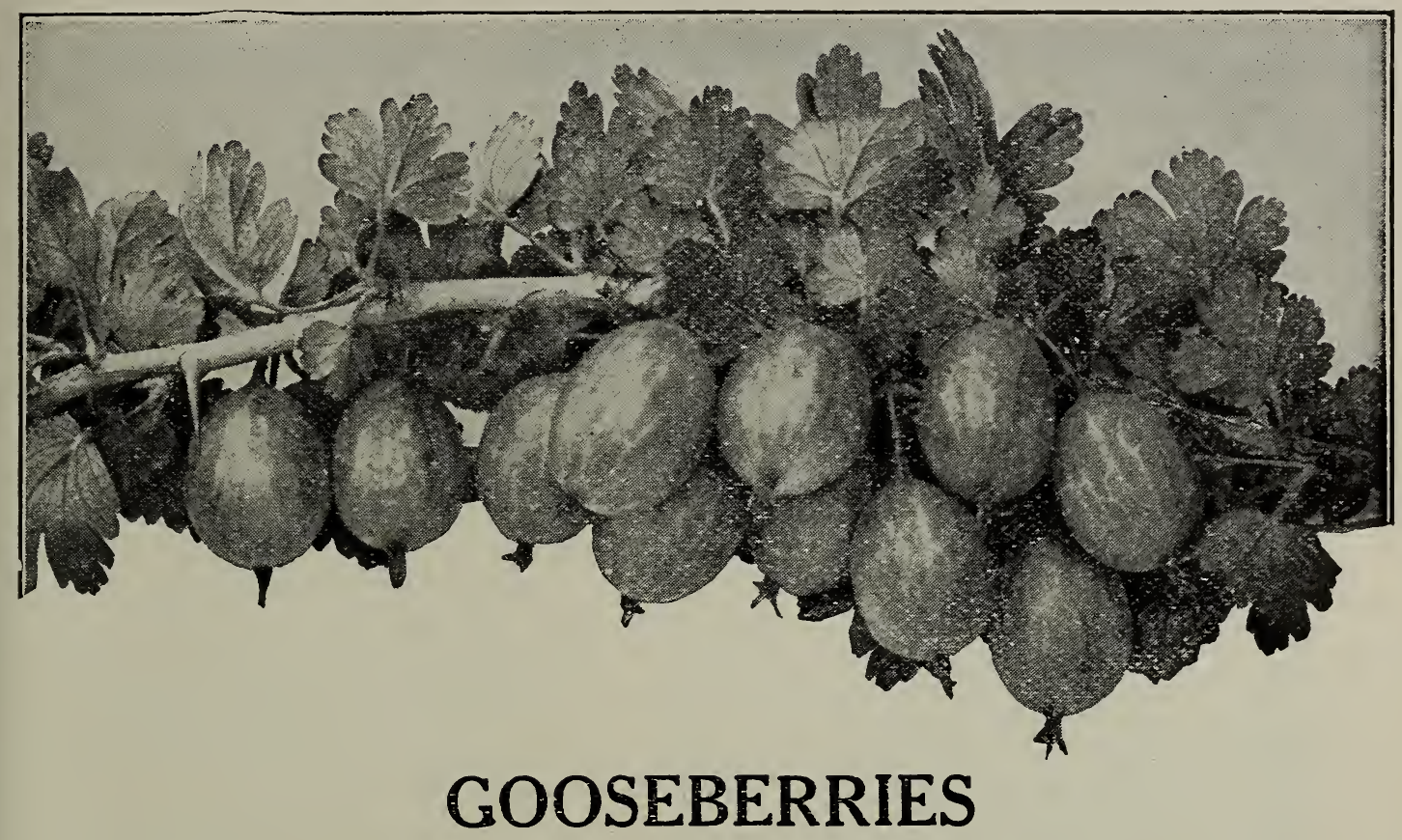

The interest in and demand for this fruit is constantly groning. Tle expense of cultivation is light and returns most satisfactory. Good plants sliould produce 200 bushels per acre third year after planting, and 300 to 400 buslels the fiftli year. Gooseberries bring $\$ 4.00$ to $\$ 6.00$ per bushel.

Columbus. An American seedling of English type. The fruit is of largest size, handsome, of a greenish-yellow color, and the quality is excellent. The plant is vigorous and productive and does not mildew. It merits a place in every garden.

Dominion. Our new gooseberry. It is a seedling of an English gooseberry and originated on the grounds of Mr. Lamb of London, Ont., some years ago. It is a strong grower, very hardy, a regular and very abundant bearer and unusually free from mildew. Foliage large and glossy; fruit large to very large, greenish yellow and beautiful; quality equal to the best. Its niany points of excellence combine to make it one of the greatest acquisitions among gooseberries.

Downing. Large size, oval; greenish white or pale yellow; plant very vigorous and hardy, with stiff, strong sloots and heavy foliage, which adheres.

Houghton's Seedling. Small to medium, roundish oval; pale red; sweet, tender, very good; plants spreading, slender; very productive. One of the best.

Industry. An English variety; quite as free from mildew as our American sorts; very fine in quality; large size. Handsome, slıowy red fruit, productive.

Red Jacket. (Josselyn.) Bush vigorous grower and productive; foliage healthy and rrot subject to mildew; berries of good size, heautiful red color, transparent and of nost excellent quality. New and a decided acquisition.

Smith's Improved. Fruit large, oval form; light green when ripe; sweet and excellent. Plant extremely productive, liardy and healthy.

Whitesmith. (English.) Large; yellowislı wlite, sliglitly downy; of very fine quality. 


\section{RASPBERRIES}

Raspberries are divided into two classes-Red varieties and Black Caps; the former are reproduced by suckers and root cuttings, the latter from the tips. The Red varifties succeed on almost all kinds of soils, but do not do as well on heavy clay as on lighter ground, while tle Black Caps do better on heavy than on sandy soil.

Black Diamond. Fruit large, good color, fine quality, firm, more pulpy and contains fewer seeds than most varieties. Plant, hardy, healthy and productive.

Columbian. Fruit very large, often an inch in diameter; shape'somewhat conical; color dark red bordering on purple. Bush a vigorous grower, canes growing from 10 to 16 feet in height, and often over an inch in diameter, strong and woody, becoming bright red in autumn; is very hardy and wonderfully prolific.

Cumberland. Bush is hardy, vigorous grower and exceptionally productive. Fruit of unifornı size and larger than any known black raspberry; many specimens are from 7-8ths to 15-16ths of an inch in diameter. In quality equal to Gregg, ripening a few days earlier than that variety. It is very firm, and a good shipper.

Cuthbert. Vigorous grower; very productive and perfectly hardy. Foliage luxuriant and tougl1, never burning. Berry of largest size and good quality. Ripens late.

Golden Queen. A seedling of Cuthbert, equalling that variety in vigor of bush. Fruit large; color a pure yellow; quality lest. Ripens with Cuthbert.

Gregg. One of the largest Black Caps grown; quality rich and sweet; a perfect shipper; bush hardy and wonderfully productive. Ripens rather late.

Herbert (Iron-clad variety). New; outclasses all in hardiness. Fruit is bright red, somewbat oblong in shape. Largest of all red raspberries; sweet, juicy. Very best for table use. Enormously prcductive; outbears the Cuthbert and is a week earlier. Holds its size well to the end of the season.

Loudon. The Loudon New Red Raspberry ripens with the earliest and hangs to the last. In productiveness it is beyond any red raspberry known, and is a famous shipping berry.

Marlboro. The best early red raspberry for the Nortl, ripening soon after the Loudon. Hardy and productive.

Ohio. Greatest producer a mong Black Caps; for canning or evaporating the most profitable of all. Berry not quite as 1 arge as Gregg, but finer quality, and the plants more hardy and will bear more successive crops.

Shaffer's Colossal. Berries large, of dull purplish, unattractive color; rather soft, but luscious; of ricl,, sprightly flavor. While its color

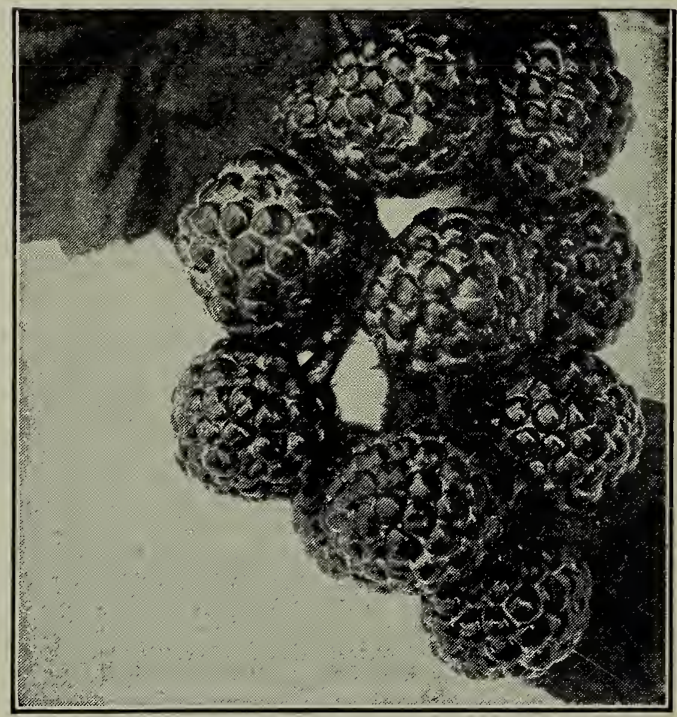

St. Regis, Everbearing and lack of firmness render it unfit for market purposes, it is unrivalled for family use, and is one of the best for canning. Late. 
St. Regis. One of the greatest raspberries ever introduced. Plants of the St. Regis put out in the Fall or early April gave ripe berries on the 20th of June. For four weeks thereafter the yield was heavy and the canes continued to produce ripe fruit without intermission until late October. The berries were large and beautiful, firm and full flavored, to the rery last. See cut on opposite page.

\section{BLACKBERRIES}

Blowers. "The Giant of all Blackberries." An upright mammoth grower, very hardy and enormously productive. A single plant produced orer 2,600 berries. It commences to ripen about the middle of July and bears about two montlis.

Early Harvest. The earliest ripening blackberry; medium size; synmetrical; deep glossy black. Requires close pruning and high culture.

Eldorado. One of the liardiest; fruit medium to large; sweet, juicy, good color.

Erie. The busli is lealthy and very productive, as well as liardy. Fruit large, round, jet black and good quality. Ripens early.

Himalaya. A vigorous grower, making a growth of 30 to 50 feet in one year, whicl can be trained on a fence or arbor, similar to grape vines. The enormous clusters of 1 a rge sized berries ripen all summer, making the Himalaya the most

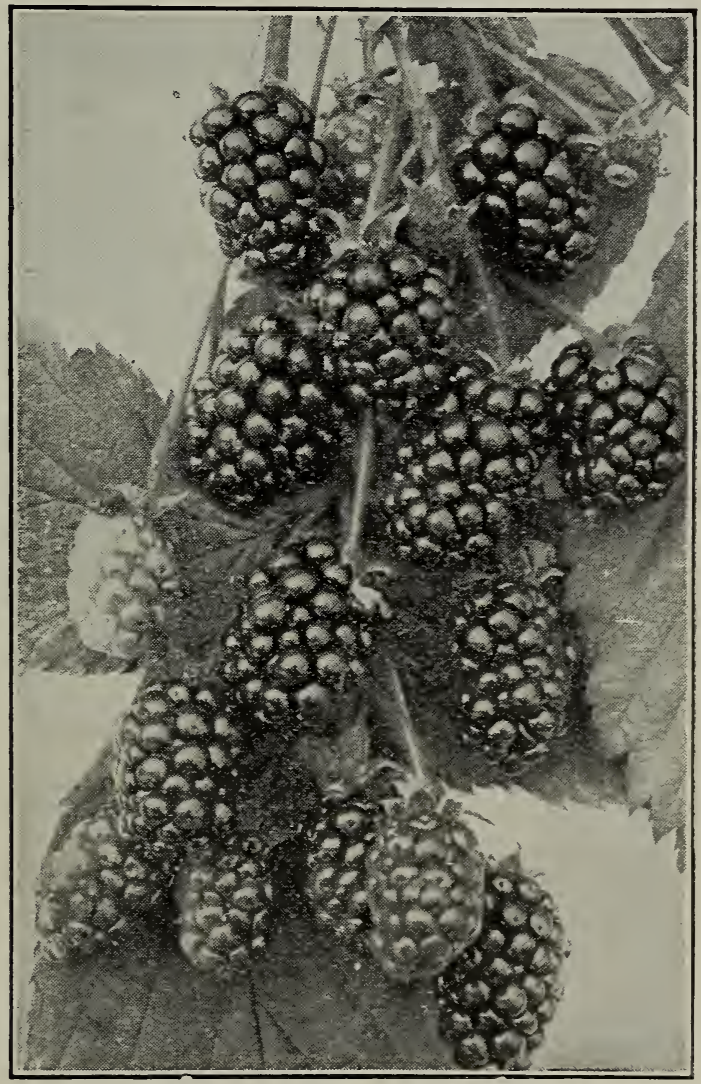

A Bunch of Blowers Blackberries productive of any variety known. No core, and the flavor is sweet, of unusual riclness; when ripe will literally melt in your mouth. For pies, jellies and dessert the Himalaya berry is a perfect success, being ahead of any similar fruit.

Iceberg. A wlite blackberry. Profuse bearer; delicious flavor; a decided novelty.

Lucretia Dewberry. Though not strictly a blackberry, we list this with blackberries. Bush is hardy, vigorous grower and productive; fruit of gocd size, carries well and ripening before blackberries, commands a ready sale. In many sections it is being extensively planted for market.

Rathbun. The plant is a strong, erect grower and produces but few suckers. The tips, late in the season, touch the ground and root, thus propagating thenselves in the manner of the Elack Cap raspberry. Witl midsummer pruning, it can be trained to tree form. In hardincss it ranks with Snyder and Wachusett. 
Snyder. Medium size; one of the most productive varieties; perfectly hardy; strong grower; delicious quality. Desirable for home use or the market.

Wachusett. Fruit medium to large, oblong, oval, moderately firm, sweet and gcod. The plant requires fair soil and good culture.

Wilson's Early. Very large size, oblong, oval, moderately firm; rich, sweet and good; ripens early and matures all its fruit rapidly. Bush tender.

\section{STRAWBERRIES}

We do not recommend the packing of strawberries with other plants and trees. Orders must be booked on regular strawberry order blanks which will be furnished upon request. Plants will be mailed or expressed direct to the customer and are not delivered at residence. We can furnish all leading varieties at the following rates:

\footnotetext{
50 Plants......\$ 1.50

100 Plants...... 2.25

1000 Plants...... 12.00

Express paid by us.
}

It is preferable to dig and ship straw-

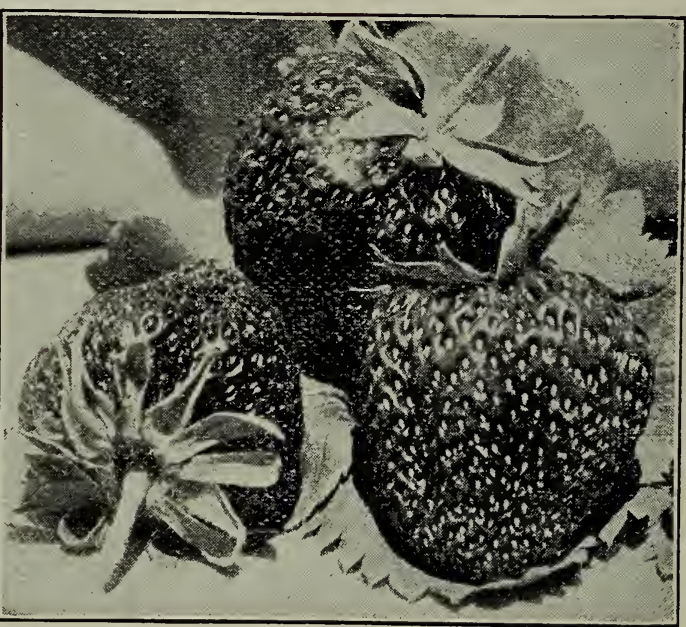
berry plants in the Spring.

\section{ASPARAGUS}

Barr's Mammsth. Another improved kind which has many elements of popular favor, especially good for market gardeners and those who grow for canning purposes.

Conover's Colossal. Highly recommended for its immense size and being remarkably tender and high flarored.

Palmetto. A very early variety. Even, large size; excellent quality.

\section{HORSE RADISH}

Will stand a great deal of hardship and persist in soil year after year. Plant in deep, rich, cool soil. The yield will vary according to the soil and treatment. As high as ten tons have been secured from an acre.

\section{RHUBARB}

Myatt's Linnaeus. This is without doubt the best variety in cultivation; stalk long and heavy, without being stringy or tough, with a mild sub-acid flavor.

Victoria. A remarkably productive variety. Stalk strong, thrifty and tender. 


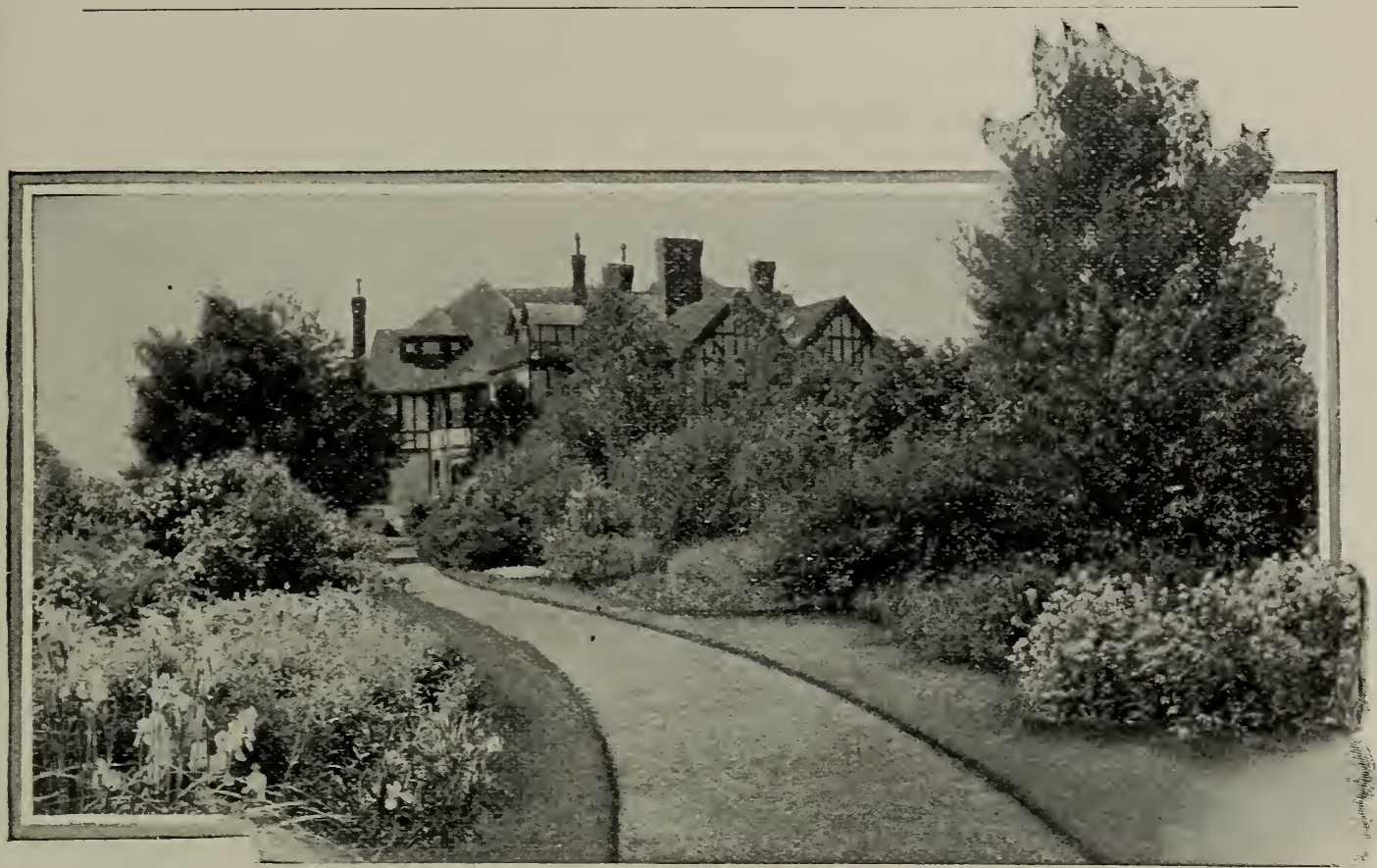

\section{ORNAMENTALS}

Our stock of ornanientals is the very best that can be produced. Everything which we send out in this department is strictly first class. We desire to call attention to the fact, however, that there are but few ornamentals which are liandsome when delivered, even when propagated in the most approved manner and selected with greatest care. But it is no sign, Lecause a sort is not of Leautiful fom when delivered, that it will not when planted grow to be of graceful shape; indeed it is characteristic of many lovely and charming kinds to be of irregular and scraggling growtl while young. It is well to remember, then, that no nurseryman can make some varieties grow in good shape in the nursery; they must be planted on the lawn and given time to develop.

Our trade in the ornamental department is steadily growing, and there is an increasing demand all over the country for this class of stock. People are realizing that the town lot, as well as the country villa, is of greater value when rendered beautiful and attractive by a judicious selection of ornamentals. The expense is a trifle compared with the increased value of a place after it is so adorned.

\section{UPRIGHT ORNAMENTAL TREES}

(Those varieties which do not retain their foliage during the winter)

ALDER [A/nus].

European. A remarkably rapid growing tree, attaining a height of from 30 to 60 feet. Foliage roundish, wedge-sliaped and wavy. This species is specially adapted to moist situations.

Imperial Cut-Leaf (Laciniata imperalis). A cliarming tree, of stately, graceful growtl, having beautiful, ceeply-cut foliage. Vigorous and very lardy. Unsurpassed for the lawn. Attains a height of about 20 feet. 


\section{ASH [Fraxinus]}

This is a large family, but there are only a few varieties of especial merit.

European (Excelsior) A lofty tree of rapid growth, with spreading head and gray bark, pinnate leaves and black bud.

Gold Bark (Aurea). Conspicuous at all times, but particularly in winter, on account of its yellow bark and twisted branches.

\section{BEECH [Fagus]}

American. One of the finest American trees.

Fern-Leaved (Heterophylla). Of elegant form, round and compact. Fern-like foliage, delicately cut. The tree lias a wavy, graceful aspect, seldom seen in other sorts. When fully grown, 25 to 35 feet high.

Purple-Leaved (Purpurea). A most elegant lawn tree of striking appearance: 40 to 50 feet. Early in the season the foliage is deep purple, later it clianges to crimson, and again in the fall to a dull purplish green.

River's Smooth-Leaved Purple. The variety differs from the ordinary purpleleaved beech, having much larger and darker foliage.

\section{BIRCH [Betula]}

Graceful, airy trees, suitable for the lawn. They are hardy and thrive in all soils.

European White (Alba). Silvery bark and slender branclies. When fully grown, 15 to 30 feet high.

Purple-Leaved (Feliis purpureis). A vigorous grower; 20 to 25 feet when fully grown. Foliage purple.

\section{CATALPA}

The Catal pas flower in July when few varieties are in bloom and are therefore desirable. The blossoms are large and quite fragrant. Large heart-shaped, yellowishgreen leaves. Very effective, tropical looking lawn trees.

Bungeii. A species from China, of dwarf habit, growing only from three to five feet high. Foliage large and glossy.

Speciosa. A variety whicl lias become very popular throughout the country on account of its hardy nature. The trunks are liard and smootl, hence particularly adapted to forest planting, as its wood has been found to be very valuable for fence posts, railroad ties, etc.

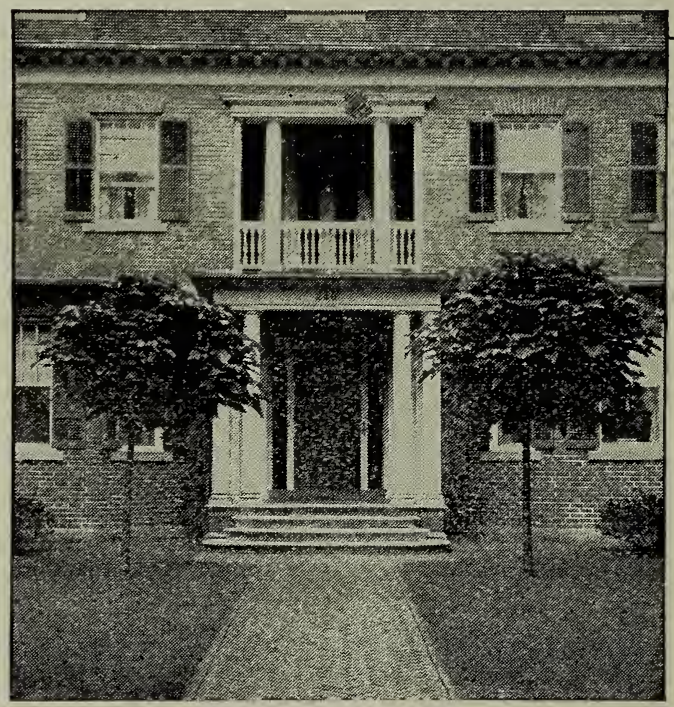

Catalpa Bungeii It is the most popular of the catalpas for street and park planting.

CHERRY [Cerasus]

Double-Flowering (Flore alba pleno). Blooms in May, and the flowers are so numerous as to completely hide the branches from view; blossoms white and very double. When fully grown, 15 to 20 feet high. 


\section{CHERRY-Continued}

Japan Weeping. A beautiful ornamental for a lawn. Blocms profusely in July; has a delicate green foliage.

\section{CHESTNUT [Castanea]}

American Sweet (Americana). The well-known native sort.

Japan. One of the finest of the imported varieties. Entirely hardy. Nuts large.

Paragon. Seedling of Spanish. A variety bearing the largest nuts of all, three or more in a burr. The tree is handsome and ornamental to the lawn and bears when quite young.

Spanish (Vesca). Valuable for both ornament and fruit. A handsome lawn tree, producing larger fruit than the American. Makes a large tree.

\section{CRAB}

Bechtel's Double Flowered American. One of the most beautiful of many fine varieties of flowering Crabs. Tree of medium size, covered in early spring with beautiful, double, fragrant flowers of a delicate pink color. From a distance, the flower has the appearance of small roses. A great acquisition, and certain to become very popular as known.

Parkmanii. A double-flowering variety from Japan; a compact grower, with ileep dark green foliage. Blooms very profusely, literally covering the tree.

\section{DOGWOOD}

American White (Florida). A native tree of fine form and beautiful foliage, growing from 20 to 25 feet high, producing white flowers three inches in diameter early in spring before the leaves appear. A very desirable tree.

Red Flowering. First disseminated by Thomas Meehan and considered a great acquisition.

\section{ELM [Ulmus]}

For street and park planting there is 110 finer tree than the noble American Elm of our own forests. There are also other varieties of great value for the law11.

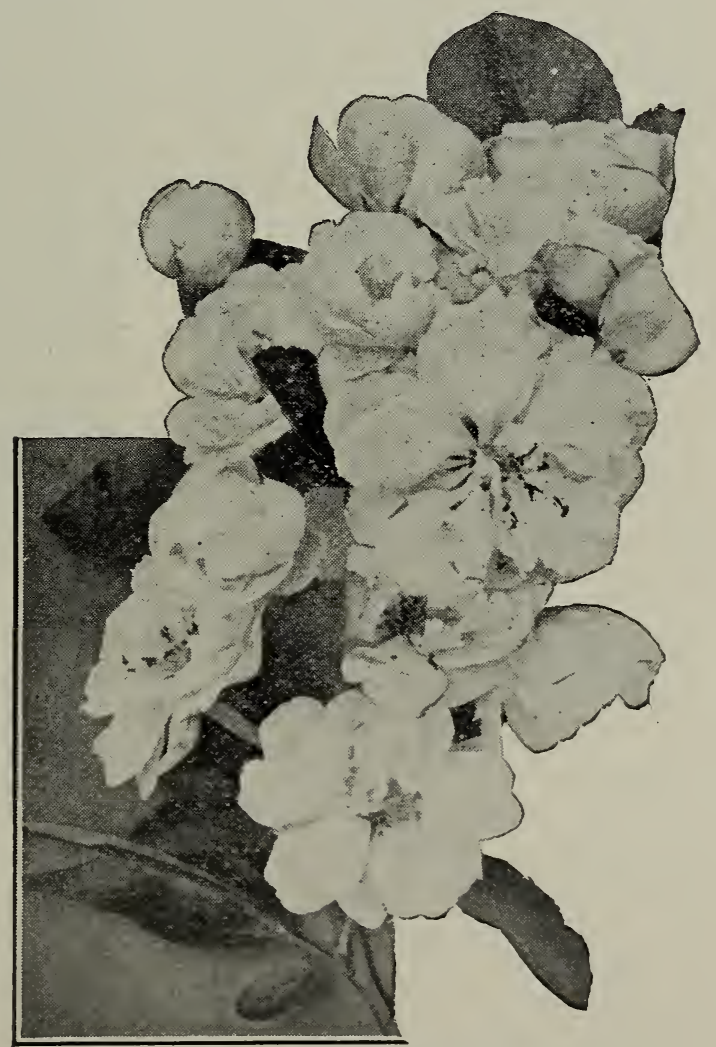

Blossom, Bechtel's Cráb

American White or Weeping. Tlie well-known native sort.

English (Campestris). Snall lear es and darker colored bark tlan tle American. The branclies project from the trunk nearly at right angles; 40 to 50 feet when it has attained full size.

Purple-Leaved. A liandsone lawn tree, with purple leaves and erect branches. A beautiful contrast to the green and golden-leaved Eilms. 


\section{ELM-Continued}

Huntingdon. Erect, vigorous and quick in growth, with clean, smooth bark. One of the finest Elnis for any purpose.

Scotch or Wych. A grand, spreading tree of rapid growtl and variable habit. Attains a height of 100 feet and forms a broad, round-topped liead. Best for lawns, but makes a splendid street tree.

HICKORY [Noyer, Fr.]

Shell Bark or Shag Bark. The most ornamental and valuable of the genus. The nuts are whiter and the shell thinner than those of other species.

\section{HORSE CHESTNUT [Aesculus]}

Horse Chestnuts are very desirable trees for the lawn, park or street.

Red-Flowering (Rubicuncla). Red flowers, very slowy. The leaves are darker than the WhiteFlowering. Blooms late in May, just after the White-Flowering. A slow rather crooked grower.

White-Flowering (Hippocastanum). Decidedly the finest variety of this family. Makes a beautiful tree of regular outline. Exceedingly hardy, and free from all diseases; 40 to 50 feet when fully grown.

\section{JUDAS-TREE or RED BUD [Cercis]}

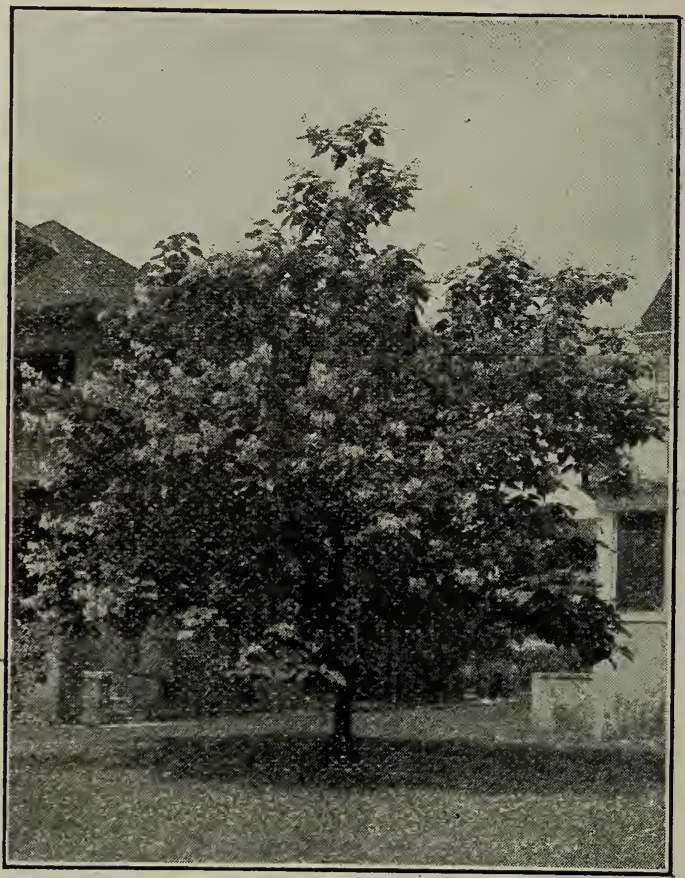

White-Flowering Horse Chestnut

The Judas deserves to be classed among the most beautiful ornamental trees.

American (Canadensis). Delicate pink flowers. Blossoms before the foliage ap. pears. Leaves perfectly heart shaped. A pretty tree for the lawn.

Japan (Japonica). Deep green, heart-shaped leaves. Rich, very pink flowers, quite large. Blooms in early spring. Makes but a small tree.

\section{LABURNUM [Cytisus]}

The peculiar chain-like blossoms of the Laburnum are highly prized.

Common or Golden Chain. Smooth, shining foliage, and long, drooping racemes of golden flowers; blooms in June; 10 to 15 feet.

\section{LARCH [Larix]}

European (Europæa). A rapid-growing, pyramidal tree. Sma11, drooping branches. Makes a large tree.

\section{LINDEN or LIME [Tilia]}

The Lindens are beautiful trees, and should be planted extensively.

American or Basswood (Americana). A rapid-growing, beautiful native tree, with very large leaves; fragrant flowers; 40 to 60 feet. 


\section{LINDEN-Continued}

European (Europæa). Forms a fine pyramidal tree; the flowers are fragrant and the foliage large; 30 to 50 feet.

White-Leaved European. From Hungary. A vigorous growing tree, of medium size and pyramidal form, with cordate acuminate leaves, downy beneath and smooth above. It is particularly noticeable a m ong trees by its white appearance. Its handsome form, growth and foliage render it worthy, in our opinion, to be classed aniong the finest of our ornainental trees.

\section{LIQUIDAMBER}

Sweet Gum. A fine native tree. Foliage resembles the maple in summer, turning to a deep crimson in the autumn.

\section{MAGNOLIA}

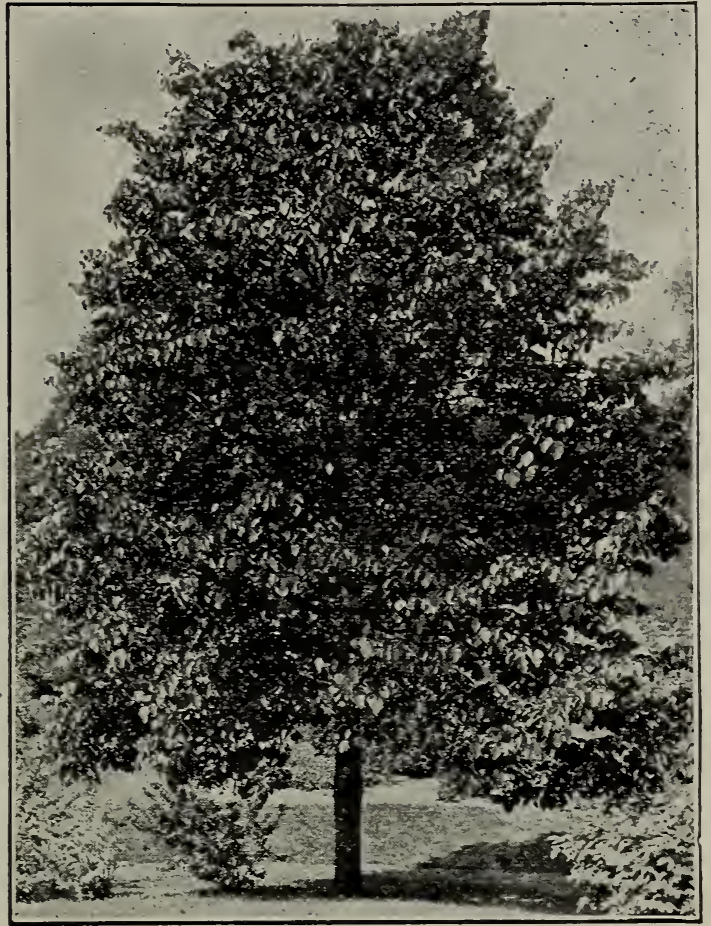

American Linden, or Basswood

The Magnolia is indeed "a thing of beauty," but it is exceedingly difficult to transplant with entire success.

Acuminata (Cucumber). A stately, pyramidical growing, native tree; 50 to 60 feet. Leaves six to nine inches long, bluish green. Yellow flowers, tinted witl bluish purple. The green fruit resembles the cucumber.

Conspicua, Chinese White Magnolia, Chandelier or Yulan Magnolia. A Chinese species of great beauty. The tree is of nedium size, shrub like in growth while young, but attains the size of a tree in tinle. The flowers are large, pure white, very numerous, and appear before the leaves.

Lenni (Lenne's Magnolia). Foliage large, fowers dark purple. A superb variety.

Soulangeana. In habit it closely resembles Conspicua; slirubby and branching while young, but becoming a fair sized tree. Flowers white and purple, cupshaped, three to five inches in diameter. Foliage large, glossy and massive. One of the hardiest and finest of the foreign Magnolias. Blooms later than Consficua.

Tripetela. A hardy native, medium sized tree, with enormous long leaves and large, late, white flowers in June; four to six inclies in diameter, fragrant.

\section{MAPLE [Acer.]}

The vigorous growth, fine form, hardiness, freedom from disease, and arlaptability to all soils, renders the Maple one of the best of trees for the purpose of sliade.

Ash-Leaved (Negundo fraxinifolium). A hardy native sort; asli-like foliage; spreading head; rapi? growth. Very hardy. 
MAPLE- Continued

Japan Blood Leaf. One of the most siriking and handsome varieties of the Japanese Maples. Form dwarf and weeping. The leaves are of a beautiful rose color when young, and cliange to a deep and constant purple as they become older. They are also deeply and delicately cut, giving them an elegant fern-like appcarance.

Norway (Plantanoides). La rge, compact liabit, and broad, deep green, shining foliage. A stout, vigorous grower; 40 to 50 feet when fully grown.

Purple-Leaved (Purpurea). Leaves deep green on the upper side and purplish red underneatl, making it very" effective: when planted with other sorts.

Scarlet, Red (Rubrum). Produces small, deep red blossoms before the leaves appear. In Autumn leaves change to brilliant scarlet.

Sugar, or Rock (Saccliarinum). The well known native variety; 50 to 60 feet. Valuable for the street or park.

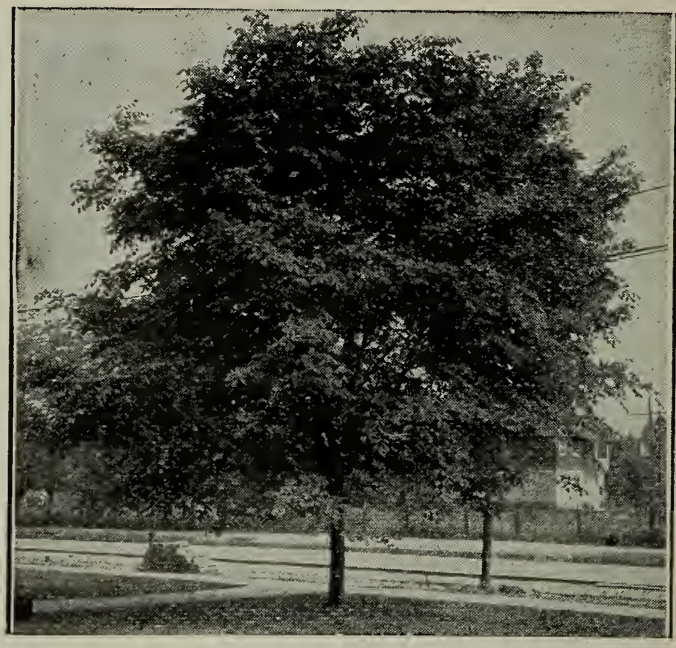

Norway Maple

Silver-Leaved or White (Dasycarpum). Foliage bright green above and silver underneath. An exceedingly rapid grower. Makes a large tree.

Sycamore European (pseudo-plantanus). A liandsome tree of upriglit growth; 25 to 30 feet. Large foliage and smooth, ash-gray colored bark.

Wier's Cut-Leaved (Wierii laciniatum). Grows very rapidly, and the sloots are so slender and drooping that it has a decidedly graceful appearance. The leaves are deeply and delicately cut.

\section{MOUNTAIN ASH [Sorbus]}

European (Aucuparia). A more desirable variety than the American, being of finer growth and form; 20 to 35 feet. It blooms during the early spring, after which the bright scarlet berries are formed in clusters.

Oak-Leaved (Quercifolia). Very showy, whether in blccm cr berry. The leaves are bright green and downy beneath. The blossom is white. Very hardy; 20 to 25 feet.

\section{MULBERRIES}

Downing. Highly ornamental for street or lawn; yielding an abundant supply of very large, black, handsome berries, sweet, rich and excellent.

New American. Equal to Downing in all respects and a much hardier tree; vigorous grower; very productive; the best variety for fruit; ripe from the middle of June to the middle of September.

White Mulberry. A native of China. Tree small, and of slender, rapid growth. Fruit pinkish white. 


\section{OAK [Quercus]}

The Oaks, when they attain size, are our most picturesque trees. The species and varieties are numerous, and the majority are adapted to ornament large grounds where they can have an abundance of room. Some kinds, however, are moderate growers, and suitable for small places, especially if kept in good shape by a judicious use of the knife. Our collection embraces a variety of forms and includes the finest.

American White Oak. One of the finest American trees, of large size and spreading branches; leaves lobed, pale green above and glaucous beneath.

English Oak. Royal Oak of England, a well known tree of spreading, slow growth.

Golden Oak. Beautiful golden yellow foliage that holds its color during entire season. Odd and desirable.

Pin Oak. Foliage deep green, finely divided; assumes a drooping form when it acquires age. One of the most valuable. A good grower. Fine for streets.

Scarlet Oak. A native tree of rapid growth, pyramidal outline, and especially remarkable in Autumn, when the foliage changes to a bright scarlet.

\section{PEACH [Persica]}

Double Rose-Flowering (Flore rosea pleno). Flowers double, pale rose colored, like small roses. A pretty tree; blooms in May.

Double White-Flowering (Flore alba pleno). Exceedingly ornamental. Flowers double and pure white. A very attractive tree; blooms in May.

\section{POPLAR [Populus]}

Poplars are desirable when rapid-growing varieties are wanted, and they are also very distinct and striking.

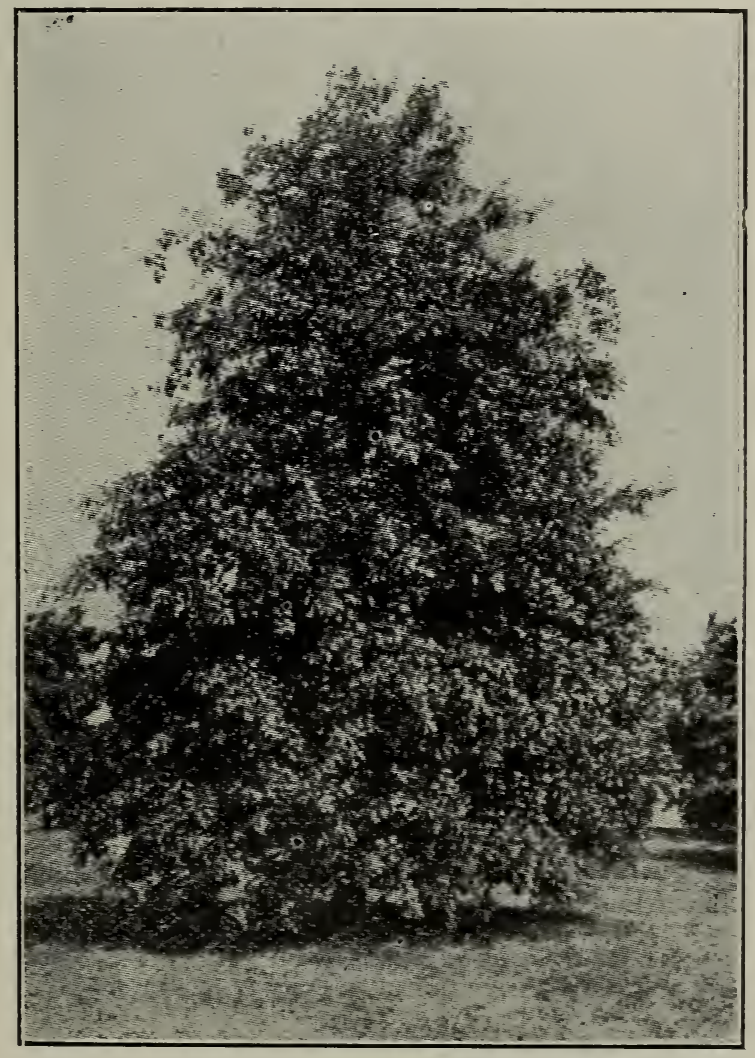

Pin Oak

Carolina (Modilifera). Pyramidal in form. Very rapid grower; 50 to 60 feet. Desirable for seashore, and for large cities where escaping gas kills most shade trees.

Lombardy (Fastigiata). Remarkable for its erect, rapid growth, and tall spiry form; 50 to 75 feet.

Silver-Leaved (Alba). Large leaves, green above and pure white underneatli. Wide-spreading growth. Has a bad habit of throwing up suckers.

\section{SALISBURIA}

Maiden-Hair or Ginko Tree (Adiantifolia). One of the most beautiful lawn trees. From Japan. Beautiful, ricl1, glossy, fern-like foliage. Rapid growth. Rare and elegant. A tall, up-ight grower. 
SYCAMORE [Platanus]

Oriental Plane. This tree is fast becoming popular for street planting. It is a rapid, upright, clean grower and long lived; beautiful dense foliage. It is not affected by the air of cities or by insects.

THORN, or English Hawthorn [Cratægus]. The Thorns are dense, low-growing trees, and varieties which we describe are exceedingly ornamental when in bloom.

Double Pink (Rosea flore pleno). Pretty tree at all times, but gorgeous in June, when it is covered with double pink blossoms.

Double White (Alba flore pleno). A lighly ornamental variety on account of both foliage and flowers. Small, double white flowers; blooms in June.

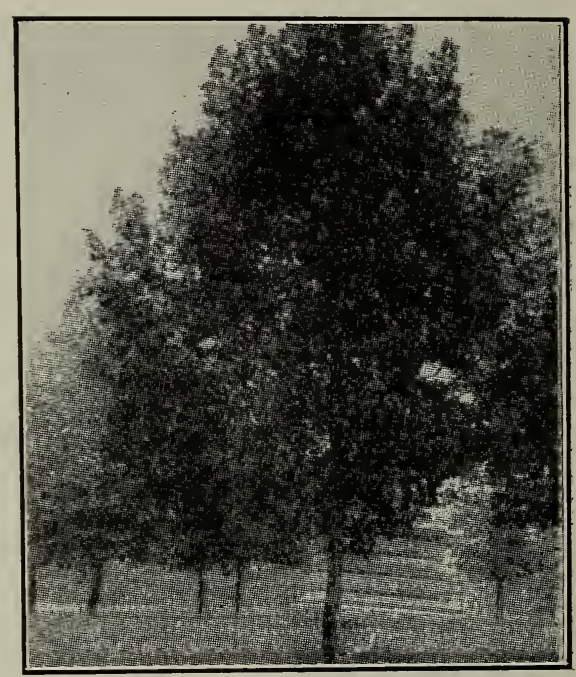

Sycamore

Paul's Double Scarlet (Coccinea fl. pl. Paulii). The flowers are large, very double, borne in clusters, a rich crimson color; blooms in June.

TULIP TREE [Liriodendron]

Tulipifera (White Wood, erroneously Yellow Poplar). A very large native tree. Pyramidal habit, with broad, fiddle-shaped leaves; tulip-like flowers.

WALNUT [Juglans]

The Walnuts are more suitable for large grounds and parks than for small enclosures. The nuts are valuable; they grow to a large size.

Butternut (Cinera). A familiar native sort, bearing a rough, oblong nut.

Black (Nigra). A native species, of large size and majestic form. Beautiful foliage; deeply furrowed bark. The nut is round and very palatable.

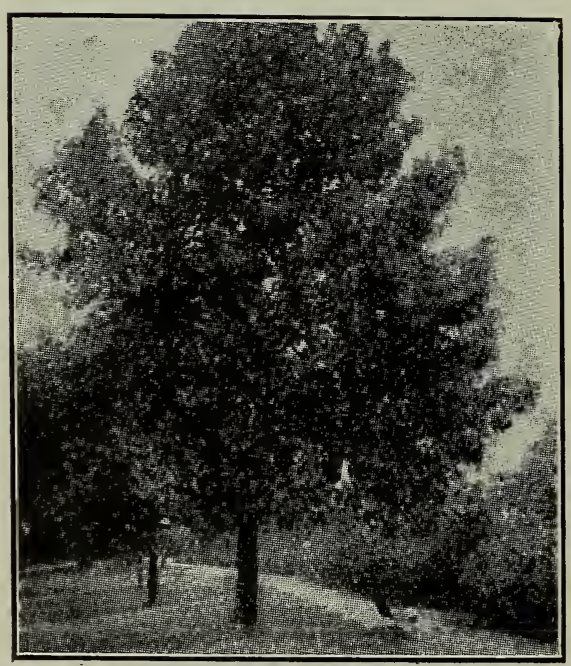

Tulip Tree
English, or Madeira Nut (Regia). A handsome tree, larger than the Butternut. Bears a very fine-flavored, round nut.

WILLOW [Salix]

Golden. A handsome variety of the wellknown Willow tree, with golden yellow bark, especially on the smaller branclies. Most beautiful in early spring before the leaves appear.

Laurel-Leaved. More like a large shrub of compact liabit. The foliage is very large, much like laurel.

Rcsemary-Leaved (Rosmarinifolia). Budded about five feet from the ground, this makes one of the most unique and ornamental of trees. The branches are feathery, the leaves silvery, and the form round and compact. 


\section{WEEPING ORNAMENTAL TREES}

The superior grace and excellence of the weeping varieties render then especial. $1 \mathrm{y}$ adapted to the yard or lawn. In our list will be found all of the kinds which we deem particularly attractive. Customers will, however, be saved from disappointment if they will realize that it is impossible to deliver them from the nursery with the form and shape which they will attain with age.

ASH [Fraxinus]

European Weeping (Excelsior Pendula). The common wellknown sort; one of the finest lawn and arbor trees, covering a great space and growing rapidly.

\section{BIRCH [Betula]}

Graceful, airy trees, suitable for the lawn. They are hardy and thrive in all seasons.

Cut-Leaved Weeping. Beyond question one of the most popular of all weeping or pendulous trees. Its tall, slender, yet vigorous growth, graceful, drooping branches, silverwhite bark, and delicately-cut foliage, present a combination of attractive characteristics rarely met witl in a single tree.

European White (Alba). Silvery bark, slender branches. When fully grown, 15 to 20 feet high.

Purple-Leaved (Feli is purpureis). A vigorous grower. Foliage purple. When fully grown, 20 to 25 feet high.

\section{ELM}

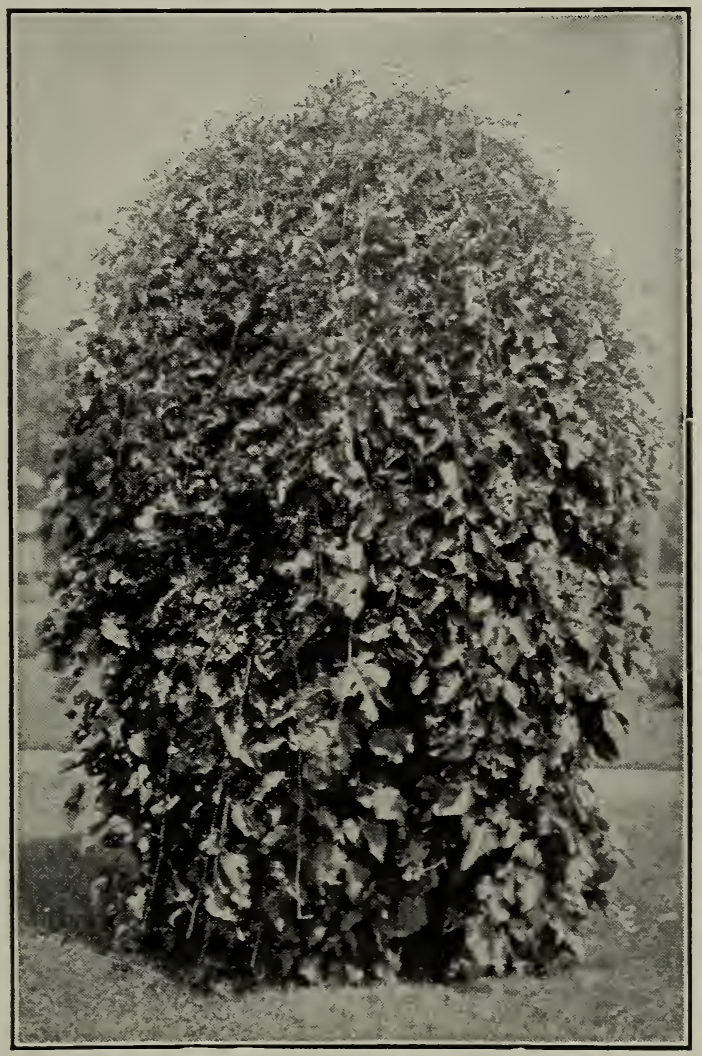

Teas' Weeping Mulberry (See next page)

Camperdown Weeping. Grafted six to eight feet higli, this forms one of the most picturesque drooping trees. It is of rank growtl, the shoots often making a zigzag growth outward and downward of several feet in a single season. The leaves are large, dark green and glossy, and cover the tree with a luxuriant mass of verdure.

\section{LINDEN, or LIME TREE ('Tilia)}

White-Leaved Weeping (Alba Pendula). A fine tree with large leaves and drooping branches.

\section{MOUNTAIN ASH [Sorbus]}

Weeping (Pendula) One of the best known and most popular weeping trees. It is of easy culture, great liardiness and thrives in all soils. Its straggling branclies, twisting and turning in every direction, with no training whatever, makes a most picturesque and novel sight. Covered during the Autumn wiil bright red berries. It is budded on stens about five feet liglı. 


\section{MULBERRY}

Teas' Weeping Russian. A weeping variety of the now well-known Russian Mulberry; perfectly hardy; withstands extreme heat and cold, and grows naturally in a very graceful form. (See cut on previous page.)

Weeping Russian. Forms a perfect unbrella-shaped head, with long, slender branches drooping to the ground, parallel to the stem. Very laardy. One of the prettiest swall weeping trees.

\section{WILLOW (Salix)}

Babylonica. The best known of all the weeping trees, and from which the class received its name on account of the way in which our forefathers planted it in cemeteries. Grows 30 to 40 feet ligh, and its long, slender branchlets, covered with slin, thin leaves, sweep to the ground.

Kilmarnock (Caprea pendula). Best known and most universally planted of the finer ornamental weeping trees. It occupies very little space and will thrive near larger trees, and is therefore invaluable for small enclosures. It is also well adapted for cemetery lots.

New American (Americana pendula). Grafted about five feet high. An interesting variety, witl delicate leaves and slender branches.

Wisconsin. A form of the common, and in all respects similar, except that it is hardy farther north.

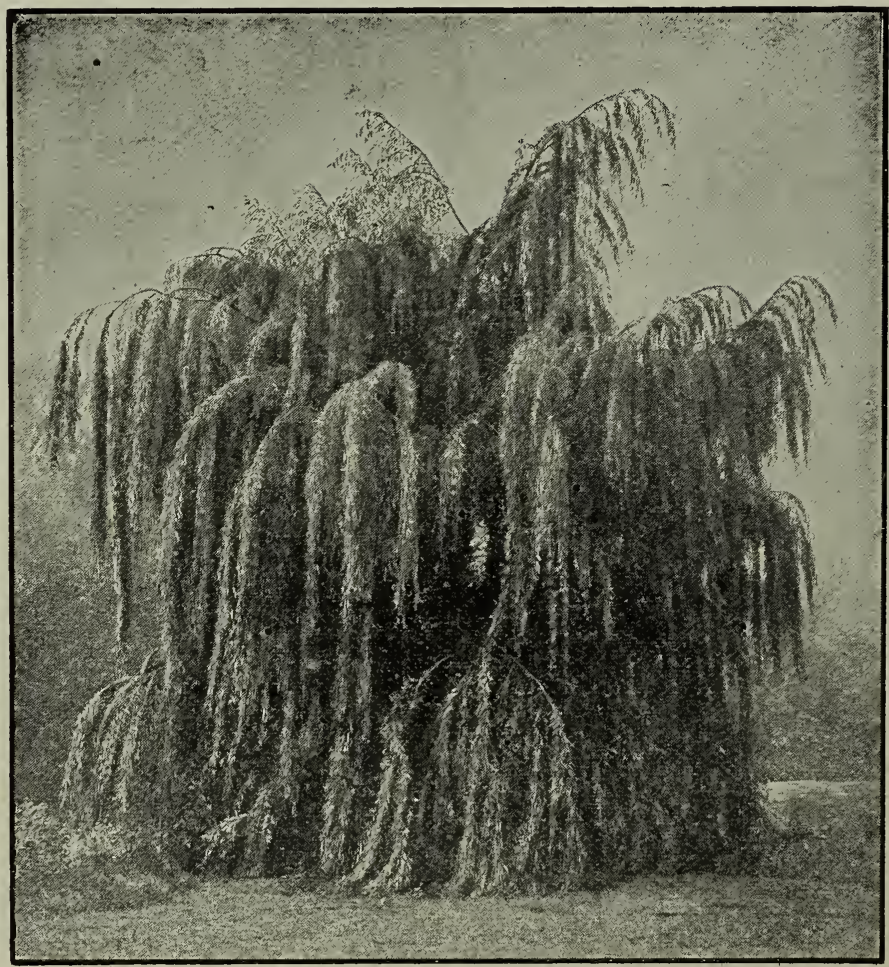

Babylonica-Weeping Willow 


\section{EVERGREENS}

Evergreens are exceedingly difficult to transplant, and they should never be set in the Fall. Even when planted in the Spring, and under the most favorable circumstances, a large percentage are liable to fail. In the liands of amateurs, failure is almost certain in all cases. For this reason we do $110 t$ like to sell Evergreens, yet we can supply the varieties described below when desired. We cannot furnish sorts not nan1ed in this catalogue.

\section{ARBOR VITAE [Thuja]}

American (Occidentalis). A native variety, valuable for hedges. Stands shearing well.

Hovey's Golden (Hovey). A seedling from the American. Yellowish-green foliage. Quite dwarf.

Pyramidalis. The most beautiful of all the Arbor Vitae, having dark green, compact foliage and remarkably erect form. Perfectly hardy.

Red Cedar. A popular sort which can be used ornamentally in a number of ways, thriving well and making a fine appearance in soils or situations where other trees will not grow. Compact. Grows 50 to 60 feet high.

Siberian (Sibericus). The liardiest variety. Good for hedges and screens, and the best for single specimens on the lawn.

Tom Thumb. A very pretty dwarf variety of the American. Valuable for small enclosures or low hedges; compact growth.

\section{CYPRESS [Cypressus]}

Lawson's (Lawsonia). Makes a large tree, with drooping branches; dark green foliage.

\section{FIR [Picea]}

Balsam, or American Silver. A very regular, symmetrical tree, assun1ing a conical form when young. Leaves dark green above, silver beneath.

Nordman's. Majestic tree of symn1etrical for111; n11assive dark green foliage; very effective.

\section{JUNIPER [Juniperus]}

Irish (Hibernica). A small tree or shrub of couical sliape, very erect and dense, desirable for centeteries.

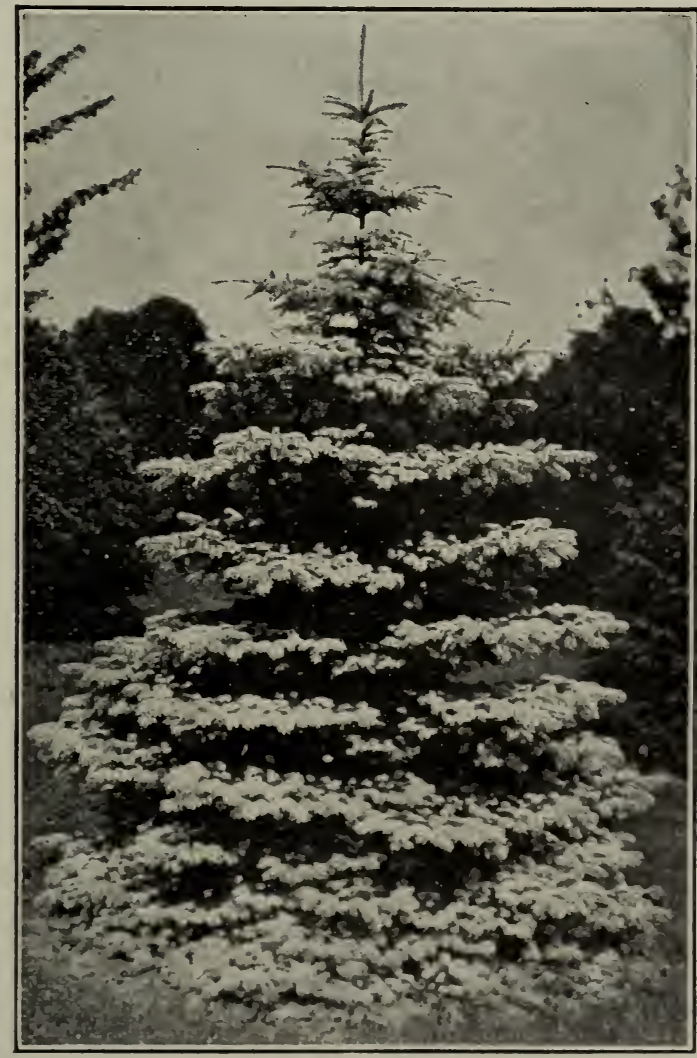

Koster's Blue Spruce (see next page) 


\section{PINE [Pinus]}

Austrian, or Black (Austriaca). A robust growing sort. Leaves long, stiff, dark green. Makes a large spreading tree.

Dwarf Mugho. A unique Alpine species, broader than its leight and sometimes almost prostrate, forming a dark, domeshaped bush, five to eight feet high. Used for planting on rocky banks, terrace slopes, small $1 \mathrm{awns}$, rockeries and near the sea.

Scotch (Sylvestris). A fine, robust, rapid-growing tree, witlı stout, erect shoots, and silvery, green foliage.

White. The well-known White Pine, which has furnished so much of the timber of this country. Ta11, stately and most beautiful of all our native Pines, reaching a height of 120 feet. It is also among the

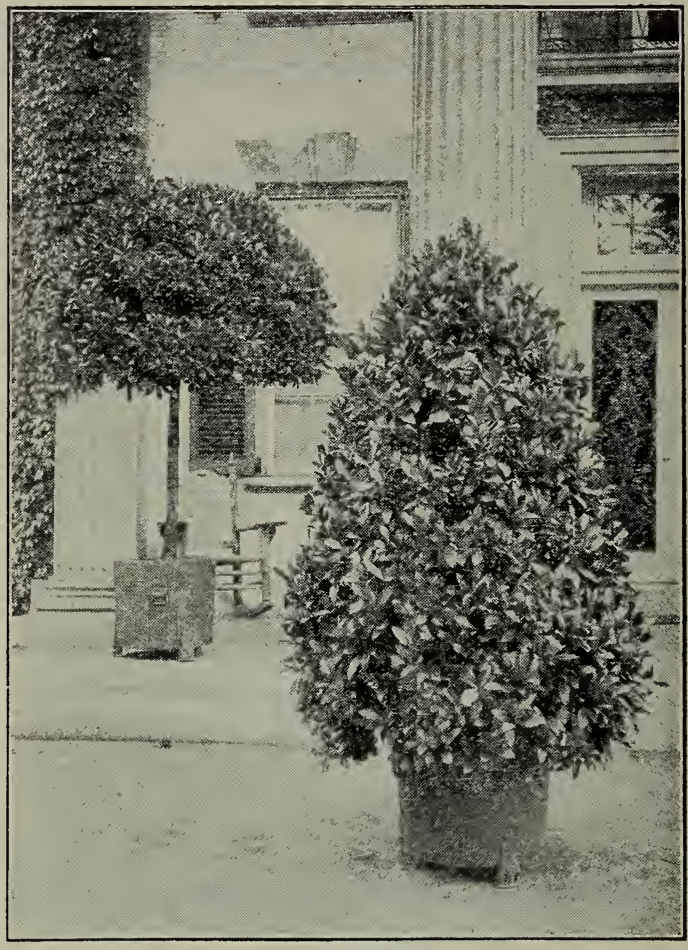

Tree Box quickest-growing, longest-lived an 1 most generally useful. The needles are long, silvery blue and plumy in effect. The tree grows naturally into symmetrical specimens and makes a most imposing feature on the lawn when growing singly.

\section{SPRUCE [Abies]}

Colorado Blue. One of the most distinctive and striking of the Spruce family. Foliage of a rich_blue color. A free grower and perfectly hardy.

Kosteriana (Koster's Blue Spruce). Similar to the preceding, except that the foliage is a much brigliter blue. Very rare. (See picture on preceding page.)

Hemlock (Canadensis). Delicate, dark-colored foliage, and drooping branches. Good for the lawn, also makes a good hedge.

Norway (Excelsa). A well-known species, of great hardiness, of rapid growth; pyramidal form; dark green foliage; branches sweeping, feathery and very graceful.

\section{TREE BOX}

Well-known ornament for lawn and porch, if placed in tubs. Foliage bright, glossy gree11. We can furnish fine stock in pyramid, round or bush form. State which style desired when ordering. 


\section{HEDGE PLANTS}

Hedges, aside from their value as protection against animals, as windbreaks and screens, are rapidly supplanting the old-fashioned picket and iron fences, and most beautiful effects are now possible. Ornamental hedges may be either deciduous or evergreen. Probably the most widely planted of the deciduous hedges is California Privet. Faultless in character and trims to any sliape.

BERBERRY [Berberis]

Common. Fin e low-growing slirub, with briglit golden-yellow flowers in clusters, followed by sliowy orange-scarlet $\mathrm{fruit}$, which liangs on well into winter.

Purple (Purpurea). Foliage and fruit of a violet purple color; very striking. Attains a size of from three to five feet.

Thunbergii. A beautiful Japanese variety; small green foliage changing to a deep red in the Autumn. Very desirable for grouping.

BOX [Buxus]

Dwarf Box. The well-known sort used for edging.

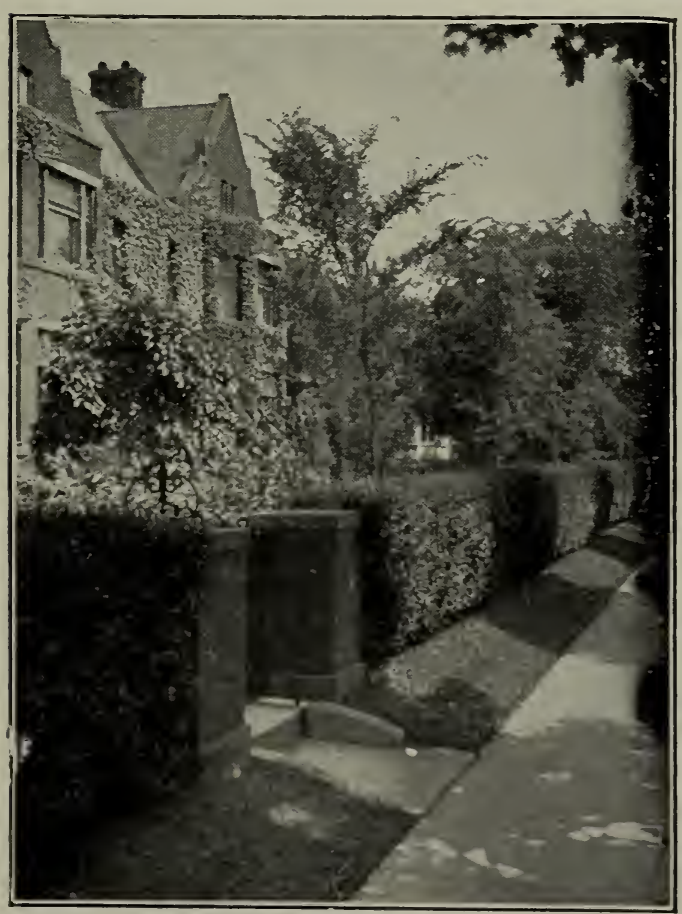

Hedge of California Privet

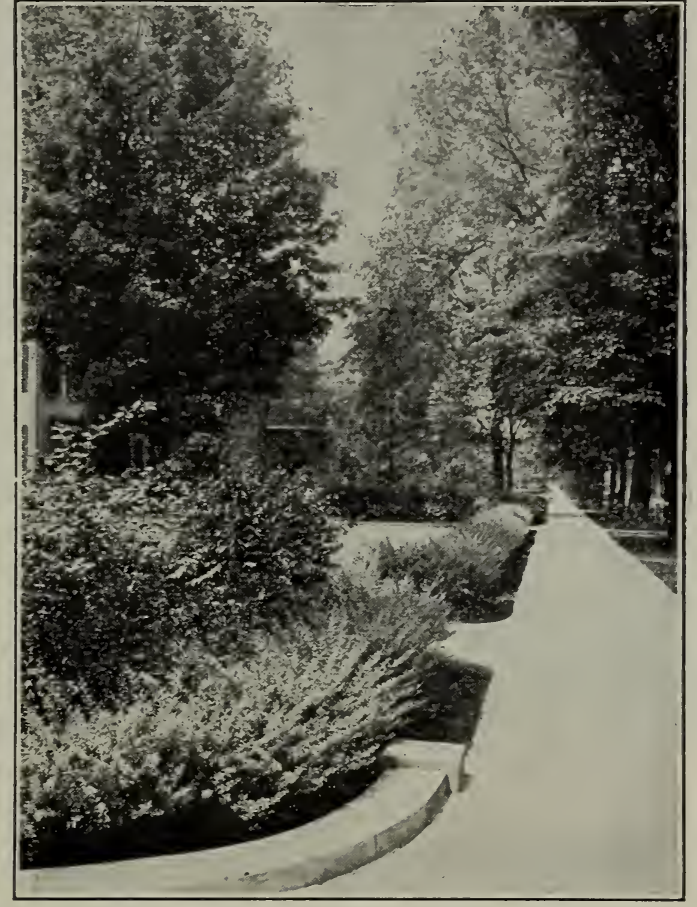

Hedge of Berberry Thunbergii HONEY LOCUST

Very hardy, and the cheapest and best for defensive liedges.

Black or Yellow. A native tree of large size, rapid growth, and valuable for timber as well as quite ormamental.

\section{OSAGE ORANGE}

Higlily esteemed in the West and South.

\section{PRIVET, California}

Iakes one of the handsomest rapid-growing liedges; thornless, with thick, glossy leaves remaining until late in the lall. Can be trinnmed to any desired lieight.

\section{QUINCE}

Japan. Grows very compactly; will submit to any anlount of pruning, while the brilliant and slowy scarlet flower makes it exceedingly attractive. 


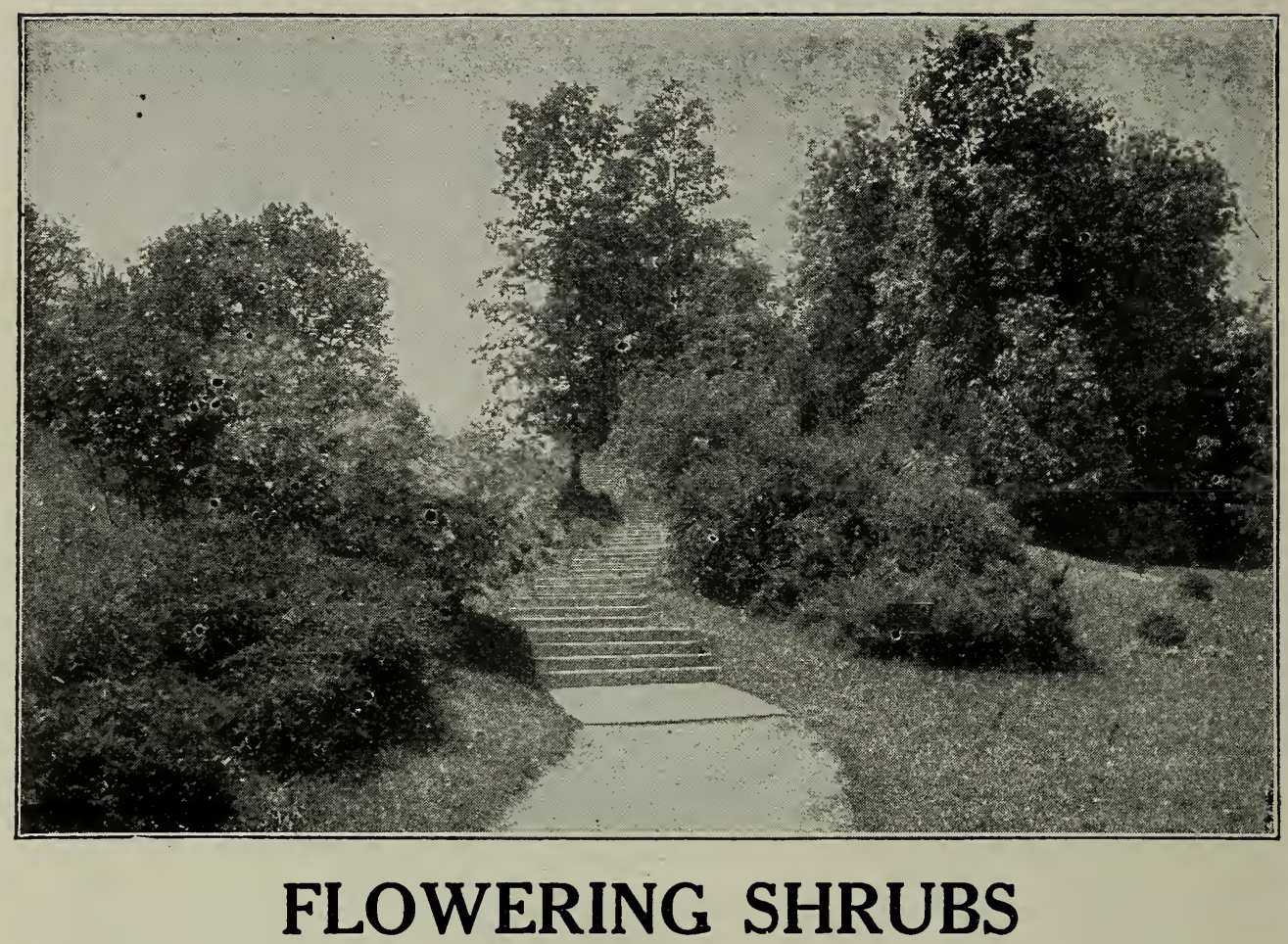

Flowering shrubs are most valuable among the ornamentals, whether planted in masses or as single specimens. Are indispensable in the parks, city gardens or the country home. A judicious selection will give abundance of bloom the entire season. ALMOND [Amygdalus]

The varieties which we name are hardy, charming shrubs, entirely covered with finely-formed flowers. They attain a size of from three to four feet.

Double Rose-Flowering (Japonica fl. pl.). Beautiful small shrub, producing in May, before leaves appear, small, double, rose-like flowers, closely set on the branches.

Double White-Flowering (Japonica $\mathrm{fl}$. alba pleno). A pretty sort, of small size, producing beautiful white flowers in May.

ALTHEA, or ROSE OF SHARON [Hibiscus]

The Altheas have a well-deserved popularity. They are free growers, and not particular as to the soil. They blossom in August and September, when but few other sorts are in bloom. They attain a height of from six to ten feet.

Double Purple (Purpurea fl. pleno).

Double Red (Rubra fl. pleno).

Double Variegated, Pink and White (Variegatus fl. pleno). The above are distinguished only by the color of the blossoms, the habit and foliage being the same in each variety. All have pretty, variegated flowers.

Variegated Leaved (fl. pleno fol, variegata). Distinctly variegated leaves, white and green.

\section{AZALEA}

Mollis. A splendid hardy species from Japan, and one of the most valuable flowering shrubs. Flowers large and showy yellow and different shades of red, in fine trusses. 
BARBERRY [Berberis]

Common Barberry (European Barberry). Handsome deciduous shrub, with yellow flowers in terminal drooping racemes in May or June, followed with orange-scarlet fruit.

Purple Leaved (Purpurea). Foliage and fruit of a violet purple color, very striking. Attains a size of from three to five feet.

Thunbergii. From Japan. A pretty species, of dwarf habit, small foliage, changing to a beautiful red in Autumn.

\section{CALYCANTHUS, or SWEET SCENTED SHRUB [Florida]}

Blooms in June, and at intervals through the Summer. Flowers of rare cliccolate color; ricl foliage. The wood and blossoms have an agreeable odor.

CLETHRA [Sweet Pepper Busli]

Alnifolia. Foliage light green, with numerous spikes of white flowers, borne in midsummer; of dwarf habit.

\section{CORCORUS [Kerria]}

Japonica. A slender shrub, with beautiful yellow blossoms; continuing from May until October.

\section{CORNUS [Dogwood]}

The varieties which we describe are distinct and valuable.

Elegantissima Variegata. One of the finest variegated shrubs; of rapid growth. The leaves are broadly margined with white.

Sanguinea (Red-branched Dogwood). A native species. Very conspicuous and ornamental in Winter, when the bark is blood red.

Variegated Cornus, or Variegated Cornelian Cherry (Mascula variegata). The flowers are bright yellow, borne in clusters in early Spring, before the leaves appear. Foliage is beautifully varigated with white. Makes a small slirub.

\section{CURRANT [Ribes]}

The flowering currants are wellknown slirubs; their hardiness, healthiness and early season of blooming are desi-able qualities. Attain size of from four to six $\mathrm{ft}$.

Crimson Flowering (Sanguineum). Small, deep red flowers; blooms in early spring very abundantly.

Yellow Flowering ( $A$ u $\mathrm{r}$ e u $\mathrm{m}$ ). Bright foliage, sulall yellow flower appearing in early spring.

\section{DEUTZIA}

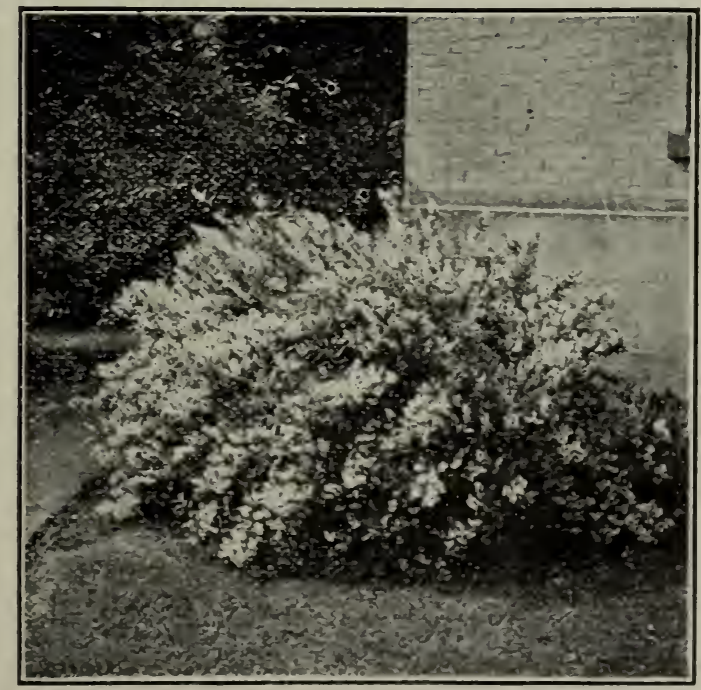

The Deutzias are of Japanese ori-

\section{Deutzia Lemoineii}

gin, extremely hardy, luxuriant foliage; very attractive flowers; very fine habit.

Candidissima (Double White Flowering). The flowers are showy white and of exquisite beauty. Bloons in June. 


\section{DEUTZIA-Continued}

Crenata (Double Flowering). Double white flowers, tinged with rose. Blooms the middle of June. Two feet high when fully grown.

Gracilis (Slender-branched). A graceful and charming shrub, with pure white flowers. Blooms the middle of June. Two feet high when fully grown.

Lemoineii. A hybrid obtained by Mons. Lemoine of France, by crossing the well-known Deutzia Gracilis with Deutzia parviflora. F1owers pure white, borne on stout branches, of upright growth. Habit dwarf and free-flowering. A decided acquisition. (See cut on preceding page.)

Pride of Rochester, A varicty

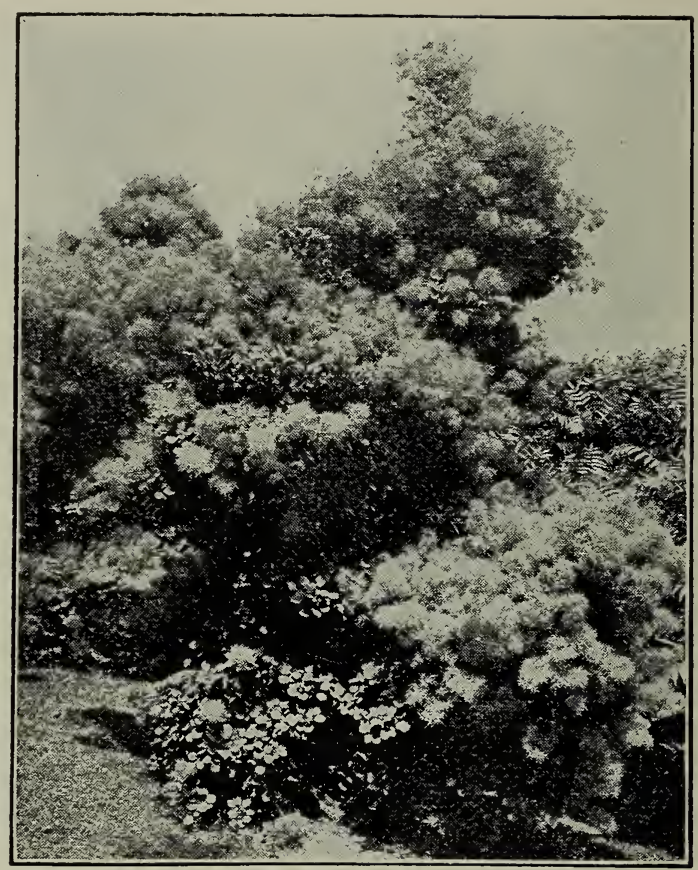

Purple Fringe raised by us and producing large, double white flowers, the back of the petals being slightly tinted with rose. It excels all the older sorts in size of flower, length of panicle, profuseness of bloom and vigorous habit; blooms nearly a week earlier than Deutzia Crenata.

\section{ELDER [Sambucus]}

Hardy, easily grown shrubs, and the new varieties are decidedly picturesque. They grow to be from five to six feet high.

Golden (Aurea). When they first appear the leaves are bright green, but if they have plenty of sun, they soon change to a golden green. The blossom resembles the common Elder bloom.

Variegated-Leaved (Variegata). A rapid-growing shrub, with foliage edged with yellow. Small white blossom. Blooms in June. Very beautiful.

\section{EXORCHORDA}

Grandiflora. A hardy, flowering shrub, of easy culture; a profuse bloomer in early summer, and its pure white flowers are borne in clusters. Will attain a height of from 10 to 12 feet and can be trimmed to any desired form.

FILBERT [Corylus]

Purple (Purpurea). A very conspicuous shrub, with large, dark purple leaves, distinct and fine. Is to shrubs what Purple Beech is to trees.

\section{FORSYTHIA}

Although not extensively planted, the Forsythias are worthy of attention. They make shrubs of about six to eight feet in height. Very beautiful yellow flowers cover the whole plant in early spring before the leaves appear. 


\section{FRINGE}

The Fringes are among the most popular and satisfactory large-growing slirubs.

Purple (Rhuscotinus). Also known as Purple Mist. Smoke Tree, and Smoke Plant. Covered during midsummer with loose panicles of curious hair or fringelike flowers, giving it a mist-like and novel appearance.

White (Chionanthus Virginica). A superb shrub, attaining a size of from 10 to 20 feet. Has a compact roundish form, large, glossy leaves, and drooping racemes of pure white flowers. Blossoms in May and June.

\section{HONEYSUCKLE-Upright [Lonicera]}

This species of shrub attains a height of from four to six feet.

Fragrant Upright (Fragrantissima). Dark, almost evergreen foliage; small, fragrant flowers, Blooms in May, before the leaves form.

Pink. A strong grower Pink flowers continue during entire season. Is a handsome and most desirable lawn shrub.

Red Tartarian (Tartarica rubra). A well-known sort. Blooms in May; bright, pink flowers.

White Tartarian (Tartarica alba). Like the preceding, except the flowers are a dull white color.

\section{HYDRANGEA}

Hills of Snow This magnificent hardy American shrub is the very finest addition to this class of plants found in many a year. The blooms are of the very largest size, of pure, snow-white color, and the foliage is finely finished. One of its most valuable characteristics is its coming into bloom just after the passing of all the early spring shrubs, while its long season of bloom from early June througl August renders it doubly valuable. Perfectly hardy, standing 20 degrees below zero.

Otaska. Foliage a deep green. Produces immense clusters of rose-colored flowers, in profusion during July; a very free bloomer. Should be planted in tubs, and stored in the cellar through the winter.

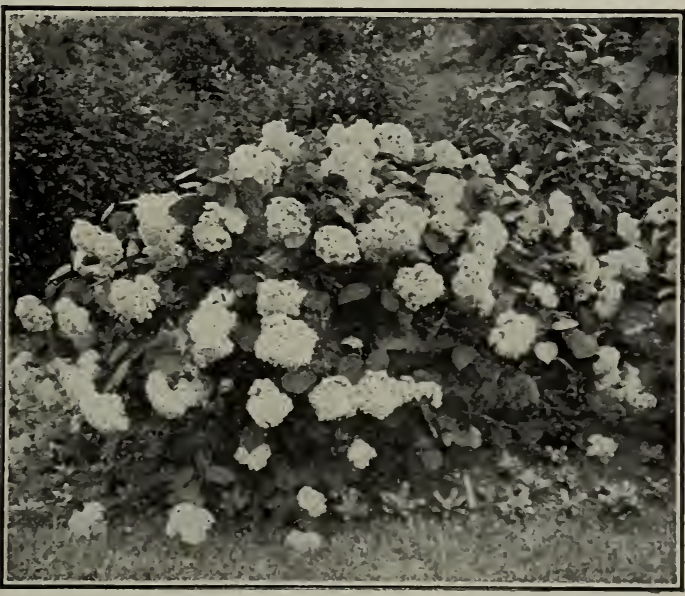

Hardy Hydrangea

Paniculata Grandiflora. Absolutely hardy; thrives in all soils; grows rapidly and blossoms profusely. Flowers are pure white, afterward clianging to pink, and are borne in large pyramidal trusses, often more than a foot long and six to eight inches in diameter. Begins to bloom early in August and continues in blcom for several weeks. Wherever known, it is conceded to be one of the finest flowering slirubs cultivated. It is equally valuable for planting singly or massing in beds. Should be headed in every Spring. Is grown in both slirub and tree form.

Thomas Hogg. May be planted in open ground, if slightly protected during Winter. Blossoms from July till September. Flower is pure white. Free blcomer. 


\section{LILAC [Syringa]}

Lilacs are well-known, hardy, free-blooming shrubs.

Chas. X. A strong, rapid growing variety; large shining leaves; trusses dark, rather loose, reddish purple.

Frau Dammann. Panicle very large; flowers of medium size and pure white; fine.

Giant Tree. This perfectly hardy variety from Japan makes a straight, stout, well-branched tree, 20 to 25 feet. The foliage is handsome and distinct. The clusters of small, creamy-white blooms are borne in June, after all other lilacs are out of flower.

Japonica. A species from Japan, becoming a good-sized tree. Foliage dark green, glossy, leathery; flowers creamy white, odorless, in great panicles. A month later than most varieties.

Lamarck. Flowers large; very double, large panicle; rosy lilac.

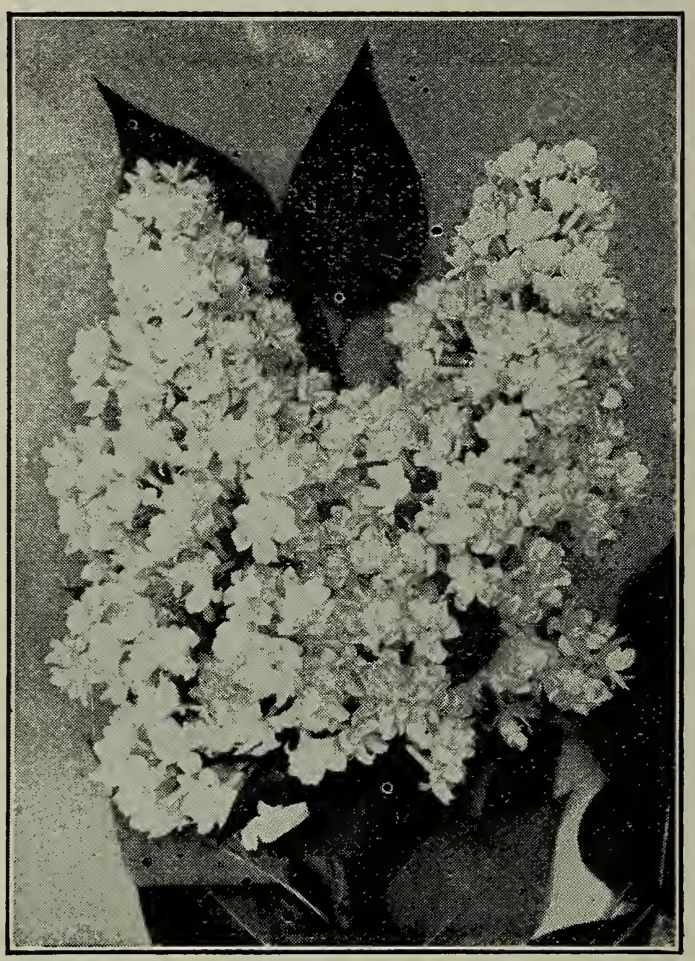

Lilac Lemoine

Large-Flowered White (Var. alba grandiflora). Bush similar in habit to the common purple variety; flowers white.

Lemoine. White

Leon Simon. Flowers very double, bluish; large trusses. A distinct and very showy variety.

Ludwig Spaeth. Panicle long; individual flowers large, single; dark purplish red; distinct; superb.

Marie Legrave. Large panicles, white fowers. Valuable for forcing. The finest white lilac.

Persian Purple. Attains a height of from four to six feet. Small foliage; flowers bright purple. A native of Persia, and a decided acquisition.

Persian Red. Grows four to six feet high. Small foliage and reddish flowers on large trusses. A very desirable and ornamental variety.

Persian White. Pure snow white flowers in profusion, fragrant and handsome.

President Grevy. A beautiful blue; individual flowers very double and very large; the panicle is magnificent. One of the finest lilacs.

Purple Common (Vulgaris). The old family favorite.

Villosa. A new Japanese species, with foliage resembling the White Fringe (Chionanthus), producing immense panicles of whitish or pale peach-colored flowers, blooming two or three weeks later than the English varieties. 


\section{PLUM [Prunus]}

Pissardi (Purple-leaved Plumi). Finest purple-leaved small tree or slirub. Leaves when young are lustrous crimson, changing to a dark purple, and retain this beautiful tint till they drop late in Autumn; no other purple-leaved tree or shrub retains its color like this. Flowers small, white, single, covering the tree.

Triloba (Double-flowered Plum). Native of China. Flowers double, of a delicate pink, upwards of an inch in diameter, thickly set on the long, slender branclies; flowers in May.

\section{RACEMOSUS}

A well-known shrub, with small, pink flowers, and large white berries that hang on the plant through part of the Winter.

SNOWBALL [Viburnum].

Common (Sterilis) A popular slirub. Makes a large bush. Bears balls of pure white flowers in June.

High-Bush Cranberry (Viburnum opulus). The well-known variety in old gardens. Grows eight to ten feet high, bearing its balls of flowers in great profusion in May, followed by scarlet fruit.

Japan (Viburnum plicatum). Of noderate growth, picturesque, compact habit; leares distinctly plicate or crinkled, and of a decidedly rich dark green; flower ball very solid, more white than the common variety; some weeks later, and remains on much longer. Perfectly hardy.

SNOWBERRY [Red fruited or Indian Currant. Coral Berry].

A shrub of very pretty foliage. Foliage, flowers and fruit small; fruit purple, hangs all winter.

\section{SPIREA}

Anthony Waterer. Makes a low, compact bush, covered nearly the whole season with umbels of deep crimson flowers. Desirable for massing or bedding, as well as for single specimens. Can be grown as a pot plant for house decoration.

Aurea. A striking variety, of decided beauty. The leaves are bordered with golden yellow, giving it a picturesque appearance, particularly in June, when the branches are covered with small double white flowers.

Billardi. Rose colored. Blooms nearly all Summer.

Bumaldi. A Japanese species, of dwarf, compact habit. Plant is covered during midsummer and Autumn with a mass of bright rose-colored flowers.

Callosa. Desirable because it blooms nearly all summer. Flowers are rose colored, borne in panicles. Very free grower.

Prunifolia. It begins to bloom in May, and the branches are corered for several weeks with pure white, daisy-like flowers. Very hardy. Of dwarf habit. One of the very best.

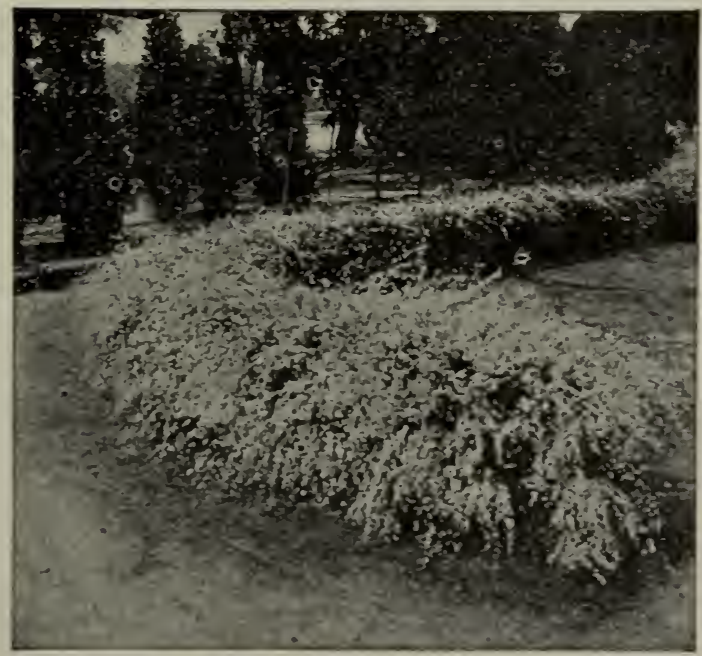

Spirea Prunifolia Hedge 


\section{SPIREA-Continued}

Reevesii. Narrow, pointed leaves. The flowers are white, quite large, borne in clusters, entirely covering the whole plant. Blooms in June.

Thunberg's. Of dwarf habit, and rounded, graceful form; branches slender, somewhat drooping; foliage narrow and yellowishgreen; flowers small, white, appearing early in Spring, being one of the first spireas to flower.

Van Houttei. An upright, graceful grower. The flowers a re pure white and are borne in dense clusters along the whole

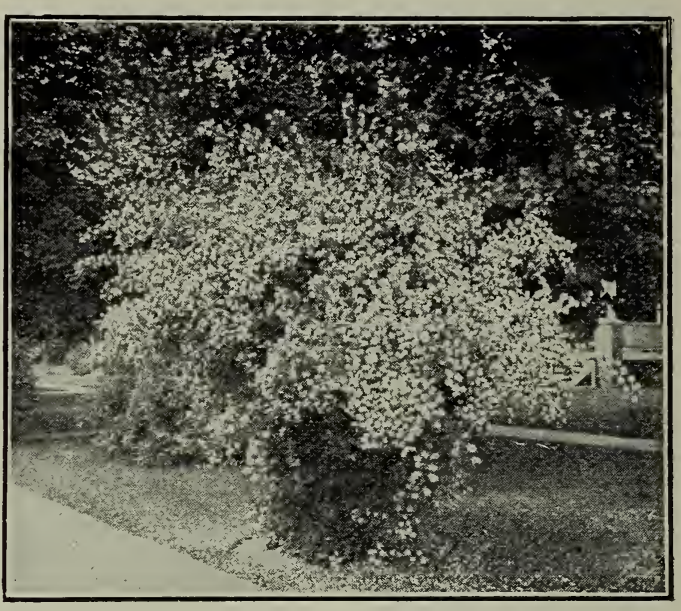

Spirea Van Houttei length of the branches.

\section{STRAWBERRY TREE [Euonymus]}

Also called Spindle Tree. A very showy shrub. Its chief beauty consists in its bright red berries, hanging in graceful clusters from the end of the branches. until midwinter. Grows to be from six to eight feet high.

\section{SYRINGA or Mock Orange [Philadelphus]}

Garland (Coronaria). A well known, hardy shrub; white, fragrant flowers. Blooms in June. Makes a large shrub.

Golden (Foliis aureis). The foliage is golden yellow, and retains its lovely color through the entire season. When set with other shrubs, the contrast is very pleasing. White flowers. Blooms in June. Very hardy.

WEIGELA [Diervilla]

The Weigelas are in every way desirable. They are easily grown, hardy and profuse bloomers. They make small shrubs.

Candida. A new and valuable acquisition. The flowers are of the purest white, blooming in June and remaining in bloom all Summer. It is hardy, an erect. and vigorous grower.

Desboisi. A variety with deep, rose-colored flowers, resembling Rosea, but flowers much darker.

Eva Rathke. Flowers brilliant crimson, a distinct and clear shade; a profuse bloomer. Very effective in borders and groups of trees.

Rosea. The best known sort. From China. Rose-colored, trumpet-shaped flowers. Blooms in June. Four to six feet.

Van Houttei. White flowers in clusters one inch in diameter.

Variegated (Foliis variegatis). Leaves bordered with yellowish-white, making the bush very conspicuous the entire season. Pink flowers, blooming in June. A very desirable shrub. 


\section{EVERGREEN SHRUBS}

\section{ASHBERRY [Mahonia]}

Holly-Leaved (Aquifolia) Bright yellow fowers in May; blush terries during the Fall; handsome foliage. Medium size.

BOX [Boxus]

Dwarf (Suffruticosa). The well-known sort used for borders.

DAPHNE CNEORUM [Garland flower]

A charming dwarf evergreen shrub, with glaucous green foliage; flowers bright deep pink, and fragrant. It begins to bloom in May and continues almost constantly until September.

\section{MOUNTAIN LAUREL}

Glossy green, shining foliage; flowers in large clusters, excellent sliape, and of a beautiful, delicate pink color.

\section{RHODODENDRON}

Rhododendrons are superb evergree $n \leq h r u b s$, prcducing dense clisters of magnificent flowers, but they require a somewhat shady situation and a peaty soil, free from lime. There are several colors, the most attractive being white, red and purple, all of which we can supply.

\section{TAMARIX}

African (Africana). Of great value for planting by the seaside. The fowers are small, borne in spikes in May.

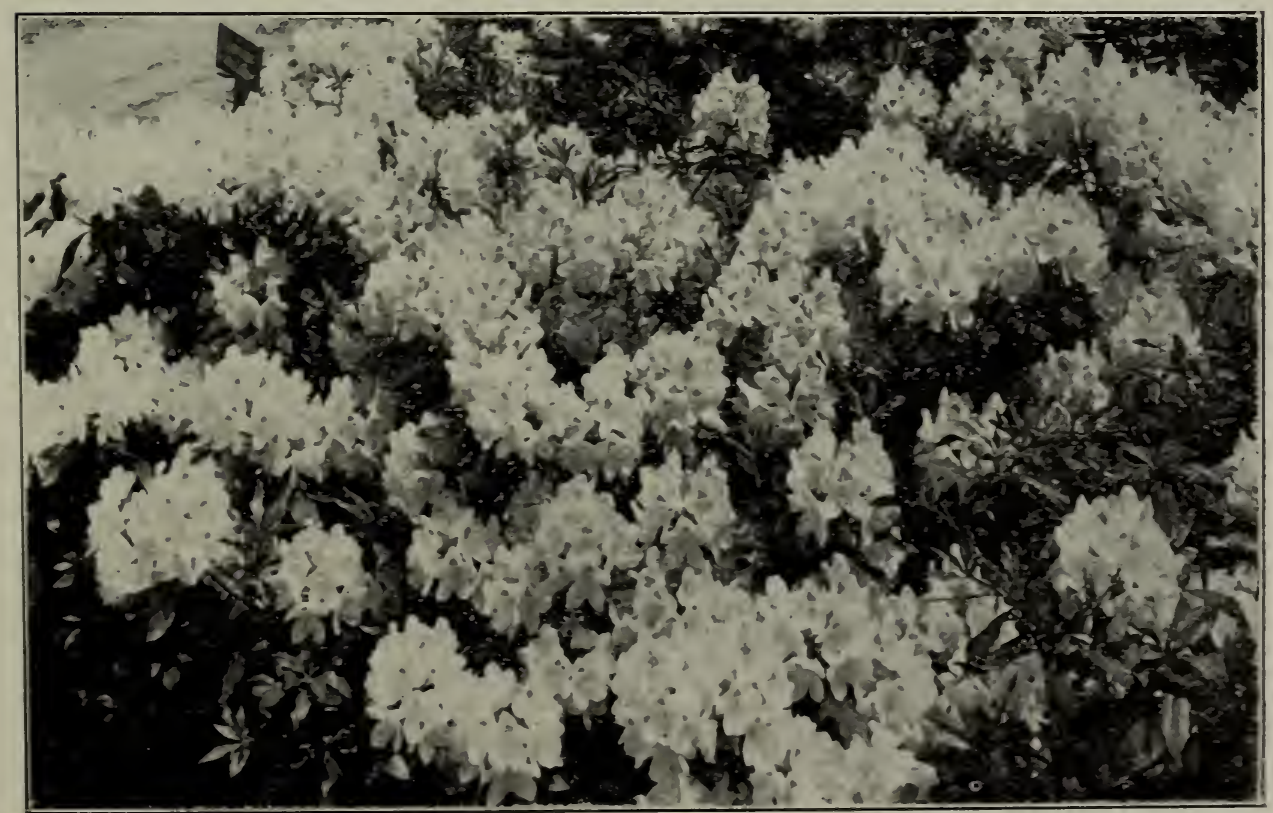




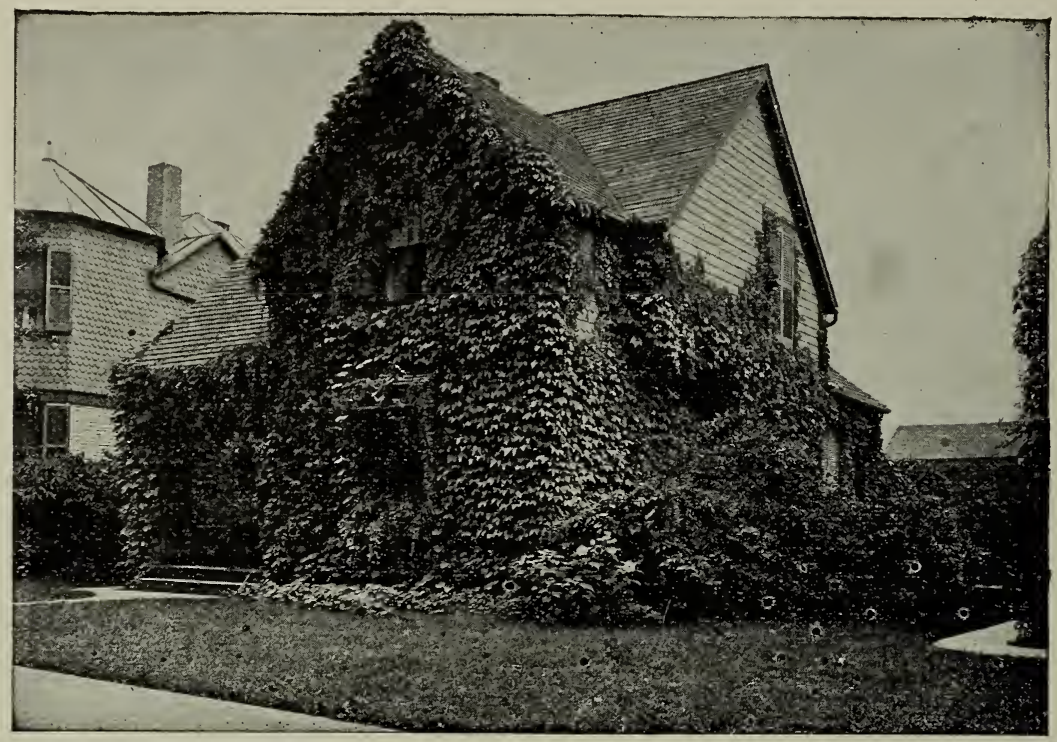

Ampelopsis

\section{HARDY CLIMBING VINES}

Ornamentals of this class are so hardy, so easily grown and so beautiful, that they deserve greater attention than they receive. No artist can produce pictures to equal the wealth of beauty displayed by the elegant Wistaria, the graceful Honeysuckle or the charming and magnificent Clematis when in the glory of full bloom. And there is nothing in art that will in any degree compare with the gorgeous hues of the Ampelopsis after it assumes its brilliant Autumnal tints.

\section{AKEBIA}

Quinta. A rapid-growing climber, with dark green leaves and purple flowers. Blooms in early Summer.

\section{AMPELOPSIS}

Veitchii (Veitch's). Leaves a little smaller and more ivy-like in form than American Ivy. Overlapping each other, they form a dense sheet of green. Plant requires a little protection the first winter until it is established, but after that it may be safely left to care for itself. It grows rapidly, and clings to the surface of even a painted brick wall with great tenacity. The foliage changes to crimson scarlet in Autumn.

\section{ARISTOLOCHIA, or Dutchman's Pipe}

Sipho. A rapid-growing vine with magnificent foliage, 10 to 12 inches in diameter, and curious pipe-shaped, yellowish-brown flowers.

\section{CHINESE MATRIMONY VINE}

A general utility hardy climbing vine that will overcome any obstacle to growth and flourish everywhere. Every new shoot produces handsome purple flowers, and later a prodigious crop of scarlet berries nearly an inch long. 


\section{CLEMATIS}

Clematis are pre-eminently the most showy and effective of the hardy, flowering climbing vines. All the varieties offered by us are entirely hardy, most of them are lavish bloomers, and the majority blossom the first season after transplanting. We deliver only a small root.

Duchess of Edinburg. This is without doubt the best of the double varieties; flowers pure white, deliciously scented.

Henryi. Fine bloomer; flowers large, of beautiful creamy white, consisting generally of from six to eight sepals. June to October.

Jackmanni. This is the variety upon which Mr. Jackman bestowed his name. It is better known than any jother, and still stands as one of the best. It is a strong grower, and produces a mass of intense violet purple flowers from June to October.

Kermesina Splendida. One of the most profuse bloomers of all the Clematis, commencing in early Summer and continuing through the season, literally covered with scarlet crimson flowers. Not subject to blight; a vigorous grower.

Lawsoniana. A continuous bloomer; flowers often five inches in diameter, opening a rich, glistening, rosy purple, gradually changing to a mauve purple.

Mme. Edward Andre. Flowers large, of a beautiful, bright velvety red; free flowering and continuous bloomer.

Paniculata. Perfectly hardy, and a rapid climber, producing a mass of pure white sweet-scented flowers, which are borne in long panicles and a ppear in August. The foliage remains fresh and green into early Winter.

Ramona. A new American seedling; strong, rampant grower, and very hardy. It is a free and perpetual blooming variety, botl on the old year's growth and on the wood of the current year. The color of the flower is deep sky blue and very at-

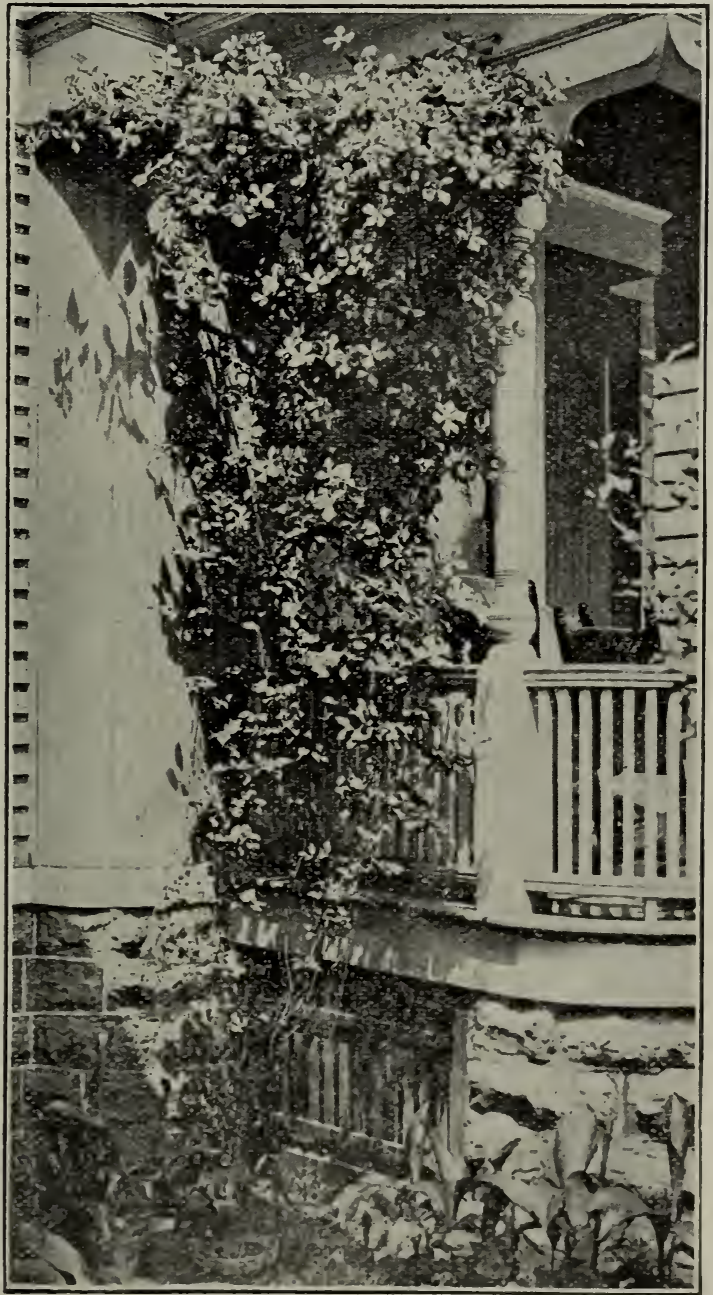

Clematis, Jackmanni tractive, five to nine inches in dianeter.

Rubella. Has the same continuous flowering liabit as the Jackmanni; flowers seven inches in diameter, commonly six sepaled; color a deep velvet claret, the ricli reddish flush giving it a distinct appearance. June to October. 


\section{DUTCHMANS'S PIPE.}

Sypho. A rapid growing vine, with magnificent foliage, 10 to 12 inches in diameter, and curious pipe-shaped, yellowish-brown flowers.

\section{HONEYSUCKLE [Lonicera]}

Hall's Japan (Halliana). A strong, vigorous, evergreen variety, with pure white flowers changing to yellow. Very fragrant. Covered with flowers from June to November.

Monthly Fragrant (Belgica). Blooms all Summer. Flowers red and yellow; very sweet.

Scarlet Trumpet (Sempervirens). A strong grower; and produces scarlet, odorless flowers all Summer.

\section{IVY [Hedra]}

The evergreen Ivies often suffer in Winter if exposed to the sun, and should therefore be planted on the north side of the wall or building.

American or Virginia Creeper, Woodbine (Quinquifolia). A very rapid grower, having beautiful, dark-green foliage, which assumes rich crimson hues in Autumn.

English (Helix). A well-known, old and popular sort.

Variegated-Leaved (Fol. variegata). With smaller leaves than the preceding, variegated with white.

TRUMPET VINE [Big. radicans] A splendid climber, vigorous and hardy, with clusters of large trumpet-shaped scarlet flowers. Blooms in August.

Bignonia Grandiflora. L e a ve s thick and shining, with immense blossoms of gorgeous crimson and yellow color.

WISTARIA [Glycine]

Chinese Purple (Chinensis purpurea). A very rapid grower, sometimes making 20 feet of wood in a single season. Bears long clusters of pale flowers in May and June and again in September. Extremely hardy. Attains a larger size than any other vine.

Chinese White (Chinensis alba). Habit of growth similar to Chinese Purple, but the flowers are somewhat smaller and pure white. Blooms in June and September.

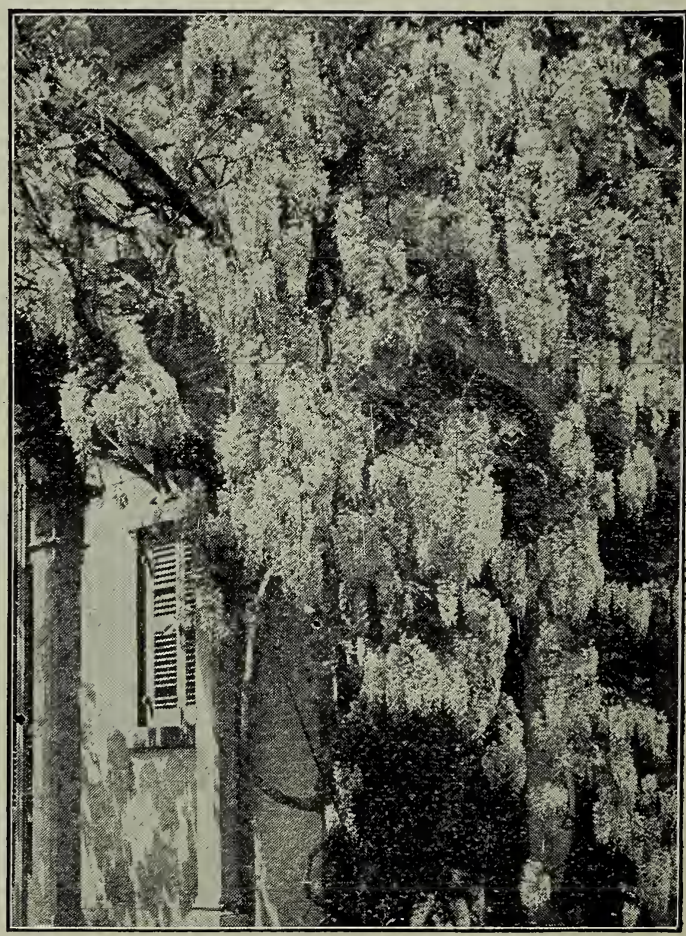

Wistaria, Purple 


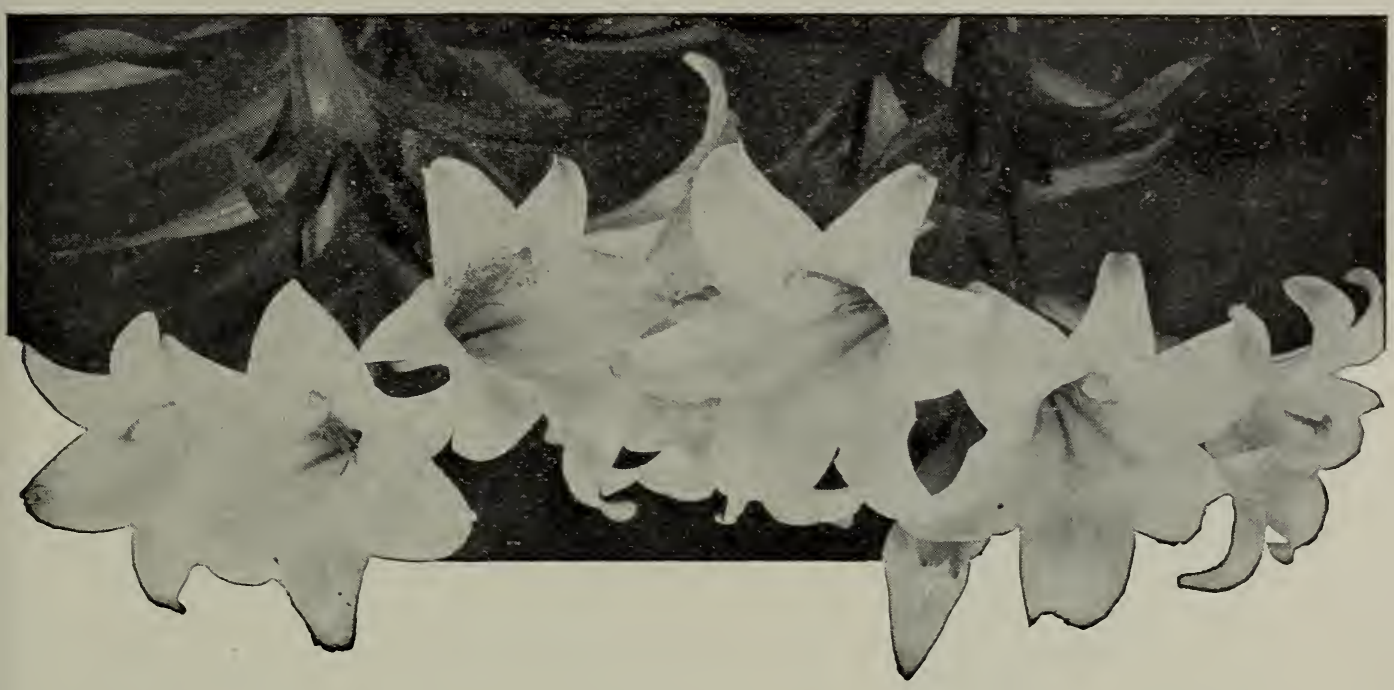

\section{Hardy, Herbaceous Flowering Plants and Bulbs}

The classes and varieties of bulbs are so numerous that limiterl space does not admit of our enumerating thein in this catalogue. Suffice it to say, we can supply anything in the bulbous line possessing merit and will be pieased to answer all queries regarding same.

\section{BULBS THAT MUST BE PLANTED IN THE FALL}

CROCUS These are delicate and tasteful in form and varied and gay in color. Until the flowering of the Hyacinth, and througl the most changeable and unpleasant of the Spring weather the garden depends almost alone upon the Crocus for its briglitness. Plant the bulbs in Autumn, about three inches apart, and cover with two inches of soil. Cover in Fall witl a little straw or coarse manure to keep the bulbs from being thrown out by the frost.

HYACINTHS An1ong all the bulbs used for Winter flowers, the Hyacinth stands foremost. Flowers nilay be produced by placing the bulbs in a glass filled with water or placed in pots or boxes in soil. For out-of-door culture, plant in the Fall three to four inclies below surface of soil and cover with straw or leaves before frost sets in. We can furnish in all colors, botlı single and double.

\section{NARCISSUS}

TULIPS We liave a splendid assortment of fine colors, both single and double. Early and late varieties prolong the season of bloon1.

\section{FOR FALL OR SPRING PLANTING}

We offer a fine assortment of the best varieties of these useful plants, whicli are exceedingly valuable on account of their hardiness, easy culture and showy appearance. Most of these will live all Winter iu the open ground and bloon freely every year. We nanie our leading sorts. 
ACHILLEA [Yarrow, or Milfoil]

The Pearl. Small, double wlite flowers, covering the plant in July. Invaluable for borders. One of the prettiest flowering plants and should be in every garden. One foot.

ANEMONE [Wind Flower]

Japonica Rubra. Red. Flowers two and one-half inches in diameter, bright purple rose with golden center, borne in great profusion from July to November.

Japonica Alba. White. A variety of the preceding; flowers pure white with a golden center.

Whirlwind. A variety producing double white flowers in great profusion in the Autumn. One of the finest Fall-flowering perennials. Hardy.

\section{DAHLIAS}

The Dahlia is the grandest Autumn flower we have; nothing is its equal in any respect in September and October. It is in its glory when everything else is faded or fading, and surrenders only to the frost. There are four generally recognized types - Single, or Cosmos-Flowered; Pompon, or Bouquet; Large Flowering, or Show; and Cactus.

\section{DAISY SHASTA}

A wonderful plant of the Daisy family, producing an abundance of beautiful white flowers. From two to five hundred blossoms in the season is the remarkable record.

DICENTRA, or Dielytra [Bleeding Heart]

Eximia. Rose color; foliage fern-like; flowers all summer; valuable; 12 inclies.

Formosa. Bright red flowers in May. Six inches.

Spectabilis. A handsome, curiously-formed, rosy-crimson flower, with white and blue tinged protruding stamen; one of the finest border plants; is quite hardy; well adapted for blooming in the winter; one to two feet. May and June.

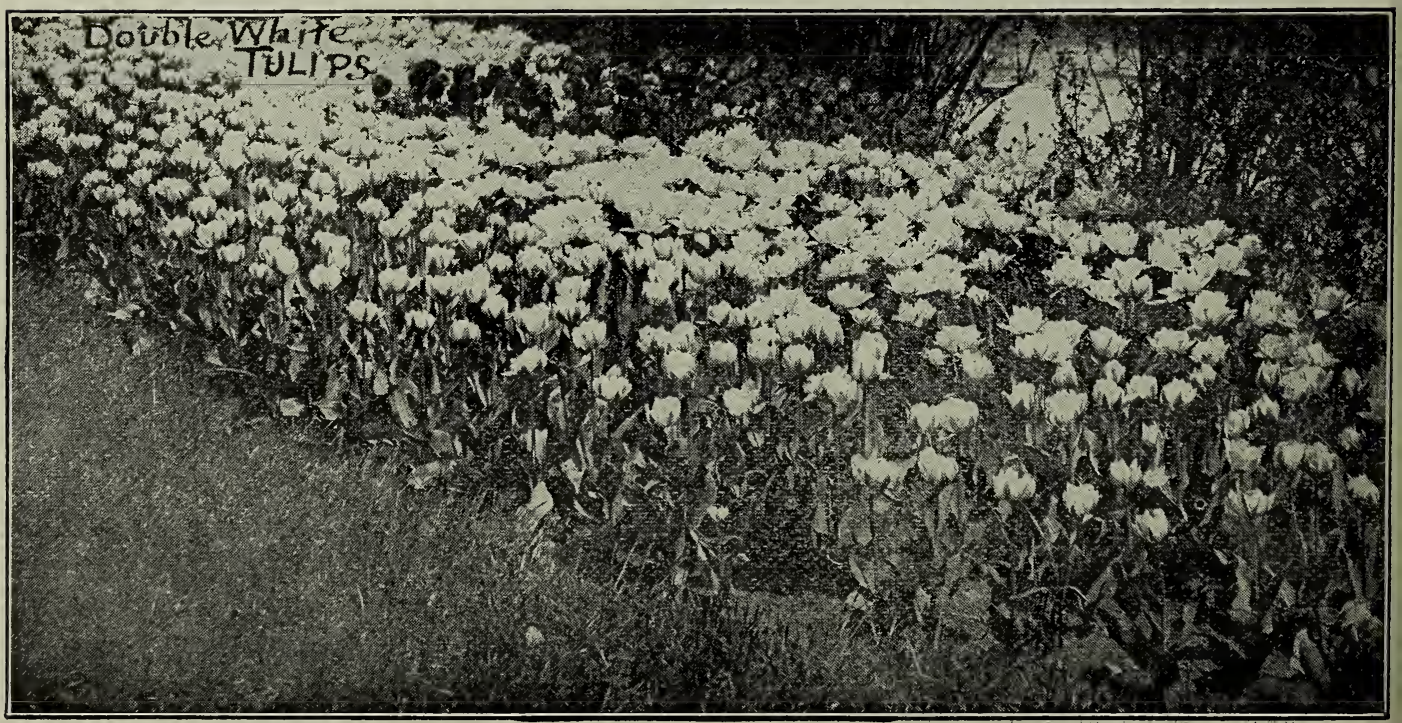




\section{EULALIA}

Grasses from Japan. Beautiful, hardy and deserving of the highest commendation. Invaluable for the garden, being very showy and easy of cultivation.

Variegata. Has handsomely variegated leaves. Four feet.

Zebrina. Zebra-striped Eulalia. One of the most beautiful of ornamental grasses; foliage marked crosswise with bands of white and green.

FUNKIA [Plaintain Lily]

A very interesting and beautiful genus, with luxuriant foliage. Invaluable for beds, border, rockwork, and marshy ground. Flowers and foliage distinctly beautiful. Will thrive in almost any position.

GAILLARDIA [Blanket Flower]

A genus of very ornamental hardy plants. Flowers yellow or purple, two inches across, single on naked stems. Very showy. Early summer until Autumn.

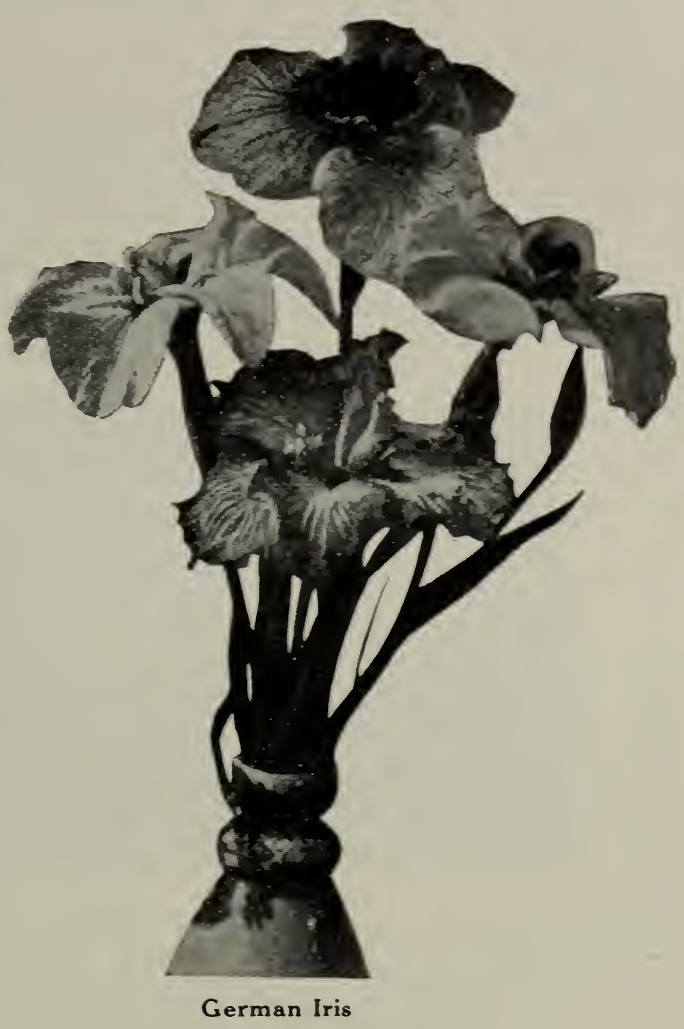

\section{GLADIOLUS}

Too well known to require description. No old-fashioned garden is complete without an assortment of Gladiolus. Attractive and easy of cultivation.

\section{GOLDEN GLOW}

This new flowering plant is hardy and an excellent grower. It blooms from July to September, and its double flowers are of a deep, golden-yellow color. In appearance they are like fine Chrysanthemuns and quite as attractive and desirable. We furnish only the root.

HEMEROCALLIS [Yellow Day Lily]

Often called J.emon Lily. Very fragant and one of the best.

\section{IRIS}

German. The true "Fluer de-Lis," the national flower of France. They are perfectly hardy, thrive anywhere, grow and bloon luxuriantly, particularly if plentifully supplied witl water or if planted in moist situations, as on banks of ponds, etc. Plants well established produce from 50 to 100 spikes of bloom, fragrant and fine for cutting. In beauty the flower rivals the finest Orchids, colors ranging through richest yellows, intense purples, delicate blues, soft maures, beautiful claret reds, white, primrose, and bronzes of every imaginable sliade.

Japan. Finest of all the Iris fanily. The flowers are of immense size, from six to eight inches in dianteter, and of the most beautiful and delicate sliades. They are perfectly hardy and flower in great profusion during June and July. A well established plant gives a dozen or more flower stalks two to three feet high, each stalk producing two to four enormous blooms. 


\section{LILIES}

'The Lilies should have a place in every garden, as they are entirely hardy, require little or 110 care and make a grand display. After planting they require little attention, and should not be disturbed for several years, as established plants bloom more freely than if taken up annually. We can furnish all of the leading varieties:

$\begin{array}{lll}\text { Auratum } & \text { Harrisii } & \text { Pardelinium } \\ \text { Candidum } & \text { Lancifolium } & \text { Tenuifolium } \\ \text { Elegans } & \text { Longiflorum } & \text { Tigrinum }\end{array}$

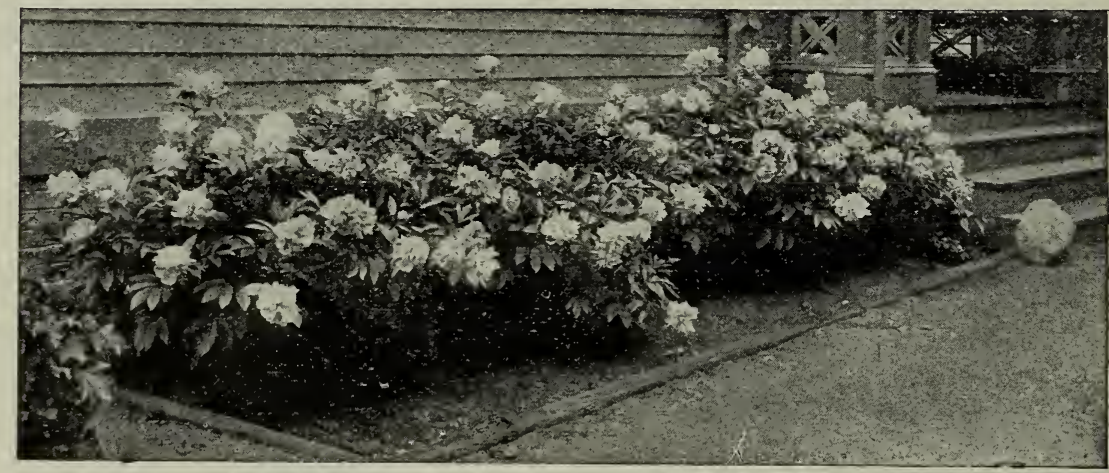

PAEONIES [Herbaceous]

Bed of Paecnies

It is surprising that so noble a flower, almost rivaling the Rose in brilliancy of color and perfection of bloom, and the Rhododendron in stately growth, should be so neglected. Amateurs seem to hare lost sight of the many improved varieties introduced within the last few years, and our finest gardens, perfect in cther respects, are singularly deficient in specimens of the newer kinds. They blossom early in June. Our collection has been made with great care and includes the best and most distinct varieties. We quote the fifteen most desirable.

Alba Superba. White, large and full.

Baron Rothschild. Outside petals rose, center salmon; sweet, distinct.

Caroline Mather. Purple crimson, very large, double and very dark.

Diamond. Large, white, fragrant.

Duchess de Nemours. Rose pink, very large, double, sweet; one of the best.

Festiva Maxima. Creamy white, with small center of carmine; round, early, in clusters, sweet.

Francis Ortegal. Dark purple crimson, very large, fine, deep, double and sweet.

Fringe-Leaved. The earliest-flowering variety, with deeply cut, fern-like foliage and dark crimson flowers.

Humei. Rose, full, large, late; one of the best.

La France. Pink outside, petals with yellowish center; very fine.

Rubra. Dark red; very early.

Triumph du Nord. Violet rose, lilac shade.

Variegated. Pink and salmon variegation, semi-double, sweet.

Victor Lemans. Rosy, light center.

Whitleii. Fine soft rose; extra large. 


\section{PHLOX}

These are annong the very slowiest and most valuable of all the liardy plants. They are of dwarf habit, perfectly hardy and easily cultivated. They yield a profusion of bright, showy bloon from July until late Fall.

\section{SELI BY NAME}

Amazon. Large flower, pure white.

Amoena. Flowers pinkisli purple, completely covering the plant in spring; one of the best flowering species.

Coquelicot. The best scarlet Plilox, unmatchable in color.

Carolina. Pink, showy flowers.

Flambeau. Briglit orange red, darker center.

Henri Murger. Pure white, large carmine center; flowers large.

Lothair. Rich salmon with crimson eye; showy.

Michael Cervantes. White with large rose eye.

Mme. P. Langier. Bright geranium red, vermillion eye.

Pantheon. Flowers large, pink, salmon, rose; distinct.

Procumbens. Lilac, with violet marks near the eye; three inches. May.

Richard Wallace. White with violet eye.

Sesostris. Large flower, bright carmine.

William Robinson. Pale salmon with rose center.

\section{POPPY}

Showy perennials with large flowers of rich and striking colors.

Oriental. Deep scarlet; large, very showy; 18 inches. June.

YUCCA [Spanish Bayonet--Adain's Needle]

Has a fine appearance. The stem is two feet above the ground, covered with creany white, bell-shaped flowers on laterals, forming a perfect pyramid; valuable for rock work.

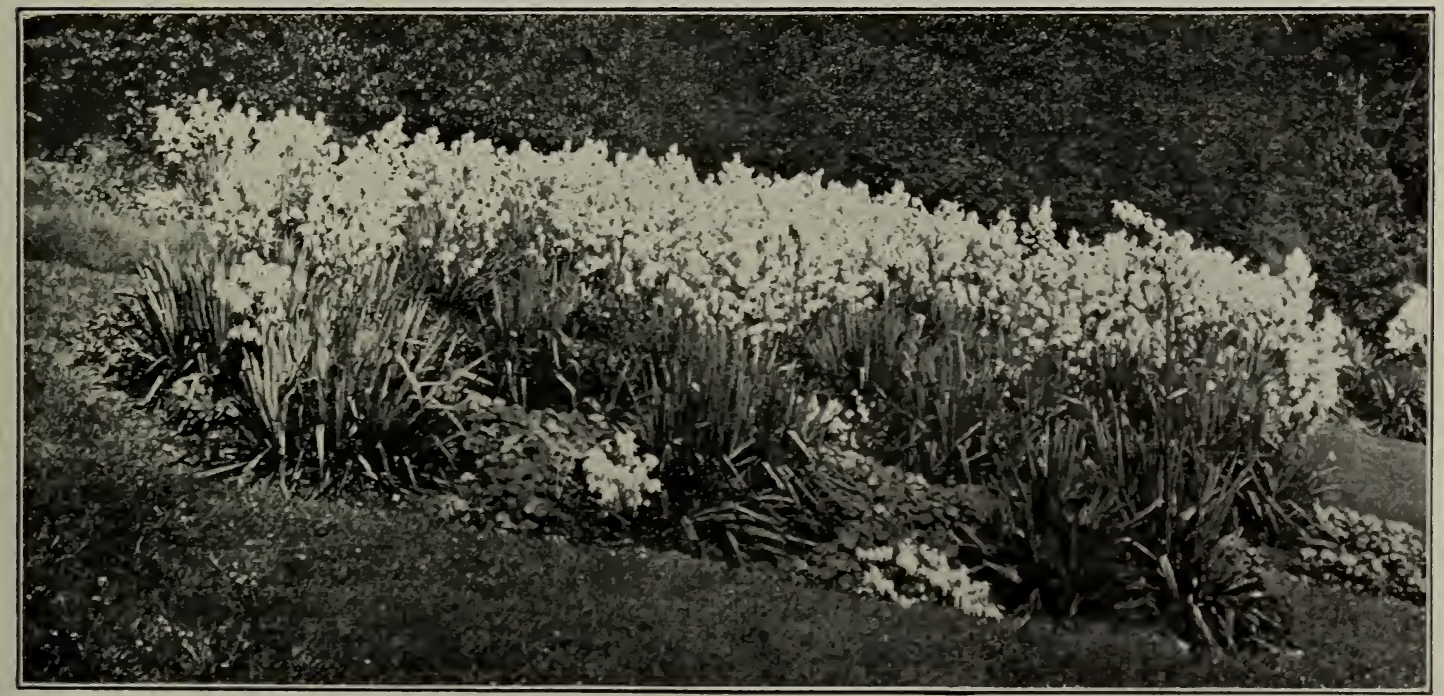




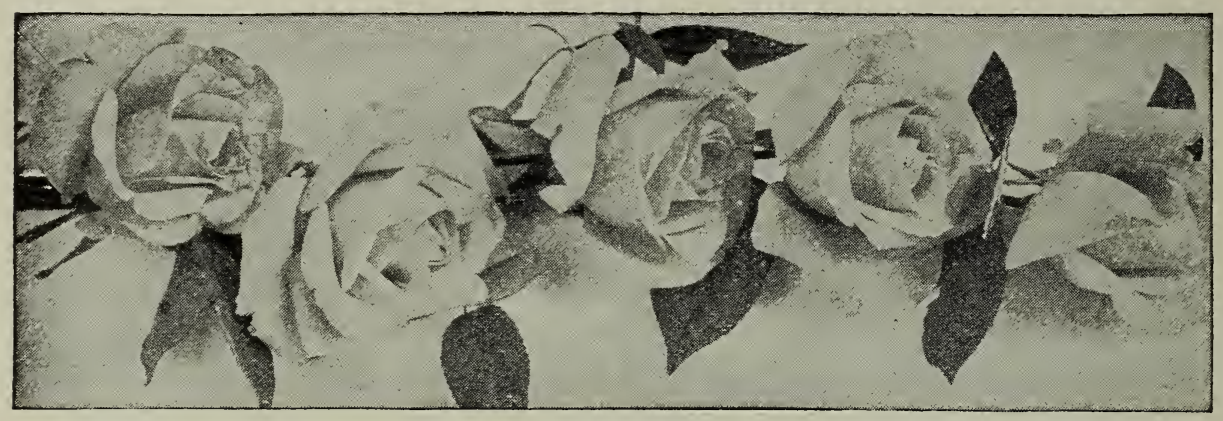

\section{HARDY, FIELD - GROWN ROSES}

Nothing that we say can add to the popularity of this most beautiful of all flowers. Those who appreciate the beauties of nature, prize roses above all things else in the ornamental line. While nearly all desire and perhaps make an effort to have an abundance of roses in their season, yet many fail, and the failure is usually due to planting inferior bushes, thousands of which are sent out over the country every year at a very low price. Our roses cost more than the weak, puny, hothouse plants referred to, yet the result shows that we give our customers as much for their money as any firm in the country. Our bushes are grown out of doors, in ordinary soil, and are as hardy and vigorous as it is possible to make them. When properly planted and cared for, they give perfect satisfaction.

While our list might be made much longer, we think it includes about all the desirable varieties. Roses are divided into four general classes-Hardy, Tender, Climbing and Moss. Those classed as Hardy include Hybrid Perpetuals or Remontants, those which usually bloom profusely during June and occasionally tlirough the Summer and Autumn; Austrian, those varieties of yellow roses which bloom but once in a season, and all other kinds which live out of doors without protection through the Winter. These are all suited for the garden and thrive the best in the open air. None of them require Winter protection. Those in the Tender class include Teas, Bourbons, Bengals or Chinas, Noisettes, and all of those sorts which are suited for either the open ground or house-culture, not named among the Hardy class. They are all tender and must be removed to the house during the Winter, although the Hybrid Teas can be left in the ground if they are protected by a covering of straw, leaves, evergreen boughs, or something of that kind. They do well in the garden during the Summer and, if planted in good soil, most of the varieties will bloom continually. The Climbing Roses are all hardy and should be planted out of doors. They bloom profusely in June and some varieties show an occasional blossom during the Summer and Fall. They are valuable for covering trellises, porches, rocks, etc. A1l of the Moss Roses are extremely hardy; most of them are very fragrant; they are excellent June bloomers, and some varieties bloom occasionally during the Summer and Autumn. The distinctive feature of the class is the "mossy" covering of the green outer leaves of the bud, which gives them an exquisite beauty to be found in no other rose. 
Abel Carrier $(\mathrm{H})$. Of better form and finish than most of the dark sorts. Color velvety crimson, with fiery center.

Alfred Colomb (H). Brilliant crimson. Very large, full and fine globular form; extremely fragrant.

American Beauty ( $T$ ). Large, globular; pink, sliaded with carmine; delicious odor.

Anna de Diesbach (H). Rosy carmine; large; very fragrant; good A utu un bloomer; vigorous grower; one of the very best.

Baby Rambler Crimson (H). Brilliant ruby-rose; foliage dark and glossy; blooms with the greatest freedom; hardy everywhere; steady and vigorous in growth, not being interrupted until after late frosts.

Baby Rambler Pink-Anna Mueller (H). Large clusters of brilliant rose-colored flowers in great profusion. A splendid bedding variety.

Baby Rambler White (H). One of the most charming roses in the Polyant ha class is this little rose. It continues to bloom all Summer througl with amazing freedom and fulness. Buslies candelabra shaped, and each branch bearing from 15 to 50 little flowers, creamy-white passing to snow-white. A truly charming rose and affords an abundance of flowers for cutting.

Blue Rambler (H). This new ram-

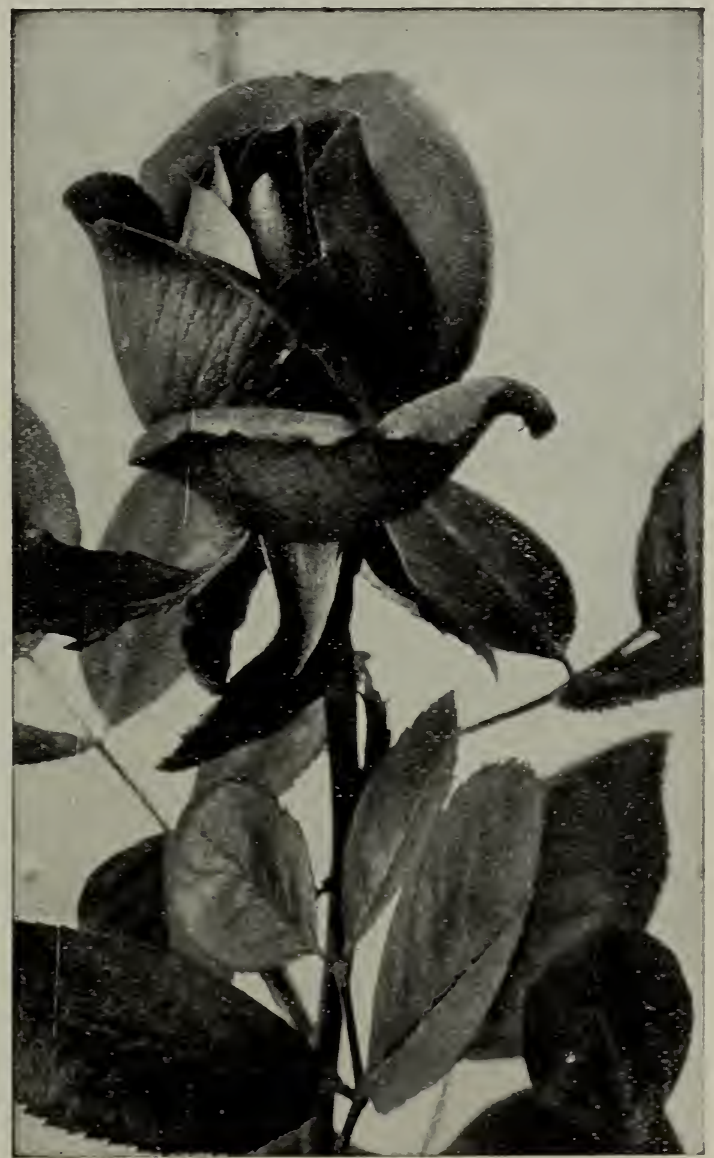

American Beauty

bler, which is hailed by the German rose growers as the forerunner of a genuinely cornflower blue rose, is a seedling of Crimson Rambler. 'The blossoms, massed in large umbels, are semi-double, of medium size. The color, on first unfolding. is either reddish pink or purplish pink, then turns amethyst, and finally steelblue as the flower fades.

Baltimore Belle (C). White with blush center; full and double; blccus in clusters; sliglitly fragrant; rapid grower; one of the liardiest and best climbers.

Baron de Bonstettin ( $\mathrm{H})$. Rich, velvety maroon; splendid sort.

Belle de Normandy (H). Color clear rose, sliaded and clouded with rosy carmine and lilac. Very large and double.

Blanche Moreau (M). White; elegant fcrm; great blocmer; strong grower; extra lardy; new, and gives promise of beconing innensely fopular.

Caprice (H). Satiny pink, daslied and flamed with white and carmine; blocms fieelya at short intervals during the season. 
Caroline Marniesse (H). Creamy white; flowers small and full, borne in pretty clusters; an exceedingly free bloomer; of dwarf habit and especially desirable for borders and for bedding. One of the most hardy of its class.

Climbing American Beauty (C). The favorite of all roses in climbing form.

Climbing Frau Karl Druschki (C). Flowers are white and of immense size and will make a most attractive pillar rose. Is vigorous and thrifty and one of the most valuable additions to our collection of climbers.

Climbing Victor Verdier (C). Brilliant carmine; very fragrant; hardy.

Clio $(\mathrm{H})$. Flower is perfection in form, with fine broad petals, high full center and is magnificent in all stages. Color delicate satin white, light shading of rosy pink in center. Plant a strong vigorous grower, with large, handsome foliage.

Coquette de Alps ( $\mathrm{H})$ White; blooms in clusters; fragrant; free blooner.

Crested Moss (M). Clear rose; beautifully crested buds; highly scented; extra fine.

Crimson Rambler (C). The plant is of very vigorous growth, making sloots of from eight to ten feet in a season. It may also be grown in bush form. The flowers hold their beautiful crimson color a long time, and give a most magnificent effect in contrast to the bright, glossy foliage. It is entirely hardy.

Dorothy Perkins (C). One of the liardiest of climbing roses. Remarkable vigor, often making a growth of from 10 to 15 feet in a single season. Like the Ran1blers in habit of growth and blooming, but the flowers are more double and of a beautiful sliell pink color. Sweetly scented, a characteristic not presented by other roses of the Rambler family.

Duc de Cazes (H). Extra large full flowers, double and sweet-scented. A beautiful shade of violet crimson; large and showy.

Earl of Dufferin (H). Rich, brilliant, velvety crimson, sladed with dark maroon; large, full, finely formed; delightful fragrance. A vigorous grower. One of the finest dark roses.

Empress of China (C). Commencesblooming early in June and continues until the ground freezes. Very fragrant; beautiful form; color deep red in the bud, changing to pink and red; nearly double, with a waxy appearance like a tea rose.

Excelsa (C). Very double; crimson maroon; flowers in large trusses.

Flower of Fairfield (C). A sport from the notable Crimson Rambler, which it re-

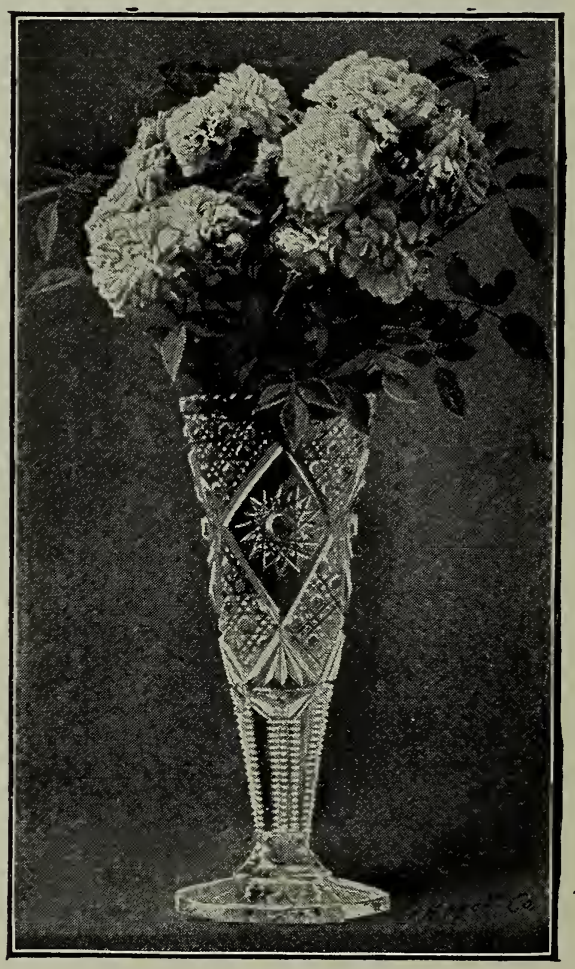

Dorothy Perkins sembles in every respect, except that in continues to blcom all summer, producing a marvelous succession of brilliant crimson clusters from Spring till late Autumn. A rose of great value.

Francis Levet (H). Color cherry red; flowers large size and well formed. A strong grower and a free bloomer. 
Frau Karl Druschki (H). Snowwhite; flowers of immense size and produced witl great freedom; very liardy and vigorous; usually strong growers, branching freely; buds egg sliaped, long and pointed. Usuaily admitted to be the hardiest white rose.

Gem of Prairies (C). Rich carmine; blooms in clusters; fragrant; strong grower; extremely hardy; one of the most desirable climbing roses.

General Jacqueminot ( $\mathrm{H})$. Briglit crimson, rich and velvety; buds are magnificent; flowers large and fragrant; desirable for open ground and forcing.

General Washington (H). Briglit, shining crimson; flowers large and double. Blooms almost consta11tly.

Gruss au Teplitz ('T). Dark, rich

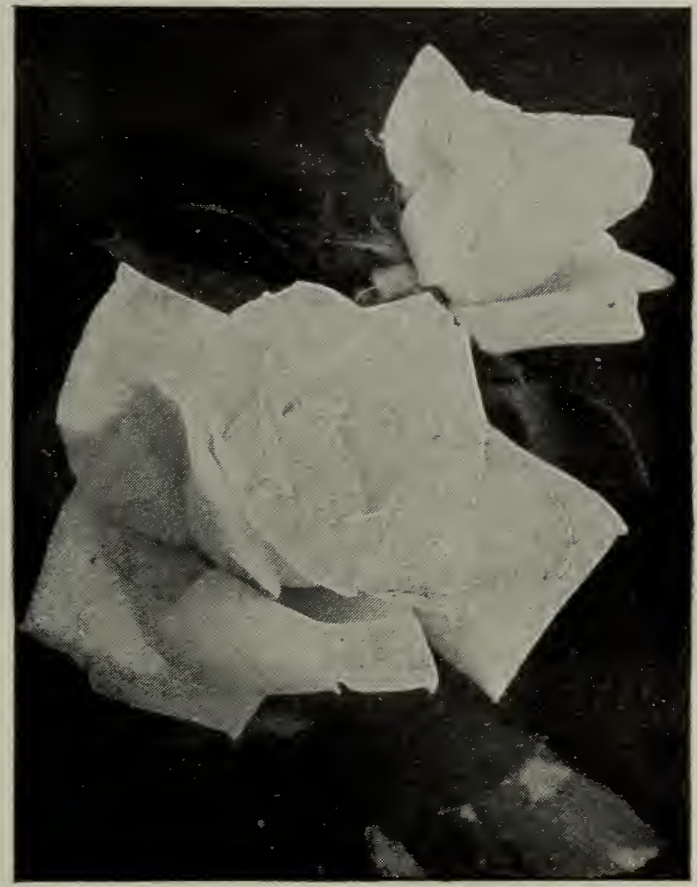

Kil'arney crimson, very bright flowers, large, full and sweet; bioons constantly, throwing up fresh buds and flowers during the whole of the growing season; healthy, hardy and vigorous.

Helene (C). A seelling of Crimson Rambler, possessing fully as rigorous habit as its parent and entirely hardy. The flowers are larger than those of the Crimson Rambler, nearly double, and borne in clusters of 20 to 5i). The color is a soft violet rose, base of petals yellowish-white. The anthgrs and pistils are pure yellow and so numerous as to give color to the flower.

Hermosa ( T). Bright blush; large; very double; cons!ant ulocmer.

Hugh Dickson $(\mathrm{H})$. 'The most remarkable addition to Rell II years. Vigorous growing; color brilliant crinson, slualed with scarlet; large and of fine form. Awarded gold medal of National Rose Society.

J. B. Clark (H). This new rose lias been sliown with flowers five to seren inclies in dianeter. Color is $11 \mathrm{ew}$, deep scarlet sliaded with darkest crimson. Fragrance is very sweet. Tluis is a wonderful variety.

John Hopper (H). Deep rose; very double; very fragrant. Iarge; good. Iate bloomer.

Jules Margottin (H). Cherry red; large; very double; fragrant; pretty buds. Free grower.

Kaiserin Augusta Victoria ( $T$ ). White, faintly blended with crean color; very large, full and double, almost perfect in form, and it continues beautiful eren when fully expanded. Very free flowering. Vigorous.

Killarney ('T). Color flesh, sliaded white, suffused pale pink flowors; large buds, long and pointed; and blooms profusely througlıut the season. Vigorous. 
Lady Gay (C). This new climbing rose originated in America. It is a perpetual source of wonder, yielding large trusses of pink flowers. Is a great novelty. Color is a deep, clear, rich, rose pink.

La France (H). Satin pink; splendid form; exquisitely perfunied; constant bloomer; none better. Requires Winter protection and high culture.

La Reine (H). Silvery peaclı; large; good form; fragrant; fine Autumn bloomer; vigorous grower. One of the most satisfactory roses cultivated.

Louis Van Houtte $(\mathrm{H})$. Bright rose carmine, full and very large. A

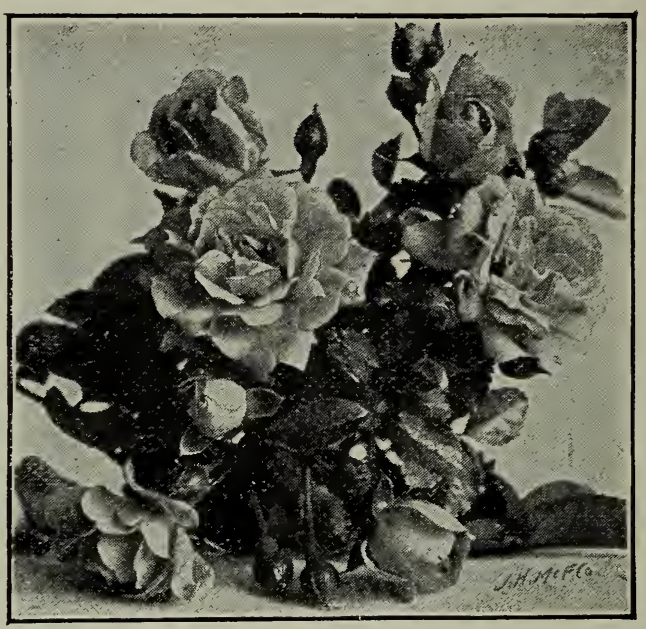

Lady Gay beautiful rose.

Mabel Morrison (H). White; very full and double cup-shaped flowers; petals firm and erect. A very valuable acquisition to any rose bed.

Mme. Gabriel Luizet (H). Beautiful pink; cup shaped; large, somewhat fragrant. exquisitely shaded, full and double; splendid. Vigorous grower.

Mme. Plantier (H). Pure white; full forn1; a profuse bloomer early in the season; free grower. One of the very best.

Mme. Vidot (H). Cream color; a semi-hardy tea rose; blooms profusely and is most desirable.

Mme. Alfred Carrier (H). Pearly white with slight pink tints in the center. An unusually strong grower and constant bloomer. Flowers of good size and handsome.

Magna Charta $(\mathrm{H})$. Bright, clear pink, fluslied with violet crimson; very sweet; extra large; fine form; very double and full; free bloomer.

M. P. Wilder (H). Flowers very large, perfectly double and of good substance. Color bright clierry red shading to crimson. Strong, healthy grower.

Marchioness of Londonderry (H). Flower of large size and perfect form, on stout, erect stems; color ivory white; petals shell shape; free flowering and highly fragrant.

Marechal Neal (T). Delicate yellow; exquisitely perfumed; lovely buds; has a climbing habit. A charming rose, but it requires careful treatment.

Margaret Dickson (H). Of magnificent forn1; white with pale flesh center; petals very large, shell shaped and of great substance; fragrant; foliage very large, dark green. A vigorous grower.

Memorial [H. Wichuraiana]

The growth is trailing or creeping, and can be used in covering terraces or tre1lises. They are hardy and grow well in the poorest soil. The foliage is thick and leathery, slining as if varnished, and keeps fresh and bright until nearly midwinter. The fowers are abundant and last in perfection for a long time. (For varieties see next page.) 
Memorial-Continued

MANDA'S TRIUMPH. The flowers are pure wlite and very double, producing clusters of from 10 to 12 on the small side shoots, literally covering the plant and standing well above the foliage.

Socth ORANge Perfection. Remarkably free flowering; about one and onehalf inches in diameter; soft blush pink at the tips, clianging to white.

UNIVERSAL FAYORITE. Flowers are very double, two inches and over in diameter, of a beautiful rose color; very fragrant.

\section{Moss Roses}

BLANCHE MIo:kAU. Pure white, large, full, and of perfect form; the buds and flowers produced in clusters and freely furnished with a deep green moss. A valuable variety. Vigorous.

Common Moss. Pale rose, very beautiful buds; a great favorite.

CRESTED Moss. Deep pink colored buds, surrounded with a mossy fringe and crest; free from mildew. A fragrant, very beautiful rose.

White BATH. White, sometimes tinged with flesh; attractive in bud and open flower. The best White Moss.

Mrs. John Laing (H). Color soft pink; flowers large, finely shaped and very fragrant; blooms late in the Autumn.

Paul Neyron (H). Shining pink, clear and beautiful; double and full; finely scented; free bloomer and one of the largest of roses, often measuring five inches across.

Perle des Jardins (T). Beautiful, straw color slightly shaded with canary; very large, full and of fine form; stiff shoots or stems and very free flowering.

Persian Yellow (H). Deep bright yellow; small but handsome. A very early bloomer. The finest hardy, double yellow rose.

Prince Camille de Rohan ( $\mathrm{H})$. Deep velvety crimson; large; fragrant; good bloomer; free grower. One of the finest roses cultivated.

Queen of Prairies (C). Rosy red; blooms abundantly in June; vigorous grower. One of the most hardy and desirable climbing roses known.

Rosa Rugosa [Japanese Rose]

Bushes when full grown, three to five feet; sturdy; covered with handsome glossy, green foliage and clusters of beautiful single flowers, which emit a delightful odor. Bloom throughout the Summer and are covered during the Autumn and Winter with red seed pods.

Rugosa RED. Beautiful, rosy crimson flowers.

Rugosa White. A remarkably free blooner, with flowers of purest white; delicate well formed buds.

Ruby Queen (C). Brilliant crimson or ruby red.

Soliel d'Or $(\mathrm{H})$. Orange vellow blended with reddisl gold and pink. Hardy everywhere; plants strong and robust; flowers large and globular.

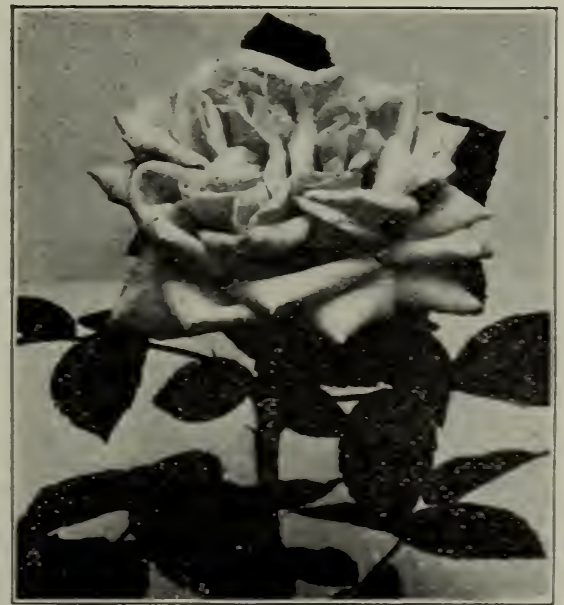

Soleil d'Or 
Souvenir de Malmaison ( $T$ ). Fawn color; fine form, continuous bloomer.

\section{Sweet Briars}

Amy RobSaRT. Lovely, d e e p rose; the bucls before opening are most graceful, of true Sweet Briar type; abundant bloomer; robust and free.

PENZANCE. Beautiful soft tint of copper with a peculiar metallic luster; the base of each petal a bright yellow; very free flowering, with delicious perfume from foliage and flower; a wonderful grower; shoots pendulous.

Lord Penzance. Soft shade of fawn or ecru, passing to a lovely yellow in the center, sometimes toned with a most delicate pink; a good grower and abundant bloomer; very sweet-scented.

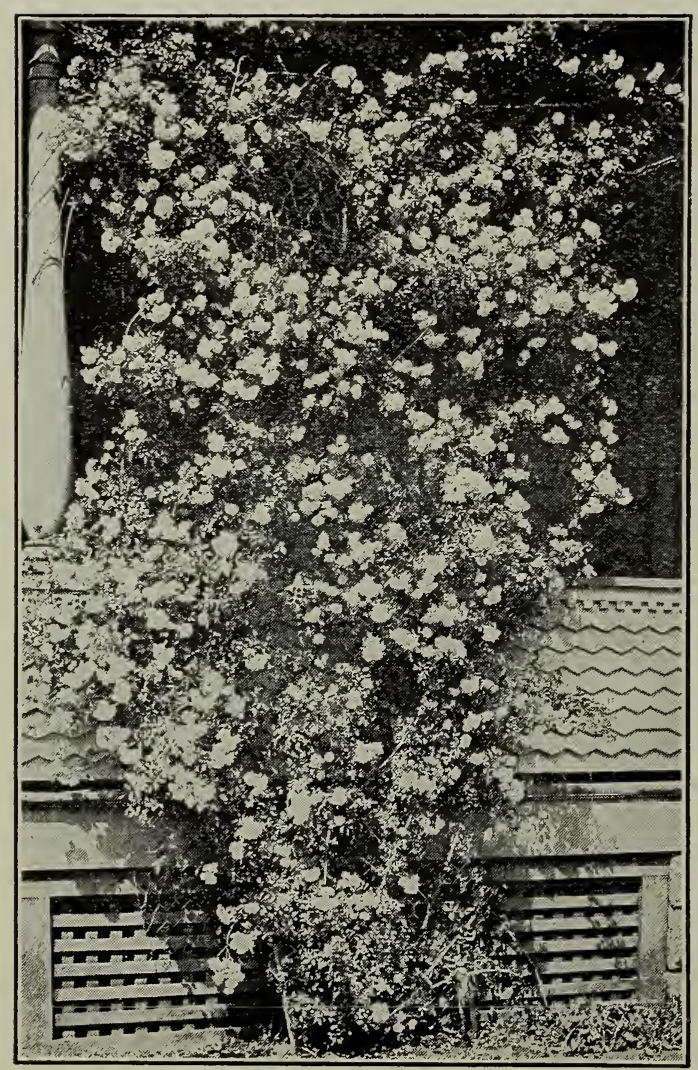

Excelsa, New Red Climber (See page 58)

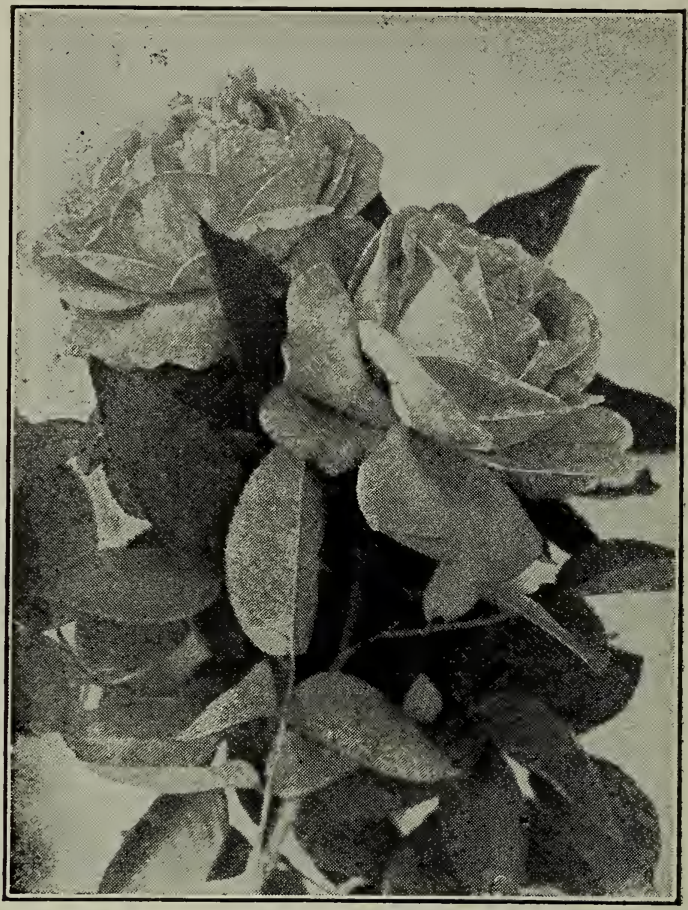

Mrs. John Laing (See page 61)

Tausendschon, or Thousand Beauties (C). Cannot be too highly recommended on account of free flowering qualities and beautiful white and delicate pink blossonıs. Has already been recognized by leading florists, and is grown in largequantities now for Winter forcing; for garden deccration it cannot be surpassed.

Victor Verdier (H). Carmine, purple shade; splendid Autumn bloomer; fine form. One of very best. Requires Winter protection.

Wedding Bells $(\mathrm{H})$. White, base of petals soft pink; very free flowering. Vigcrous.

White Rambler (C). One of Ramblers so rapidly grown in favor. Flowers well formed and, though small, produced in so great profusion as to present an immense mass of bloom.

Yellow Rambler (C). Growth habit similar to Crimson. Flowers in immense clusters; color a clear, decided yellow. One of the finest pillar or porch plants. 


\section{Insect Enemies and How to Destroy Them}

We embody herewith brief but plain descriptions of the various insects which attack different classes of trees and plants, and in each case the best known remedy. Our directions can be relied upon implicitly, and we need only ask our friends and customers to follow the directions to the letter.

\section{Directions for Preparing the Remedies}

Paris Green or London Purple - These poisons are used either in solution or dry form. In solution one pound is mixed with from 100 to 300 gallons of water, the strength depending on the plant sprayed and the insects to be destroyed. The poison should first be mixed with enough water to form a paste. after which the full quantity may be added. It is always best to add one or two pounds of lime for each pound of the green, as the danger to foliage will be much lessened thereby. Paris Green alone is sometimes applied in dry fcrm. It is best. however, to mix each pound with ten pounds of flour or plaster. The liquid is much less objectionable and we would in all cases recommend it.

Kerosene Emulsion-Take common bar soap, one-half a pound, water one gallon, and kerosene two gallons. Shave the soap into the water. then beat the whole till all the soap is dissolved; add the soapliquid, boiling hot. to the kerosene. and churn for 10 minutes by punping it back in to itself : when cool, the enulsion should have the consistency of thick cream or sof butter, this depending somewhat upon the kind of soap used.

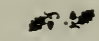

\section{Insects Affecting the Grape}

The Flea Beetle - This small. steel-blue insect appears in early Spring, and at once begins eating the tender foliage. After eating a short time the female heetle deposits small yellow eggs on the foliage. These soon liatch into small larvae, which continue the work of destruction.

Remedies - spray with Paris Green, one pound, and one and one-half pounds lime to 200 gallons of water. as soon as the beetles are noticed. Two applications of this solution at intervals of a weet or 10 days. will usually destroy all the insects.

The Rose Bug - It milkes its appearance early in the summer. devouring flowers, young fruit and leaves. The beetle is about half an incl long and of a hrown color.

Remedies - The best results have followed the use of Pyrethrum, which slould he applied in solution at the rate of one ounce to two gallons of water

\section{Insects Affecting the Apple}

The Coddling Moth-The little white caterpillar, whose effects are so familiar to everyone, is the larvae of a small, nocturnal, gray moth. The moth deposits her eggs on the blossom end of the fruit. As soon as the eggs hatch, the larvae eats its way into the young fruit; the rest of the story is well known to everyone.

Remedies - Spray the 1ree with Paris Green or London Purple at the rate of one pound to 250 gallons of water, add one and a half pounds of lime, first when the flowers are falling and again when the fruit is the size of peas.

The Canker Worm - This measuring worm eats the green portion of the leaf. giving the tree a brownish color, as though scorched by fire. The worms appear in early Spring, and when fully grown are an inch long.

Remedies - Spray the trees when the leaves are one-third grown, with Paris Green solution. one pound to 203 gallons of water, add one and a half pounds of lime. Usually one spraying will be sufficient, but if the worms appear to be on the increase a second application will be advisable.

Apple Tree Tent-Caterpillar-The large silken nests made by this insect are familiar to everyone. The caterpillars appear in May or June, and in five or six weeks have attained their full size.

Remedies - Cut out and burn the nests as soon as they are seen, taking the precaution to do this in the morning when the caterpillars are all in. This, together with one or two sprayings of Paris Green solution. liaving a strength of one pound to 200 gallons of water, and one and a half pounds of lime. will effectually rid the trees of tine pest.

The Apple Aphis - Apple trees are often attacked early in the season by this insect. The lice are quite small and green in color. By sucking the juices from the young growth they great$1 \mathrm{y}$ interfere with the functions of the latter. and as a result the tree has a sickly, yellow appearance

Remedies - spray with kerosene enulsion at the rate of one gallon to 20 of water, as soon as the lice appear. Repeat the treatnent in eight or ten days if necessary, A decoction made by soaking over niglit four or five pounds of tolacco stems. or refuse tolacco of any kind. in five gallons of water. will also be found an excellent remedy against the lice. 


\section{Insects Affecting the Currant and Gooseberry}

The Currant Worm-The perfect form of the worm is a small fly, which lays its eggs on the leaves in early Spring. As soon as the eggs As the worms increase in size, they become more voracious, often riddling the leaves.

Remedies - As soon as the worms are seen, spray the plants with a solution made by mixing one ounce of Hellebore in two gallons of water.

The Currant Aphis-The insect attacks The lice are usually abundant in early Summer, but as hot weather advances they disappear. hatch, the worms eat circular holes in the foliage. the leaves, causing them to curl and turn brown.

Remedies - Spray with kerosene emulsion, one gallon to twenty gallons of water. as soon as the lice are noticed.

\section{Insects Affecting the Rose}

The Rose Bug - The same as sometimes attacks the grape.

Remedies - The same.

The Green Aphis - The same that attacks the apple.

Remedies --- The same.

The Black Aphis -- The same that attacks the peach and other trees.

Remedies -- The same as for Green.

\section{SPRAYING}

Once a plant is attacked by disease it cannot be cured in the same sense that an animal can be. Spraying aims not to cure diseased plants but to protect them from two classes of enemies, insects and fungus (fungi, plural). The purpose of spraying is then to render plants immune against the insects or fungi to be feared. The spray mixture must be injurious to the enemies it is designed to forestall.

There are three main considerations in spraying. An effective spraying machine, one adapted to the character of the work; a mixture that will defeat the enemy; and a knowledge of the proper time to spray. The first can be secured through the manufacturers whose advertisements appear in fruit-growing magazines, the other two are explained in detail in the following paragraphs.

The principle underlying spraying is to cover the foliage or wood of plants with a medium in which the fungus will not grow, in the case of the plant parasite, or one which will poison the leaf-eating insect or kill the sucking insect by destroying its body. Both diseases and destructive insects work rapidly and a delay of a few days may make the remedy ineffective. Of all factors making for success in spraying, promptness is the most important.

We advise careful attention to these five points: (1) Know the enemy you are attacking; (2) study the remedy, its principles, how it acts; (3) secure the proper appliances for using the remedy; (4) prepare the spray mixture carefully; (5) apply it thoroughly.

\section{Ammoniacal Copper Carbonate}

\begin{tabular}{|c|c|c|c|c|c|}
\hline Copper Ca & nate & - & - & - & 5 ounces \\
\hline Ammonia & - & 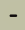 & - & & 2 quarts \\
\hline Water & - & - & - & - & 50 gallons \\
\hline
\end{tabular}

Prepare and keep in large bottles

\begin{tabular}{|c|c|c|c|c|}
\hline \multicolumn{5}{|c|}{ Arsenite of Lead } \\
\hline Lead Arsenite & & - & - & 1 pound \\
\hline Water & - & - & - & 150 gallons \\
\hline
\end{tabular}

\section{Arsenite of Lime}

This is much cheaper than Paris Green and equally efficient. It will not burn the tenderest foliage. Formula (for 800 gallons):

$$
\begin{aligned}
& \text { Arsenic, White - } \quad \text { - } \quad \text { - } \quad \text { - } \quad \text { - } 2 \text { pounds }
\end{aligned}
$$

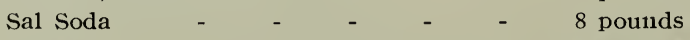

$$
\begin{aligned}
& \text { Water - - } \quad \text { - } \quad \text { - } \quad \text { - } \quad \text { - } 2 \text { gallons }
\end{aligned}
$$

Boil all together for 15 minutes or as long as it takes the arsenic to dissolve. The result is a concentrated solution that can be diluted as needed. One pint, together with two pounds of lime, added to a barrel of water, makes an insecticide as good as Paris Green. 


\section{SPRAYING CALENDAR}

EXPLANATION-While the number of applications recommended will be found desirable in seasons when the fungi are particularly troublesome, a smaller number may often suffice. WHENEVER AN ASTERISK $\left({ }^{*}\right)$ IS USED, it cautions against spraying with poisons while the plants are in blossom; A DAGGER $(\dagger)$ INDICATES that there is danger in making an application within three weeks of the time fruit is to be used.

\begin{tabular}{|c|c|c|c|c|}
\hline PLANTS & 1st Application & 2d Application & 3d Application & 4th Application \\
\hline $\begin{array}{l}\text { APPLE. Scab, cod- } \\
\text { lin moth. caterpil- } \\
\text { lar, canker worn, } \\
\text { bud motll. }\end{array}$ & $\begin{array}{l}\text { After blossoms } \\
\text { have formed, but } \\
\text { before they open, } \\
\text { Bordeaux. }\end{array}$ & $\begin{array}{l}\text { Within a week af- } \\
\text { ter blossons fall, } \\
\text { Bordeaux and Pa- } \\
\text { ris Green. }\end{array}$ & $\begin{array}{l}10 \text { to } 14 \text { days later } \\
\text { u se Boxdeaux } \\
\text { and Paris Green. }\end{array}$ & $\begin{array}{l}10 \text { to } 14 \text { days later } \\
\text { repeat }\end{array}$ \\
\hline $\begin{array}{l}\text { CHERRY. Rot, aphis, } \\
\text { curculio, slug, } \\
\text { kunt. }\end{array}$ & $\begin{array}{l}\text { As flower buds } \\
\text { appear, but before } \\
\text { they o pe } 11 \text {, Bor- } \\
\text { deaux; for aphis, } \\
\text { use Ke ros e ne } \\
\text { Enulsion. }\end{array}$ & $\begin{array}{l}\text { When fruit has } \\
\text { set. Bordeaux and } \\
\text { Paris Greell.* }\end{array}$ & $\begin{array}{l}16 \text { to } 14 \text { days later } \\
\text { if signs of rot ap- } \\
\text { pear, repeat. }\end{array}$ & $\begin{array}{l}10 \text { to } 14 \text { days. } \\
\text { Ammonical Car- } \\
\text { bonate of Copper. }\end{array}$ \\
\hline $\begin{array}{l}\text { CURRANT. Mildew, } \\
\text { worms. }\end{array}$ & $\begin{array}{l}\text { As soon as worms } \\
\text { are found on lower } \\
\text { and inner leaves, } \\
\text { use Paris Green. }\end{array}$ & $\begin{array}{l}\text { If they reappear, } \\
\text { repeat, adding Bor- } \\
\text { deaux for mildew. }\end{array}$ & $\begin{array}{l}\text { If worms still } \\
\text { trouble, Pyreth- } \\
\text { rum or Helle- } \\
\text { bore.* }\end{array}$ & $\begin{array}{l}\text { After the fruit is } \\
\text { picked, Bordeaux. }\end{array}$ \\
\hline $\begin{array}{l}\text { GOOSEBERRY. Mi } 1- \\
\text { dew, wormis. }\end{array}$ & $\begin{array}{l}\text { As leaves open Bor- } \\
\text { deaux and Paris } \\
\text { Green. }\end{array}$ & $\begin{array}{l}\text { In } 10 \text { to } 14 \text { days, } \\
\text { repeat with both. }\end{array}$ & $\begin{array}{l}10 \text { to } 14 \text { days later } \\
\text { Sulphide of Pot- } \\
\text { ash on English } \\
\text { varieties. }\end{array}$ & $\begin{array}{l}10 \text { to } 14 \text { days later } \\
\text { repeat. }\end{array}$ \\
\hline $\begin{array}{l}\text { GRAPE. F u } n g \text { g s } \\
\text { d is e a s e s, flea, } \\
\text { beetle. }\end{array}$ & $\begin{array}{l}\text { When first leaves } \\
\text { are ha } 1 \mathrm{f} \text { grown, } \\
\text { Bordeaux and } \mathrm{Pa} \text { - } \\
\text { ris Greell. }\end{array}$ & $\begin{array}{l}\text { As soon as the } \\
\text { fruit has set, re- } \\
\text { peat.* }\end{array}$ & $\begin{array}{l}10 \text { to } 14 \text { day's later } \\
\text { repeat. }\end{array}$ & $\begin{array}{l}10 \text { to } 14 \text { days later } \\
\text { if disease persists, } \\
\text { use Bordeaux. }\end{array}$ \\
\hline $\begin{array}{l}\text { PEACH, APRICOT. Rol, } \\
\text { mildew, leaf curl, } \\
\text { curculio. }\end{array}$ & $\begin{array}{l}\text { Before the blos- } \\
\text { sonis open, Bor- } \\
\text { deaux }\end{array}$ & $\begin{array}{l}\text { Within a week } \\
\text { after fruit has set, } \\
\text { use Bordeaux and } \\
\text { Paris Green.* }\end{array}$ & $\begin{array}{l}7 \text { to } 12 \text { day's later } \\
\text { repeat. }\end{array}$ & $\begin{array}{l}7 \text { to } 12 \text { days later } \\
\text { repeat. }\end{array}$ \\
\hline $\begin{array}{l}\text { PEAR. I,eaf - blight } \\
\text { scab, psylla, cod- } \\
\text { lin moth. }\end{array}$ & $\begin{array}{l}\text { Just before blos- } \\
\text { soms op p } 11 \text {, Bor- } \\
\text { deaux.* }\end{array}$ & $\begin{array}{l}\text { W it li i n a week } \\
\text { after the blossoms } \\
\text { fall. Boxdeaux and } \\
\text { Paris Green. }\end{array}$ & $\begin{array}{l}8 \text { to } 12 \text { day's later } \\
\text { repeat. }\end{array}$ & $\begin{array}{l}10 \text { to } 16 \text { days later } \\
\text { Bordeaux. }\end{array}$ \\
\hline $\begin{array}{l}\text { PLUM. Fungus dis- } \\
\text { eases, knot, curcu- } \\
\text { lio. rot. }\end{array}$ & $\begin{array}{l}\text { Within a week af- } \\
\text { ter blossoms have } \\
\text { fallen. Bordeaux } \\
\text { and Paris Green.* }\end{array}$ & $\begin{array}{l}10 \text { to } 12 \text { days later, } \\
\text { repeat. }\end{array}$ & $\begin{array}{l}10 \text { to } 20 \text { days later } \\
\text { Boxdeaux. }\end{array}$ & $\begin{array}{l}\text { If black knots are } \\
\text { found on plum or } \\
\text { clierry trees, cut } \\
\text { out; burn at once. }\end{array}$ \\
\hline $\begin{array}{l}\text { QUINCE. L e a f and } \\
\text { fruit spots. }\end{array}$ & $\begin{array}{l}\text { When bloss om } \\
\text { buds appear, but } \\
\text { before they open, } \\
\text { Bordeaux. }\end{array}$ & $\begin{array}{l}\text { When fruit has } \\
\text { set, Bordoaux and } \\
\text { Paris Green.* }\end{array}$ & $\begin{array}{l}10 \text { to } 12 \text { days later } \\
\text { repeat. }\end{array}$ & $\begin{array}{l}10 \text { to } 12 \text { days later } \\
\text { Bordeaux. }\end{array}$ \\
\hline $\begin{array}{l}\text { RASPBERRY and BLACK- } \\
\text { BERRY. A n t h r a c- } \\
\text { nose rust. }\end{array}$ & $\begin{array}{l}\text { Cut out canes badly } \\
\text { d is e a sed with } \\
\text { anthracnose a nd } \\
\text { burn. Before buds } \\
\text { open. spray with } \\
\text { Copper Sulphate } \\
\text { solution. }\end{array}$ & $\begin{array}{l}\text { When w e w canes } \\
\text { appear, Bordeaux } \\
\text { and Paris Green.* }\end{array}$ & $\begin{array}{l}10 \text { to } 14 \text { days later } \\
\text { repeat. }{ }^{+}\end{array}$ & $\begin{array}{l}\text { If red rust ap- } \\
\text { pears. grub ont } \\
\text { and burn the ent- } \\
\text { tire stool affected. }\end{array}$ \\
\hline ROSE. Worm, aphis. & $\begin{array}{l}\text { Kerosene Fnul- } \\
\text { sion for aphis. }\end{array}$ & $\begin{array}{l}10 \text { days later } 11 \mathrm{se} \\
\text { Bordeaux and } \mathrm{Pa-} \\
\text { ris Green. }\end{array}$ & $\begin{array}{l}\text { Afterwards keep } \\
\text { lice and caterpil- } \\
\text { lars off by turn- } \\
\text { ing a fine strean1 } \\
\text { from hose on nn- } \\
\text { der side of leaves. }\end{array}$ & \\
\hline
\end{tabular}

Do not spray with arsenite or copper compound within three weeks of the time the sprayed portions are to be eaten. While there would be no danger of fatal effects resulting, it is best not to run any risk. Bordeaux mixture and other lime compounds should not he used upon rough or full grown fruits even as late as that time. Not only dres the lime disfigure the fruit, but the amount of copper is large. 


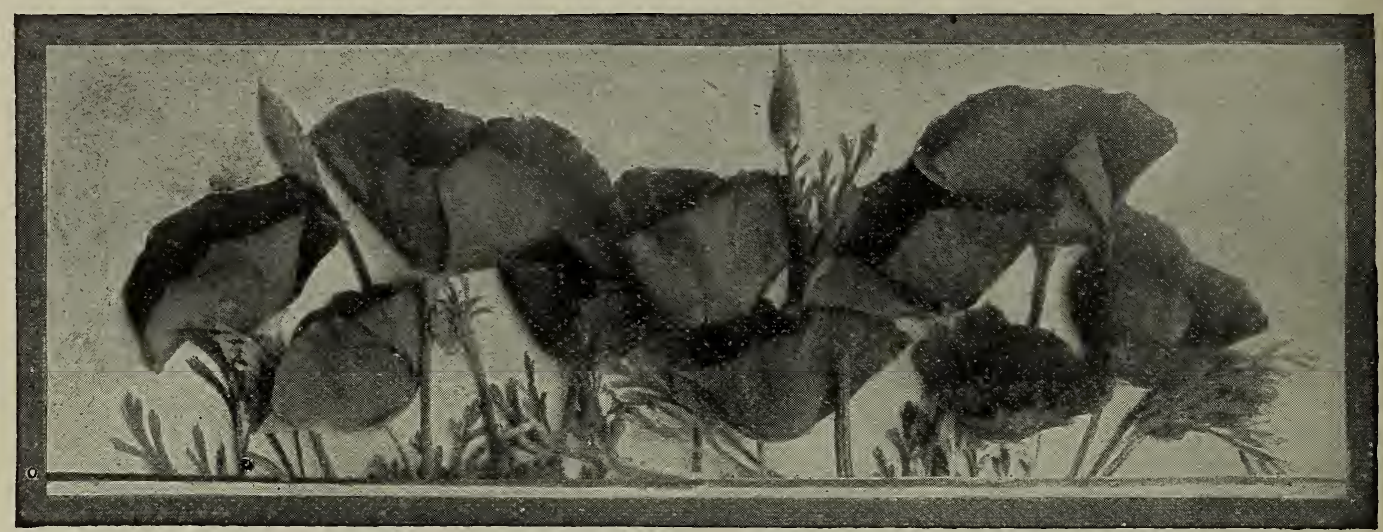

\section{HELPFUL GARDEN BOOKS}

\section{The Garden Primer}

By Grace Tabor. A hand-book of practical gardening information for the beginner. Every branch of gardening is covered in a delightfully practical way-vegetables and flowers, fertilizers, pruning, cultivating, spraying, etc. It is the one indispensable book for the gardening amateur. Illustrated from photographs. Bound in linen, $5 \times 7 \mathrm{~T} / 2$ inches.

\section{Price $\$ 1$ net; postage $10 \mathrm{c}$}

\section{Old Fashioned Gardening}

By Grace Tabor. This book tells of the gardens of the English cavalier gentlemen of Virginia, of the prim New England door-yards, of the Dutch housewives' gardens of New Amsterdam, of old. Spanish gardens of the Southwest, and finally it tells how to make gardens today that will be in keeping with the stately houses that have come down to us from the past. Illustrated.

\section{The Landscape Gardening Book}

By Grace Tabor. With this book as guide and counselor, the home, large or small, may be given that air of distinction that comes with the proper planting of trees, shrubs, flowers and vines, and the judicious laying out of walks and garden spaces. Valuable features of the book are the lists of plants for special purposes. Illustrations from photographs and diagrams. Bnind in linen, $71 / 4 \times 10$ inches.

Price \$2 net; postage 20c.

\section{Home Vegetable Gardening}

By F. F. Rockwell. An indispensable guide for en a man who does it. With this book's aid anyone can have a successful garden and an abundance of fine vegetables and fruit the first year. I1lustrated from photographs. Bound in dark green linen, $5 \times 7 \mathrm{~T} / 2$ inches. Uniform with The Garden Price $\$ 1$ net; postage $10 \mathrm{c}$

\section{Let's Make a Flower Garden}

By Hanna Rion. Here is the most charming book on gardening ever written-a broad statement, but you'll agree with it after you've read the book. It makes your hands fairly itch for a spade and a packet of seeds. The author's enthusiasm for her adventures in gardening is a refreshing: inspiration. Bound in linen, illustrated from photographs, with decorations by Frank Ver Beck, $5 \times 71 / 2$ inches. Price $\$ 1.35$ net; postage $14 \mathrm{c}$.

\section{GARDEN "MAKING" BOOKS}

Making a Rose Garden

By Henry H. Saylor. "The author has left nothing untold, the information ranging from the preparation of the soil to the culling of the flowers," says the "Pittsburgh Chronicle."

Making a Garden to Bloom This Year

By Grace Tabor. Here you may find directions for making a garden that will produce flowers this year. If you have procrastinated, here is the remedy-but don't put off getting the book.

\section{Making the Grounds Attractive with Shrubbery}

By Grace Tabor. There is a lot of money wasted in the hit-or-miss planting of shrubs. This book will save some of that money for you, and help you get them in right.

Making a Lawn

By Luke J. Doogue. Having a fine lawn means more than throwing a few handfuls of seed on the ground and waiting. This book tells the rest of the siory simply and succinctly.

\section{Making a Water Garden}

By William Tricker. The culture of pond lilies and other aquatics is one of the most interesting phases of gardening. It is far from difficult, if you use this book as a guide.

Making a Rock Garden

By H. S. Adams. There are some corners that re. quire flowers for their best appearance, yet at times the proper display is a matter of great difficulty, and the rock garden solves the problem.

\section{Making a Garden of Perennials}

By W. C. Egan. There may be reasons why you cannot plant new seeds and bulbs every spring. In this case the garden of perennials will be a great source of satisfaction. What kind of a garden and how to make it is told in detail.

\section{Making a Garden with Hotbed and Coldframe}

By C. H. Miller. As soon as amateur gardeners know how simple the management of two or three sash over a hotbed or coldframe is there will be a surprising extension of the garden's productive season.

\section{Making a Bulb Garden}

B y Grace

Tabor. The whole story of how most effectively to secure the earliest $\mathrm{s} \mathrm{pring}$ bloom as well as that from bulbs blooming throughout the summer and fall which well known.

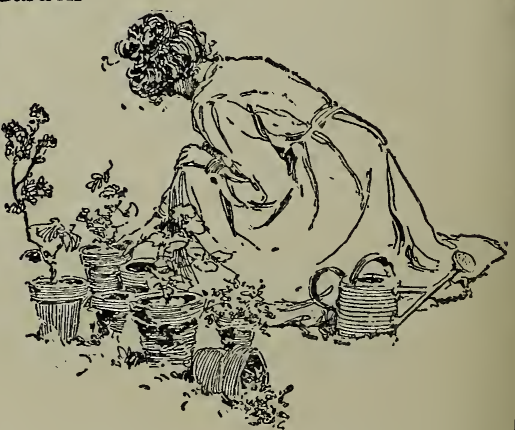




\section{N D E X}

\section{FRUIT DEPARTMENT}

Apples ...................... 3

Apricots ....................... 19

Asparagus ...................... 26

Blackberries .................. 25

Cherries..................... 12

Crab Apples.................... 8

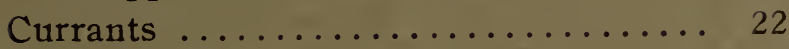

Gooseberries ................. 23

Grapes $\ldots \ldots \ldots \ldots \ldots \ldots \ldots \ldots \ldots, 20$

Horse Radish ................. 26

Mulberries.................... 19

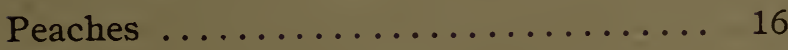

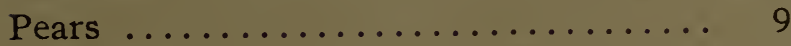

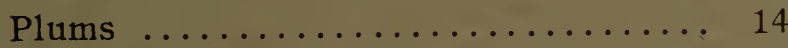

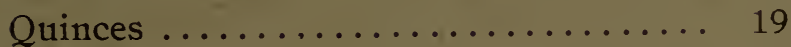

Raspberries ..................... 24

Rhubarb ......................... 26

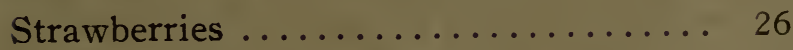

Walnut $\ldots \ldots \ldots \ldots \ldots \ldots \ldots \ldots \ldots \ldots \ldots \ldots \ldots \ldots \ldots$

\section{ORNAMENTAL DEPARTMENT}

Bulbs and Bulbous Roots ........... 51

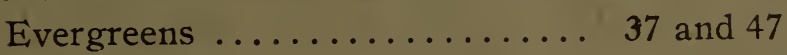

Hedge Plants .. ............... 39

Ornamental Trees ............... 27

Pæonies ........................ 54

Perennials .................... 52

Phlox ....................... 55

Rose Bushes ................. 56

Shade Trees.................. 27

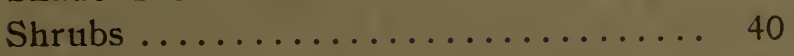

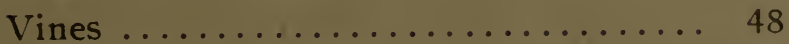

Weeping Trees ............... 35

MISCELLANEOUS

Books .................... 66

Spraying, etc................ 63 


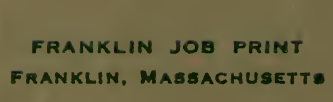

